\title{
THE CENTER AND THE PERIPHERY: TWO HUNDRED YEARS OF INTERNATIONAL BORROWING CYCLES
}

\author{
Graciela L. Kaminsky \\ Working Paper 23975 \\ http://www.nber.org/papers/w23975 \\ NATIONAL BUREAU OF ECONOMIC RESEARCH \\ 1050 Massachusetts Avenue \\ Cambridge MA 20138 \\ October 2017, Revised January 2019
}

I gratefully acknowledge support from the National Science Foundation (Award No 1023681), the Institute for New Economic Thinking (Grant No INO14-00009), and the SOAR Fellowship, IIEP, GWU. I want to thank Gianluca Benigno, Eugenio Cerutti, Andrés Fernández-Martin, Maria Luz Moreno Badía, Maury Obstfeld, Alan Taylor, Christoph Trebesch, and participants at the MCM Policy Forum (IMF), November 7, 2017; the Workshop of International Macro organized by the Research Institute for Development, Growth, and Economics (RIDGE) and the Central Bank of Uruguay, December 4-5, 2017; the Research Department Seminar (IMF), January 17, 2018; the Fiscal Affairs Department Seminar (IMF), January, 31, 2018; the 3rd International Macroeconomics and Finance Conference organized by Keio University in collaboration with Korea University, the Hong Kong University of Science and Technology, the University of British Columbia and the University of Tokyo, March 23-24, 2018; the InterAmerican Development Bank Research Department Seminar, May 17, 2018; the Barcelona GSE Summer Forum, June 18-19, 2018, Barcelona, Spain; Banco de España Seminar, June 20, 2018; the European Economic Association Annual Meeting, August 27-30, 2018, Cologne, Germany; the International Spillovers Conference organized by CEPR, the National Bank of Poland, the Central Bank of Lithuania, and CEBRA (Central Bank Research Association), Warsaw, Poland, September 20-21, 2018; the NBER IFM Meeting, October 26, 2018; the Annual International Macroeconomics and Finance (IFM) Meeting organized by CEPR, the National Bank of Belgium, and the Université Libre de Bruxelles, Brussels, Belgium, November 15-16, 2018; and the Econometric Society Annual Meeting, Atlanta, USA, January 4-6, 2019 for excellent suggestions. I thank Vida Bobic, Katherine Carpenter, Gabriel Fernandez, Samuel Mackey, Jeffrey Messina, Andrew Olenski, Pablo VegaGarcía, and Esteban Xifré-Villar, for superb research assistance. I also want to thank Stefano Banfi, Charles Collyns, Leonardo Hernández, and Diego Saravia for their help with the debt restructurings following the 1982 Debt Crisis and Julia Bersch and Angelo Riva for their help with the European Stock Markets in the 19th and early 20th centuries. The views expressed herein are those of the author and do not necessarily reflect the views of the National Bureau of Economic Research.

NBER working papers are circulated for discussion and comment purposes. They have not been peer-reviewed or been subject to the review by the NBER Board of Directors that accompanies official NBER publications.

(C) 2017 by Graciela L. Kaminsky. All rights reserved. Short sections of text, not to exceed two paragraphs, may be quoted without explicit permission provided that full credit, including (C) notice, is given to the source. 
The Center and the Periphery: Two Hundred Years of International Borrowing Cycles

Graciela L. Kaminsky

NBER Working Paper No. 23975

October 2017, Revised January 2019

JEL No. F30,F34,F65

\begin{abstract}
$\underline{\text { ABSTRACT }}$
A common belief in both academic and policy circles is that cyclical monetary policy in the United States increases the volatility of capital flows to the periphery. More recently, many studies on capital flows also focus on the U.S. Subprime Crisis. These studies emphasize the excessive international borrowing predating that crisis and the dramatic global retrenchment in capital flows in its aftermath. I re-examine these views using a new database I constructed of capital flows spanning two hundred years. Extending the study of capital flows to the first episode of financial globalization has two major advantages. First, during this episode, monetary policy in the financial center is constrained by the adherence to the Gold Standard, thus providing a benchmark for capital flow cycles in the absence of an active role of the central bank in the financial center. Second, panics in the financial center are rare disasters that need to be examined in a longer historical episode. The evidence from the new database indicates that capital flows to the periphery have become less volatile since the restart of globalization in the 1970s. But not all cycles are less pronounced, only those cycles around panics in the financial center. It is in times of crises at the epicenter that countercyclical monetary policy in the financial center is far more aggressive, with severe tightenings predating these crises and drastic easings in their aftermath. This policy cuts short capital flow bonanzas before these crises erupt and mitigates sudden stops in their aftermath.
\end{abstract}

Graciela L. Kaminsky

Department of Economics

George Washington University

Washington, DC 20052

and NBER

graciela@gwu.edu 


\section{Introduction}

The booms and busts in international capital flows since the restart of capital mobility in the 1970s have attracted a lot of attention in both academic and policy circles. Many suggest that capital flow bonanzas are excessive, end in crises, and lead to sudden stops. ${ }^{1}$ While the culprits behind the boombust cycles are many, the most frequently mentioned are the cycles of monetary easing and tightening in the United States (the world's financial center). It is further argued that these monetary cycles trigger highly synchronized international capital flows unrelated to countries' specific macroeconomic conditions, the so-called global financial cycle. ${ }^{2}$

Since the restart of financial globalization in the 1970s, there have only been three waves of capital flow cycles to the periphery: the one starting in the late 1970s, the one starting in the early 1990s, and the one starting in the early 2000s. Thus, the empirical research on the role of monetary policy in the financial center on international capital flow cycles to the periphery focuses at most on the easingtightening cycles around these three episodes. With just three waves of capital flow cycles, it is hard to pinpoint the role of monetary policy in the financial center on the rest of the world. This is especially so because these capital flow cycles coincide with other worldwide shocks, such as the oil shocks of the 1970s, the creation of the European Monetary Union in the 1990s, and the savings glut in East Asia in the early 2000s.

Another aspect of booms and busts in capital flows that has attracted attention more recently is the role of crises in the financial center. Many have pointed to the global retrenchment in capital flows in the aftermath of the Subprime Crisis in the United States. ${ }^{3}$ This slowdown in international borrowing has been accompanied by a protracted collapse in the global economy quite different from the one following previous capital flow bonanzas and busts. While the boom-bust borrowing cycle in Latin America, Asia, Russia, and Turkey in the 1990s also ended with crises, those crises were short-lived with the periphery rapidly rebounding. Importantly, those crises erupted amid highly liquid international capital markets with a healthy financial center and a growing world economy, with vulnerabilities only present in the crisis countries. In contrast, the crisis starting in 2007 had the financial center at its epicenter, with international capital markets collapsing and the world economy coming to a standstill.

\footnotetext{
${ }^{1}$ See, for example the IMF World Economic Outlook (2016]; Broner, Didier, Erce, and Schmukler [2013]; Calvo, Leiderman, and Reinhart [1993]; Cerutti, Hale, and Minoiu [2015]; Forbes and Warnock [2012]; Ghosh, Qureshi, Kim, and Zalduendo [2014]; and Reinhart and Reinhart [2009].

2 See, for example, Rey [2015].

${ }^{3}$ See for example, Boussière, Schmidt, and Valla [2016] and Milesi-Ferretti and Tille [2010].
} 
Importantly, it is hard to draw general conclusions about crises with the financial center at its epicenter from just examining the crisis of 2007-2008.

In this paper, I study international capital flow cycles during a far longer episode. I look at the first episode of financial globalization (starting with the end of the Napoleonic Wars in the early $19^{\text {th }}$ century and ending with the Great Depression in 1931 when barriers to international capital flows and trade are erected around the globe) as well as the second episode of financial globalization (beginning with the collapse of the Bretton Woods System in the 1970s). Studying the dynamics of capital flows during these two episodes has two major advantages. First, during the first episode of financial globalization, monetary policy in the financial center is constrained by the adherence to the Gold Standard, providing a benchmark for capital flow cycles in the absence of an active role of the central bank in the financial center. Second, panics in the financial center are rare disasters. ${ }^{4}$ Thus, to understand the empirical regularities of this type of global crises, we need to look at a longer historical episode. The first episode of financial globalization spanning more than 100 years is witness to major crises in the financial center, such as the London panic in 1825, the world crisis in 1873 fueled by the collapse of financial markets in continental Europe, the 1890 Baring crisis in London, and the crisis following the collapse of financial markets in London and New York in 1929.

To study capital flow booms and busts since the start of financial globalization in the early $19^{\text {th }}$ century, I constructed a new database of international capital flows spanning two hundred years. The data for the first episode of financial globalization was collected in London, Paris, Berlin, Frankfurt, and New York, the financial centers of the $19^{\text {th }}$ and early $20^{\text {th }}$ centuries. I used information in archives, prospectuses, annual reports of the Stock Exchanges, and financial newspapers of those times. The database includes public international issuance (central governments, provinces/states, and municipalities) as well as international issuance by private financial and non-financial firms. The database is granular. It includes data on every bond and share floated in international capital markets. For bonds, it includes the amount issued, the interest rate, the issue price, the amortization characteristics, the underwriting banks, as well as information on the markets where those bonds were floated. For shares, the database includes the amount issued, the price of issue, whether shares are ordinary or preferred, as well as the markets were those shares were issued. ${ }^{5}$ I constructed a similar database for the second

\footnotetext{
${ }^{4}$ See Barro [2006].

${ }^{5}$ This database is the first comprehensive database on international capital flows for the first episode of financial globalization. This is an important contribution of this paper since while there is partial historical data on central government external debt there is no information on private external borrowing and debt. Stone [1999] constructed international capital flows using issuance of bonds and equity in London from 1865 to 1914 for twenty-one countries.
} 
episode of financial globalization beginning in the 1970s. The database for the 1970 s is collected from the archives of the World Bank while the data starting in 1980s is from the IMF, the Institute of International Finance, Central Banks, as well as from various digital databases. The database constructed for the second episode of financial globalization is also granular and includes all the bonds, syndicated loans, and shares floated in international capital markets. The database on international issuance is complemented with a database on economic fundamentals, including economic activity, commodity prices, terms of trade, world interest rates, inflation, and monetary statistics in the financial centers, all going back to 1820.

This paper focuses on capital flows to Latin American countries. I concentrate on the seven most active participants in international capital markets: Argentina, Brazil, Chile, Colombia, Mexico, Peru, and Uruguay. These countries start to participate in international capital markets right after their independence from Spain and Portugal in the first twenty years of the $19^{\text {th }}$ century. I study the characteristics of booms and busts in international gross primary issuance for each Latin American country, with a focus on duration and amplitude. For each cycle, I calculate the increase in indebtedness using the information on primary gross issuance and the amortization characteristics of bonds and loans as well as the effects of conversions, defaults, and restructurings. I classify capital flow cycles into two varieties: Systemic Capital Flow Cycles and Idiosyncratic Capital Flow Cycles. Systemic Capital Flow Cycles are those issuance cycles in the periphery that are around a crisis in the financial center. There are six major financial panics in the financial centers in this two-hundred-year episode: four of those during the first episode of financial globalization (the already mentioned London 1825 panic, the 1873 panic centering in continental Europe, the 1890 Baring crisis, and the 1929 panic in London and New York) and two during the second episode of financial globalization (the Banking Crisis in the United States starting in 1981 and the U.S. Subprime Crisis beginning in 2007). Idiosyncratic Capital Flow Cycles are identified as those cycles unrelated to panics in the financial center. The characteristics of these cycles are then compared across the two episodes of financial globalization. Finally, I study the effects of economic and financial shocks (both country-specific and global) on booms and busts in international borrowing by the emerging periphery.

The main results of the paper indicate that:

Unfortunately, this database lacks information on the individual issues and does not have information on the characteristics of amortization of the bonds, making it impossible to estimate external debt of those countries. Importantly, Stone [1999] only covers issuance in London. During the $19^{\text {th }}$ and early $20^{\text {th }}$ centuries Paris, Frankfurt Berlin, and New York were also the capitals of the international financial markets. Many countries in the periphery (for example in Continental Europe) floated most of their bonds and shares in Paris, Frankfurt, and Berlin. Thus, just capturing issuance in London provides a biased indicator of access to international capital markets for many countries. 
First, although many have argued that cyclical monetary policy in the financial center since the 1970 s is at the core of volatile and excessive booms and busts in capital flows to the emerging periphery, capital flow bonanzas and busts are far more pronounced during the first episode of financial globalization when monetary policy in the financial center is constrained by the adherence to the Gold Standard.

Second, the differences in the magnitude of the booms and busts of capital flows to the emerging periphery in the first and second episodes of financial globalization are driven by capital flow cycles around crises in the financial center. During the first episode of financial globalization, capital flows during the bonanzas that precede panics in the financial center are about 60 percent larger than capital flows in bonanzas during tranquil times while capital flows during the busts that follow the crises in the financial center are approximately 50 percent smaller than capital flows in busts during tranquil times. In contrast, international capital flows to the periphery around crises in the financial center since the 1970s are characterized by smaller bonanzas and substantially more issuance during the bust. In fact, Systemic Capital Flow Bonanzas cannot be distinguished from Idiosyncratic Capital Flow Bonanzas in this period and capital flows during the busts that follow crises in the financial center are even larger that capital flows in busts during tranquil times.

Third, the changes in monetary regimes in the financial center (from adherence to the Gold Standard to autonomous monetary policy since the collapse of the Bretton Woods System) are at the core of the time-varying characteristics of international capital flow cycles to the emerging periphery around episodes of crisis in the financial center. Monetary cycles in the financial center during the second episode of financial globalization are far more pronounced around a panic in the financial center, with dramatic monetary contractions targeting the boom in credit preceding the crisis and a protracted expansionary monetary policy injecting liquidity to rein in the crisis. Naturally, these policies also substantially moderate capital flow bonanzas in the periphery and guarantee periphery countries better access to liquidity in international capital markets during the busts triggered by a panic in the financial center.

The rest of the paper is organized as follows. Section II describes the new database as well as its sources. Section III provides a short chronology of global capital flow cycles and Latin American countries' participation in international capital markets. Section IV examines the characteristics of booms and busts in international gross primary issuance for each Latin American country, it identifies varieties of capital flow cycles, and compares the borrowing cycles in both episodes of financial globalization. This Section also reports tests of the varying characteristics of capital flow cycles. Section $V$ examines the role of the domestic economy (pull factors) as well as world-wide shocks (push factors) on the characteristics of the capital flow cycles. Section VI concludes. 


\section{International Issuance: The Database}

The historical data on international capital flows of Latin American countries used in this paper is only a small part of the newly created database which includes all countries participating in international capital markets. The measure of capital flows in this database is what is known as international gross primary issuance. This measure of capital flows captures gross capital inflows and is defined as purchases of domestic assets by foreign residents. Until recently, the research on capital flows focused on the behavior of net capital flows (current account imbalances). ${ }^{6}$ At the core of this interest is the hypothesis that financial fragility and currency crises are triggered by sharp declines in savings (net of investment) and excessive external borrowing, which is captured by deficits in the current account. ${ }^{7}$ The Global Crisis in 2007-2009 changed that. This financial panic was not preceded by a surge in net capital inflows. Instead, there was a dramatic increase in gross financial flows while net capital flows remained mostly subdued. The new literature on capital flows thus identifies financial fragility with gross capital flows and external positions. ${ }^{8}$ The database I constructed will extend the analysis of boom-bust cycles of gross exposures for two hundred years.

This historical database is unique on its coverage.

First, it spans the whole first episode of financial globalization, from 1820 when London emerges as the financial capital of the world to 1931 when barriers to international capital mobility are erected around the world.

Second, this database not only includes governments' (central, provinces/states, and municipalities) international issuance but also international issuance of the private sector. Since the private sector has always participated intensively in international capital markets, omission of the private sector issuance severely underestimates capital flows.

Third, the database includes international issuance of bonds, loans, and shares, the major drivers of international capital flows.

\footnotetext{
${ }^{6}$ In some studies, net capital flows include not only current account imbalances but also changes in foreign exchange reserves.

7 See, for example, Calvo, Leiderman, and Reinhart [1993]; Fernandez-Arias [1996]; and Reinhart and Reinhart [2009].

${ }^{8}$ One of the earlier papers assessing the role of gross flows on financial fragility in the years predating the global crisis is Obstfeld [2012]. In this paper, Obstfeld describes how gross exposures in the presence of financial distortions can carry risks of financial instability regardless of whether the country has a current-account deficit or surplus. See also, Acharya and Schnabl [2010] and Borio and Disyatat [2011] for two exhaustive studies of the type of capital flows preceding the global crisis in 2008.
} 
Fourth, the database includes issuance data for all countries that participate in international capital markets, including countries like Paraguay, that only floats a few bonds during the first episode of financial globalization, to Australia, that issues thousands of bonds and shares in international capital markets during the same period. The inclusion of all countries that tap international capital markets at least once will allow us to examine not only those countries that are at the center of international capital flows but also study access to markets of low-income developing countries.

Fifth, the historical database includes all bonds and shares issued in London, Paris, Frankfurt, Berlin, Hamburg, and New York, the financial centers of that era. Coverage of flotations in all financial centers is essential since the importance of each financial center in the international capital market evolves over time. While London is the financial capital of the world in the earlier period, Paris, Berlin, Frankfurt, and Hamburg become major financial centers in the 1870s, with New York capturing international capital markets in the aftermath of WWI. Importantly, not all financial centers provide equal financing to all the periphery. For example, while the Commonwealth countries (Australia, Canada, India, New Zealand, and South Africa) basically only tap the London market, European countries (such as, Austria, Denmark, Hungary, Italy, Norway, the Ottoman Empire, Portugal, Russia, and Spain) issue bonds and shares massively in Paris as well as Frankfurt, Berlin, and Hamburg. ${ }^{9}$

Sixth, the database is granular. It contains information on each single issue. For bonds, the data includes the date of the issue, the name of the borrower, the purpose of the issue, the type of business of the borrower, the amount issued, the price of the issue (whether it is issued at par/premium/discount), the interest rate and the maturity of the bonds, the banks underwriting the issue, the financial centers where the bonds are issued, and the currency of issue. For shares, the data includes the date of the floating, the name of the company issuing the shares, the price of the shares, whether the shares are ordinary or preferred, the currency of issue, and the financial centers where the shares are issued.

\footnotetext{
${ }^{9}$ The historical database I constructed is not the first database on international capital flows during the first episode of financial globalization. Stone [1999] constructed a database of international capital flows using issuance of bonds and equity in London from 1865 to 1914 for twenty-one countries. Unfortunately, this database lacks information on the individual issues and does not have information on the characteristics of amortization of the bonds, making it impossible to estimate external debt of those countries. Importantly, Stone [1999] only covers issuance in London, capturing just a fraction of international capital flows. More recently, Reinhart, Reinhart, and Trebesch [2017] also examine capital flow cycles for the past 200 years. Unfortunately, their database is heterogenous in nature making it impossible to compare cycles across time. For the period 1815-1866, the authors construct a database that only includes international sovereign bond issuance for 38 countries in London. For the episode spanning 1867-1914, they use Stone [1999] international issuance in London for 25 countries. Finally, for the episode 1919-2016, they construct a database on capital flows using the Current Account and changes in Foreign Exchange Reserves for 60 countries, that is, this database combines gross capital flows from 1815 to 1914 with net capital flows since 1919.
} 
Lastly, the historical database (1820-1931) as well as the database for the modern era (starting in 1970) are identically constructed, including all bond/loans and shares issued in the financial centers. This is a pre-requisite to compare the boom-bust cycles in the two episodes of financial globalization.

I collected the historical data for this project from many sources. They include financial newspapers and magazines of the $19^{\text {th }}$ and early $20^{\text {th }}$ centuries (such as The Statist, l'Economiste Européen, and Dt. Oekonomist), annual reports of the Stock Exchanges in London and Paris, the Annual Listings of Bonds and Stocks in the Berlin, Frankfurt, and Hamburg Stock Exchanges, the archives of the London Stock Exchange, the Paris Bourse, and the New York Stock Exchange, as well as the archives of merchant banks (such as the House of Rothschild and Baring Brothers in London) and deposit banks (such as the Credit Lyonnais in Paris). The historical database also includes information on issuance collected from Investors Monthly Manual (1865-1914) as well as thousands of prospectuses of bonds and shares issued in London, Paris, and New York. I have also used information on issuance from the Fenn's Compendium, the Annual Report of the Confederation of Foreign Bondholders, the Annual Report of the Foreign Bondholders Protective Council, as well as Moody's, Kimber, and Fitch manuals on government borrowing in both domestic and international capital markets. I have also obtained data from publications from government agencies in the United States, such as the Department of Commerce and the Federal Reserve. Part of the database has also been collected from important studies on sovereign debt by scholars in Africa, Asia, Europe, Latin America, and Oceania.

To introduce the historical data, I present two prospectuses in Figure $I^{10}$ The first one is a 1,034,700 British-pound bond issued by the Province of Buenos Aires (Argentina) in 1870 . This is a $6 \%$ loan issued at a discount ( 88 percent of face value) redeemable in 33 years, with interest paid twice a year in London. This bond, like most sovereign bonds in the early phase of financial integration, is callable, allowing governments to refinance their debt in low-interest rate years. The second one is a $5 \%$ mortgage bond issued by the Railway Company Victoria to Minas in Brazil in 1911 for 25 million French francs redeemable in 89 years and issued in Paris.

Although not shown in Figure I, these bonds are, like most of the bonds issued in the $19^{\text {th }}$ and early $20^{\text {th }}$ centuries, sinking fund bonds equivalent to mortgage loans today. For example, the Buenos Aires $6 \%$ bond has an accumulative sinking fund of $1 \%$. The total annual service of this loan is $7 \%$ ( $1 \%$ for the sinking fund and $6 \%$ for the coupon rate) of the total amount issued. For the 1,034,700 British pound bond, the annual service is equal to 72,429 British pounds. As with mortgages, the service mostly pays

\footnotetext{
${ }^{10}$ These photos only include the top part of the prospectuses.
} 
the coupons in the first years of the life of the bond, with the part dedicated to the amortization increasing over time. In the case of the Buenos Aires $6 \%$ bond, the service is partly used to amortize the bond by annual drawings of the bond at par. More infrequently, bonds are bullet bonds, with the face value of the principal paid at maturity. The information on repayment characteristics of the bonds is used to estimate net primary issuance (gross primary issuance minus amortization) and to construct series of both public and private debt.

The information in the prospectuses at the time of issuance, annual reports of the Stock Exchanges, and listings in financial newspapers only provides the originally planned repayment characteristics of bonds. But most bonds are callable, allowing the borrower to repay the bonds earlier. During the first episode of financial globalization, there are waves of refinancing in low-interest rate years, with old high-coupon bonds converted into newly issued low-coupon bonds. For example, Figure I also shows the prospectus announcing the 1889 conversion of the Argentine 6\% Bonds of 1871 and 1882 and the Buenos Aires 6\% Bonds of 1870 and 1873 into a f5,263,560 4.5\% Argentine Government Sterling Bond. To estimate net issuance and debt series, it is necessary to identify these conversions. The original repayments of the bonds also change when countries default. To estimate net issuance and construct series of external debt it is necessary to study in detail the characteristics of the restructurings. The data on conversions and restructurings is obtained from the Annual Reports of the British Confederation of Foreign Bond Holders, the United States Foreign Bondholders Protective Council, and L'Association Nationale des Porteurs Français de Valeurs Mobiliers. The information from these institutions is complemented with data from Moody's, Kimber, and Fitch Government Manuals, as well as from studies of sovereign defaults by scholars around the world, such as Jorgensen and Sachs [1989] and Kaminsky and Vega-García [2016].

The historical database is complemented with a similar database for the second episode of financial globalization starting in the 1970s. As with the database for the first episode of financial globalization, the database for this period includes the bonds and shares floated in international capital markets. It also includes international syndicated loans. ${ }^{11}$ I collect data from the World Bank Archives as well as from Dealogic, Datastream, and Bloomberg terminals. I also collect data on the restructurings/exchanges following the defaults from Bloomberg terminals, the database of the

\footnotetext{
11 I follow the BIS in the identification of international syndicated loans (See, Gadanecz [2004]) and identify international loans as those loans in which the nationality of at least one of the senior syndicate banks differs from that of the borrower.
} 
International Finance Institute, International Monetary Fund publications, and a variety of studies examining restructurings of debt, such as Sturzenegger and Zettelmeyer [2006].

The worldwide historical data on bonds and shares floated in international markets contains roughly 155,000 entries ${ }^{12}$ disaggregated as follows: 95,000 prospectuses and entries in listings from the Annual Reports of the Stock Exchanges in London, Paris, Berlin, Frankfurt, Hamburg, and New York, 44,000 entries from the Investor Monthly Manual, 12,000 entries from Moody's, Kimber, and Fitch manuals, 2,000 entries from the archives of Rothschild (London), Baring Brothers (London), and Credit Lyonnais (Paris), and about 2,000 entries from individual studies on sovereign issuance of countries in Asia, Europe, Latin America and Oceania. None of these sources are complete and many issues of bonds and shares are included in various publications. Thus, the database is compiled country by country to eliminate repeated entries. Repeated entries not only appear in various sources for one financial center, but also in publications across various financial centers. This mostly happens with government bonds since many of them are floated in various financial centers simultaneously. For example, the $£ 25,000,000$ Japanese $4 \%$ Bond of 1905 is issued simultaneously in London, Paris, New York, and Germany and the $£ 8,000,000$ Royal Hungarian 6\% Rentes of 1877 is issued simultaneously in London, Paris, Vienna, Berlin and Frankfurt. The construction of the database required an immense amount of time spent in the archives and in the processing of the data.

The equivalent database for the second episode of financial globalization includes about 480,000 entries, including bonds, shares, and syndicated loans.

\section{Global Capital Flows and Latin America's International Borrowing since 1820: A Chronology ${ }^{13}$}

The first international capital flow bonanza starts in the early 1820s. At the core of this cycle is the increase in liquidity fueled by the sharp decline in military spending following the end of the Napoleonic wars, with London as the new financial capital of the world. This capital flow bonanza engulfs Europe, with Austria, Belgium, Denmark, Greece, Portugal, Russia, Spain, and a variety of Italian States (Naples, Piedmont, Tuscany, and the Papal States) issuing their first international bonds. This bonanza also spreads to Latin America. Almost all Latin American countries gain independence from Spain and Portugal in the early 1800s. The new independent countries immediately eliminate the restrictions to trade imposed on the colonies by Spain and Portugal. International trade starts and participation in

\footnotetext{
${ }^{12}$ The counting also includes domestic issues from some of the sources.

${ }^{13}$ This section draws in part from Bordo and Murshid [1999] and Marichal [1989] detailed chronologies of capital flows and crises during the first episode of financial globalization and from de la Torre, Gozzi, and Schmukler [2008] analysis of the development of international capital markets during the second episode of financial globalization.
} 
international capital markets soon follows. The first Latin American country to float bonds in London is Gran Colombia. The first issue is in 1820 for 547,784 British pounds. By the end of 1825, Latin American's total international issuance has reached 20 million British pounds. The boom of the 1820 s is mostly due to loans to the governments of the newly independent countries. This episode also witnesses the creation of new companies in the mining sector in various Latin American countries. In total, twenty-eight companies are formed with a proposed capitalization of 24 million British pounds. Still, the shares issued in the 1820 s amount to only 3.5 million British pounds.

The boom ends in the summer of 1825 when the Bank of England raises the discount rate to stop the drain of reserves fueled by the import boom and the outflow of capital. The tightening of liquidity is followed by a stock market crash in October, a banking panic in December, and numerous bankruptcies. The financial debacle in London rapidly spreads to continental Europe, with bankruptcies of major banks in Germany, Italy, Amsterdam, Saint Petersburg, and Vienna. The crisis extends rapidly to Latin America as overseas loans are cut off. The crisis also triggers a major fiscal problem in Latin America. As world trade collapses, so do tariff revenues, the only source of income for the governments of the new countries. Argentina, Brazil, Chile, the Federation of Central America, Gran Colombia, Mexico, and Peru start defaulting in 1826.

International issuance restarts in the mid-1830s. This time around, the United States is the most important borrower. It is not the Federal Government but the States that are at the heart of the capital flow bonanza. By the end of the 1830s, nineteen U.S. states and two territories have issued bonds, with debt increasing by a factor of thirteen in just ten years. Most of the debt is issued abroad, primarily in London (see English [1996]). The bonanza also reaches European countries. Meanwhile, Latin American countries, still in default, are not able to tap international capital markets in this period. The boom ends in 1839 following the tightening of credit by the Bank of England, with the crash in international liquidity partly leading to the default of nine of the U.S. States starting in 1841.

As with the previous bonanza, the collapse in international liquidity is prolonged, with international capital flows starting to recover only in the 1850s. The capital flow bonanza now not only reaches Europe but also the Commonwealth countries (Australia, Canada, India, New Zealand, and South Africa). It also reaches Asia and the Middle East, with Algeria, China, Egypt, and the Ottoman Empire among the ones tapping international capital markets the most. Importantly, the recovery of the world economy starting in the late 1840s fuels a new boom in demand for primary products and raw materials, 
benefiting Latin American economies, in particular, Chile and Peru. ${ }^{14}$ The growing international trade accompanying the recovery in Europe fuels a new fiscal bonanza in all Latin American countries (as tariff revenues increase accordingly) and with it the possibility of the settlement of foreign debts. ${ }^{15}$ Peru is the first to issue a new bond in London in 1853. Still, the new loan boom to Latin America only flourishes in the 1860 s after the end of the panic of $1857 .{ }^{16}$

The capital flow bonanza to Latin America starting in the 1860 s is larger than the one of the early 1820 s, with capital flows financing not just governments and the extraction of mineral resources but also the creation of banks and the adoption of cutting-edge technologies such as telegraphs and railroads. It is during this period that numerous British banks are created following the laws in 1858 and 1862 allowing the formation of joint-stock banks with limited liability. This is also the period of the creation of deposit banks such as the Credit Lyonnais [1863) and investment banks (banques d'affaires) such as Banque de Paris et des Pays-Bas [1873), with both English and French banks founding new banks in continental Europe and Latin America. ${ }^{17}$ It is also during the 1860 s and 1870 s that the first joint-stock railway companies are formed. Railway construction is financed with international bonds, mortgage loans, and equity issuance. ${ }^{18}$ The capital inflows to Argentina, Brazil, Chile, Colombia, Mexico, Peru, and Uruguay during the 1860s and early 1870s reach 132 million British pounds. The world international capital flow bonanza slows down with the British crisis in $1866 .{ }^{19}$ By the early 1870 s Latin American countries are heavily participating in international capital markets again. In this episode, Peru becomes the most indebted country in Latin America, with its foreign debt increasing from 7 million British pounds in 1856

\footnotetext{
${ }^{14}$ The export of agricultural and mineral products surges dramatically: Guano from Peru, copper from Chile, wool from Argentina, coffee from Brazil, sugar and tobacco from Cuba, tobacco from Colombia, and silver from Mexico. See Marichal [1989].

${ }^{15}$ Chile is the first to renegotiate its debt in 1842, Peru follows in 1849. Most Latin American countries renegotiate their debts in the 1850s.

16 The crisis of 1857 begins in the U.S. A railroad stock boom fueled by British capital and the California gold discoveries in 1849 crashes in August 1857 with a banking panic. The crisis spreads to England in the Fall.

17 In Latin America, The London and Brazilian Bank is the first to be incorporated in May 1862 with a capital of $1,000,000$ British pounds; the London and River Plate Bank follows with a capital of 500,000 British pounds. In 1863, the London and South American Bank limited is founded and merged with the Mexican Bank in 1864 to form the London Bank of Mexico and South America Limited with a proposed capital of 1,000,000 British pounds. Many others, such as the London and Venezuelan Bank, the Mercantile Bank of the River Plate in Uruguay, and the Anglo Peruvian Bank are created in this period.

${ }^{18}$ Some of the earlier issues are those of the Brazilian Street Railway in 1869, the Sao Paulo Railway in 1870, City of Buenos Aires Street Railway in 1870, and Buenos Aires National Tramways Limited also in 1870.

${ }^{19}$ The crisis of 1866 is preceded by a large credit expansion both in England and France that triggers a boom in prices of intermediate goods, construction, and cotton-related industries. The boom ends with the panic of 1866 when Overend \& Gurney, a major discount firm in London, collapses. France's first investment bank, Crédit Mobilier, also fails.
} 
to 36 million British pounds in 1876. The collateral provided by the exports of guano, monopolized by the Peruvian government, allows Peru's government to access international capital markets in such a grand manner.

The capital flow boom ends with the crisis of 1873. The end of the Franco-Prussian War in 1870 plays a critical part in the unfolding of the crisis of 1873. Following the defeat of Napoleon III, the new French government pays a huge indemnity of 5,000 million francs (200 million British pounds) to Germany. These indemnity transfers lead to a massive flow of capital into the economies of central Europe, fueling speculation in various financial markets. A spectacular stock market crash in Vienna in May of 1873 ends with the stock market boom in Austria and spreads rapidly to Germany. Between 1873 and 1878, half of the Austrian banks close, and 400 of the 800 Austrian join-stock companies go bankrupt. Stock markets in Amsterdam and Zurich also crash. The crisis crosses the Atlantic in September. The New York Stock market collapses and is followed with a U.S. banking panic. As during the crisis of 1825 , there is a collapse in world trade and in the prices of commodities, and loans are called off. Tax revenues in Latin America sharply drop and trigger a new wave of defaults across the region. The steep decline in commodity and stock prices as well as banking and industrial bankruptcies in most countries start the first worldwide recession in 1873. The crisis is also felt in the Middle East. By 1876, the Ottoman Empire, Egypt, Greece, and Tunisia have defaulted. In total, by the year 1876, fifteen non-European nations have suspended payments on almost 30 million British pounds. In Latin America, Bolivia, Colombia, Costa Rica, Guatemala, Honduras, Peru, and Uruguay default on their foreign debt.

While the depression of the 1873 wreaks havoc around the world, by the early 1880s the process of recovery has begun. The upswing in world economic activity fuels foreign trade and new capital flows to countries in the periphery. Again, as in the 1860 s and 1870s, capital flows finance not just governments but also private activities in new industries, such as firms in the food sector, railways, tramways, construction of ports, gas works, and of course, the production of raw materials, mining, and land companies. Latin America also benefits from this new capital flow bonanza. From 1874 until the late 1880s, international gross primary issuance by the seven largest Latin American countries reaches 280 million British pounds, with Argentina and Uruguay being the most important recipients. The boom of the 1880 s ends in 1890 with the crisis set off by the near-failure of Baring Brothers, the underwriter of Argentine Government loans. The Bank of England prevents a panic via a recapitalization of Baring Brothers with the help of other major London financial institutions and loans from the Banque de France and Russia. Still, the crisis spreads back to Latin America with the cessation of British lending to Argentina and Uruguay. Between 1890 and 1894, Argentina, Ecuador, Guatemala, Nicaragua, Paraguay, Uruguay, 
and Venezuela default. A sharp worldwide decline in the flow of British capital follows this crisis, partly triggering major banking crises in the United States and Australia in 1893.

The next international capital flow cycle starts in the late-1890s and ends with the start of WWI. ${ }^{20}$ While Britain continues to be the main creditor, French, German and American investors set up new companies in banking as well as in railways, canals, tramways, mines, ports, sugar refineries, flour mills, gas works, water works, and even some early electric and telephone companies. This episode is considered until now the heyday of financial globalization. From 1890 until the start of WWI capital flows to Argentina, Brazil, Chile, Colombia, Mexico, Peru, and Uruguay reach almost 1 billion British pounds. A large part of the international issuance of Latin America finances the construction of railways and tramways, ports, gas works, and water drainages, as well as firms in the food, textile, and retail sectors. Other areas financed by international capital flows are land development, coffee and sugar plantations, production of nitrates, and general mining operations. The outbreak of World War I contributes to the end of this boom in international capital flows. In July, as war becomes imminent, a liquidity crunch spreads around the world as investors start to liquidate foreign assets, fueling panics in all asset markets. While the panic is promptly stopped by the central banks in the United Kingdom, the United States, and continental Europe, the outbreak of the war in Europe causes an abrupt suspension of capital flows. This time around, the governments of most nations of the region continue to service their debt using export surpluses. Only Brazil, Ecuador, Mexico, and Uruguay default.

Capital flows resume with the end of the war in Europe. Increases in productivity due to major inventions, including electricity, automobiles, communications, and petrochemicals lead to a boom in economic activity that spills over to all the world. Most Latin American nations benefit from the continuing rise in international prices of raw materials and primary products. New York becomes the leading financial center. Meanwhile, lending from London and Paris retrenches following the imposition of capital controls in Great Britain and France ${ }^{21}$ and capital markets in Germany collapse. Again, Latin

\footnotetext{
20 This boom is interrupted in 1907 with a crisis originating in the United States following the San Francisco earthquake in April 1906. The destruction caused by the earthquake puts pressure on financial resources in the United States and puts strain on the Bank of England's reserves when British insurance companies start to pay out the U.S. claims. To stop the loss of reserves, the Bank of England hikes the discount rate from 3.5 to 6 percent causing a liquidity crunch in the United States. The U.S. stock mark crashes in early 1907 and economic activity begins to decline. In October, depositor runs on trust companies spread to the commercial banks. Banks suspend cash payments and the economy enters a sharp recession [See Bordo and Murshid, 1999].

${ }^{21}$ Foreign lending is formally restricted in Great Britain starting in December 1914. While formal restrictions are removed in various stages and are eliminated in November 1919, foreign lending continues to be restricted by the Bank of England, with control undertaken through moral suasion. As discussed in Cottrell [2005] all projected foreign flotations had to be discussed with the Bank of England's Governor.
} 
America starts tapping international capital markets, with the accumulated total gross issuance by Argentina, Brazil, Chile, Colombia, Mexico, Peru, and Uruguay during this cycle totaling about 600 million British pounds. Importantly, most borrowing is public, both in Latin America and the rest of the world. In 1927-1928 the Federal Reserve, concerned over stock market speculation, tightens monetary policy; a recession begins in July 1929. Prices of commodities collapse, stock markets around the globe crash, and capital flows sharply decline, precipitating currency and banking crises in Latin America, Europe, and Australia. Great Britain abandons the Gold Standard in September 1931 and the United States follows in January 1934. Bolivia, Brazil, Chile, Colombia, Costa Rica, Cuba, the Dominican Republic, Guatemala, Nicaragua, Panama, Paraguay, Peru, and Uruguay default in the early 1930s. Barriers to capital flows are erected around the globe ending this first episode of financial globalization.

During the next forty years, international capital flows languish amid restrictions to capital mobility in both developed and developing countries only to recover following the collapse of the Bretton Woods System. Ironically, the revival of international capital markets can be traced to new financial restrictions in Great Britain and the United States in the late 1950s and 1960s. In 1957, the British government introduces new financial restrictions in the vain attempt to stop the speculation against the British pound. In the end, the devaluation is not averted. But the restrictions make London-based banks create a new market to avoid losing their share of financial transactions: Banks' dollar deposits start to be used to provide dollar loans in an unregulated market which comes to be known as the Eurodollar market. In 1964, it is the U.S.'s turn. This time, the currency under attack is the U.S. dollar. To stop the speculation, the U.S. government introduces capital account controls in $1964 .{ }^{22}$ U.S. based-banks, like their British counterparts in the 1950s, turn to the Eurodollar market to avoid the restrictions that could imperil their operations, with liquidity in this market sharply increasing.

But perhaps the straw that broke the camel's back is the collapse of the Bretton Woods system in 1973. With no need to defend the peg, countries can now choose their own monetary policy without the need to restrict capital mobility and thus a new era of financial liberalization begins. As early as July 1973, United States eliminates capital account restrictions. Germany and Great Britain follow, partially eliminating capital controls in 1973 while Japan joins in 1979. In the late 1970s, Latin American countries deregulate the domestic banking sector and eliminate restrictions on international capital flows.

\footnotetext{
22 In September 1964, the United States Congress enacts the Interest Equalization Tax (IET), an excise tax on purchases of new or outstanding foreign stocks and bonds by U.S. residents, which lowers the rate of return to U.S. purchasers of foreign assets by an equivalent of 1 percentage point.
} 
The first international market to develop in the 1970s is the syndicated loan market, particularly with lending to emerging markets. The dramatic surge in international loans is triggered by the oil shock in 1973-74, with the high savings of OPEC countries being channeled through the Eurodollar market to emerging economies particularly during the 1979-81 period. The boom in syndicated lending to emerging markets peaks at 57 billion dollars in 1981. However, in 1982 international issuance collapses. At the heart of this collapse are the monetary contraction, the recession, and the banking distress in the United States. Mexico's default in August of 1982 adds to the fragility of the commercial banking sector in the United States. With U.S. banks recalling their loans from all emerging markets, other defaults follow. Most of the Latin American countries suspend interest and principal payments. They are soon followed by countries in Asia, Eastern Europe, and Africa. The rest of the 1980s witness a pronounced downturn in lending to emerging economies: Gross issuance of syndicated loans remains at half of the issuance reached in the early 1980s. With all large U.S. commercial banks heavily exposed to the emerging countries now in default, the policy in the U.S. is to maintain current interest servicing by debtor countries to the U.S. banks. This is done mostly by creating a new plan of "involuntary" loans from the exposed U.S. commercial banks while at the same time promoting continuous negotiations and extending the maturity of the loans. This arrangement allows the banks to keep all their loans on the books at face value, even though they are heavily discounted in the secondary market. ${ }^{23}$ Monetary policy in the U.S. is also heavily relaxed to ameliorate the overall distress in the financial sector and reverse the downturn in the economy.

The Brady plan and its initiative to restructure defaulted loans starting in 1989 ends with the isolation of developing markets from international capital markets. ${ }^{24}$ This time around, both the government and the private sector of developing countries start issuing bonds in international capital markets. Latin America benefits especially from the new international bond market. In fact, issuance in the bond market surpasses that of the syndicated loan market, with Latin American countries' bond issuance increasing from 2 billion dollars in 1990 to 84 billion dollars in 1997.

The Brady plan also provides a new impetus to the syndicated loan market. Helped by the easy monetary conditions in industrial countries in the early 1990s, syndicated loans reach a new peak at 190 billion dollars in 1997, almost four times higher than the level reached in the early 1980s. This time

\footnotetext{
${ }^{23}$ See Sachs [1986] and Sachs and Huizinga [1987].

${ }^{24}$ The key innovation of the Brady Plan is to allow the commercial banks to exchange their claims on developing countries into tradeable instruments, allowing them to eliminate the debt from their balance sheets and creating a market for sovereign emerging market bonds.
} 
around, the largest beneficiaries in emerging markets are the East Asian countries, with gross issuance reaching almost 100 billion dollars in 1997. The nationality of lenders also changes. While in the early 1980 s most of the syndicates are composed of U.S. banks, in the 1990s Japanese and European banks play a leading role in lending to emerging markets, especially to East Asian countries. The boom in the 1990s in the syndicated loan market is not confined to emerging markets. By 2004, international syndicated lending has increased to 2.5 trillion dollars, with developed countries capturing the lion's share of the international syndicated loan market, with gross issuance reaching 1.8 trillion dollars in 2004. Moreover, the expansion of the bond and syndicated loan markets in the 1990s is now accompanied by the development of an international equity market. However, the 1990s much like the 1980s are plagued by crises. In the aftermath of these crises, net capital flows to Latin America decline with total issuance falling to about 60 percent of its peak in 1997.

The last wave of international lending starts in the early 2000s. While capital flows to all emerging markets start to grow again, the lion's share continues to flow to advanced economies. Total international issuance peaks in 2007. Amid this boom, monetary policy is severely tightened, with the Federal Funds interest rate increasing from 1 percent in 2003 to 5 percent in 2007. As with the banking crisis in the United States in the 1980s, the U.S. monetary policy is dramatically reversed following the 2008 panic in the United States. The Federal Reserve sharply reduces the Federal Funds interest rate to zero, and the money base surges, reaching about 25 percent of GDP. Latin American international issuance is only transitorily affected by the Subprime crisis in the United States. Its total international issuance increases until 2014 and peaks at 217 billion dollars, only to decline by 37 percent in 2015 .

\section{International Borrowing Cycles: Then and Now}

This Section first shows the newly constructed series of international gross primary issuance for the Latin American countries for both episodes of financial globalization. Second, it discusses the identification of capital flow cycles. Third, it examines and tests the evolving characteristics of booms and busts in capital flows as well as each country's annual access to international capital markets.

\section{IV.A. Capital Flows to Latin America}

Figure II first shows the newly collected data covering the period from 1820 to 1931 and then reports the data for the 1970-2015 episode. ${ }^{25}$ This figure shows the international gross primary issuance of Latin America as captured by the issuance of Argentina, Brazil, Chile, Colombia, Mexico, Peru, and

\footnotetext{
25 Issuance includes both issuance of bonds and shares for the first episode of financial globalization and includes issuance of bonds, syndicated loans, and shares for the second episode of financial globalization.
} 
Uruguay. These seven countries are the most active participants in international capital markets in the region during the first and second episodes of financial globalization. The data on gross primary issuance that I construct captures access to international capital markets, that is, it only includes issuance for cash. As estimated, gross primary issuance does not include the value of the bonds issued in exchange for previously issued bonds via a conversion or an exchange of defaulted bonds for new bonds when the default ends. It also does not include bonds issued to pay accumulated coupon arrears when the debt is restructured to end a default. Finally, all bond issuance is measured at face value.

For the first episode of financial globalization, the top panel shows total international gross primary issuance in British pounds and the middle panel decomposes total issuance into public and private issuance. The bottom panel shows the international gross primary issuance/exports ratio to have a measure of participation in international capital markets relative to the size of the economy. As shown in Figure II, there are clear boom-bust episodes throughout the $19^{\text {th }}$ and early $20^{\text {th }}$ centuries peaking around 1824, 1865, 1873, 1888, 1910, and 1928.

An important international finance literature on Latin American participation in international capital markets during the first episode of financial globalization has been concerned with only sovereign borrowing. Still, as shown in Figure II's middle panel, private international issuance has been very important during this episode, with the private share oscillating around 46 percent, making it imperative to assess the contribution of private issuance to these cycles. The share of private issuance changes over time. In the 1820 s, private issuance is just 10 percent of total issuance. In the 1860 s and early 1870 s, private issuance increases to about 30 percent of total issuance while in the 1880s private issuance reaches 55 percent of total issuance. Private issuance at the turn of the century until the WWI is approximately 65 percent of total issuance and then declines to 20 percent during the last capital flow bonanza before the crisis of 1931. During this episode, the correlation between public and private international issuance is almost 0.50 , with private borrowing reinforcing sovereign borrowing cycles.

However, Information on total issuance is insufficient to compare the extent of financial integration during this episode. We need to scale total issuance with an indicator of the size of the economy. The most common indicator used to capture the extent of integration across countries is the ratio of total issuance (or gross capital inflows) to GDP. Official estimates of GDP for the $19^{\text {th }}$ century and even the early $20^{\text {th }}$ century are not available. Instead, I use exports as the scale variable. ${ }^{26}$ Figure II's

\footnotetext{
${ }^{26}$ Exports are quite volatile. For the issuance/export ratio to capture the volatility of capital flows only, I use trend exports as the scale variable. Trend exports are estimated by applying the Hodrick-Prescott filter to the series of exports in British pounds for the first episode of financial globalization and in US dollars for the second episode of
} 
bottom panel shows the issuance/exports ratio. Average issuance/exports is 15 percent during the first episode of financial globalization (starting in 1820 and ending in 1931) with a peak at 121 percent in 1824.

Figure II also shows similar graphs for the second episode of financial globalization, starting in the 1970s. The top panel shows Latin America's international gross issuance in US dollars. This panel clearly shows three cycles with peaks in 1981, 1997, and 2014. The second panel shows the decomposition of issuance into public and private. As in the first episode of financial globalization, the first cycle is mostly about government borrowing. In contrast, the bonanzas of the 1990s and the 2000s are on average 60 percent private issuance. The bottom panel shows total issuance as a share of exports. Interestingly, the capital flow bonanza of the 2000 s is milder than those of the earlier periods when issuance is scaled by exports.

I now examine in more detail the capital flow cycles for the seven countries in the sample. Figure III shows gross international primary issuance for each country as a share of exports. The blue bars in this figure show international issuance (as a share of exports). Data on issuance is quite volatile, in large part because government bonds are issued in large tranches. To have a better visualization of booms and busts, the red line in Figure III also shows international primary issuance as a three-year moving average (as a share of exports). As shown in Figure III, during the first episode of financial globalization, booms and busts in international issuance across the seven countries are highly correlated, with mostly all countries participating in each cycle. ${ }^{27}$ There are two exceptions: Colombia and Mexico. Following the boom of the 1820s, all Latin American countries default. These defaults last around 30 years. Following the debt restructurings, mostly in the 1850s, Argentina, Brazil, Chile, and Peru start tapping international capital markets again in the 1860s. In contrast, Colombia and Mexico, amid serial defaults, ${ }^{28}$ are out of the international capital markets until the beginning of the $20^{\text {th }}$ century and the 1880 s, respectively. ${ }^{29}$ The figures for the second episode of financial globalization also show that cycles are highly correlated across the countries. With the exception of Argentina (following the default of 2001), all countries participate in the capital flow bonanzas of the 1970s, 1990s, and 2000s.

\footnotetext{
financial globalization.

${ }^{27}$ Uruguay starts tapping international capital markets for the first time in 1864.

${ }^{28}$ During the period 1826 to 1905 Colombia defaults 5 times, with Colombia being in default in total for 70 years. Mexico defaults twice, in 1827 and in 1854. The first default last 25 years and the second lasts 33 years.

${ }^{29}$ Even in default, Mexico taps international capital markets in the 1860s during the French intervention from 1861 to 1867. During the intervention, the French government imposes Maximiliam I as emperor. During this period, the government of Maximiliam I issues bonds in Paris. After the French intervention is defeated, Benito Juárez is reelected president and the loans contracted by the government of Maximiliam I are repudiated.
} 


\section{IV.B. Identification of Capital Flow Cycles}

I now examine more systematically the boom-bust capital flow cycles by looking at their duration and amplitude. To identify the boom-bust cycles in gross international issuance, I apply an algorithm used to identify real business and stock market cycles. ${ }^{30}$ This algorithm isolates local maxima in a time series subject to a minimum constraint on the length of upturns and downturns. To identify bona fide bonanzas and not just blips in issuance, I also impose a constraint of a minimum level of issuance (as a share of exports) at the peak of the cycle. In particular, I impose the restriction that the cycle cannot have duration of less than 5 years. That is, $y_{t}$ (international issuance as a share of exports) is a maximum if:

$$
y_{t-2}<y_{t-1}<y_{t}>y_{t+1}>y_{t+2}
$$

and $y_{t}$ is at least 0.15 . The trough is identified as the minimum value between two local peaks.

I apply this filter to the (3-year moving average) total issuance/exports ratio for each of the seven countries in the sample. The algorithm identifies 34 cycles for the first episode of financial globalization and 22 for the second episode of financial globalization. Table I shows the characteristics of these cycles. The average duration of the capital flow bonanzas is 8 years in the two episodes. For the first episode of financial globalization, the minimum boom duration is 2 years and the maximum boom duration is 18 years. For the second episode of financial globalization, the minimum boom duration is 3 years and the maximum boom duration is 13 years. Interestingly, the length of the bust during the first episode of financial globalization is more varied. Although the minimum duration of the bust is 2 years, capital flow busts can last much longer. For example, Colombia, after the capital flow bonanza of the 1820s and amid serial defaults, cannot tap international capital markets for 79 years. However, long-lasting bust spells may be due to global patterns. For example, following the Great Depression in 1931, barriers to capital flows are erected around the world with international capital markets disappearing for about 40 years. Latin American countries only start tapping international capital markets in the 1970s. The duration of the busts during the second episode of financial globalization is less volatile than that of the earlier episode, with the most protracted bust lasting 18 years (for Argentina following the default of 2001) and the shortest lasting 2 years. ${ }^{31}$

\footnotetext{
${ }^{30}$ See, for example, Bry and Boschan [1971], Harding and Pagan [2002], and Kaminsky and Schmukler [2008].

${ }^{31}$ Note that the last cycle for some of the countries is incomplete, so I cannot compute the complete duration of some of the cycles of the 2000 s.
} 
To examine the magnitude of the capital flow bonanzas and capital flow busts I need to estimate the accumulated net issuance during a boom and during a bust. ${ }^{32}$ I estimate the amplitude of the bonanza (bust) for each cycle $i$ as follows:

$$
\text { amplitude }_{i}=\sum_{t_{i}=1}^{T_{i}}\left(\frac{\text { net } \text { issuance }_{t_{i}}}{X_{T_{i}}}\right)
$$

Where 1 is the year when the capital flow bonanza (bust) starts. For bonanzas, $T$ is the year of the peak of the capital flow cycle and the numerator is total accumulated net issuance over the boom normalized by the level of exports in the year of the peak of the cycle. For busts, $T$ is the year of the trough of the capital flow cycle and the numerator is total accumulated net issuance over the bust normalized by the level of exports in the year of the trough of the cycle.

\section{IV.C. Varieties of Capital Flow Cycles and Access to International Capital Markets}

This section studies and tests whether the characteristics of bonanzas and busts change from the first episode to the second episode of financial globalization. It also examines whether the characteristics of capital flow cycles in the emerging periphery change depending on whether there is a crisis in the financial center or not. Finally, it also studies the access to international capital markets at annual frequencies.

As I discussed in previous sections, the first episode of financial globalization was mired in panics with the financial center at its epicenter. As examined in a variety of chronologies (see, for example, Bordo and Murshid [1999]; and Kaminsky and Vega-García [2016]), the most virulent crises in the $19^{\text {th }}$ and early $20^{\text {th }}$ centuries are the 1825 crisis in London, the 1873 crisis in continental Europe, the Baring crisis in London in 1890, and the London and New York 1929 crisis that heralds the Great Depression. The second episode of financial globalization is witness to two worldwide financial crises with the financial center at its epicenter. The first crisis erupts in the United States in the early 1980s. The crisis bursts amid the tightening in monetary policy in the United States and is preceded by a large boom in international lending to emerging markets by large U.S. commercial banks. ${ }^{33}$ This crisis spreads around the globe, triggering

\footnotetext{
32 Net primary issuance is estimated by subtracting cash amortizations from gross primary issuance (also for cash). In contrast, the debt series include the remaining value of all the bonds issued for cash as well as that of the new bonds issued in conversions or bonds issued in the aftermath of defaults to exchange the original bonds or to pay the accumulated arrears in coupons while eliminating the bonds converted. That is, debt increases with new borrowing for cash and the issuance of bonds to pay coupon arrears as well as with the issuance of conversion bonds and declines with the amortization of bonds with cash payments or with new bonds.

${ }^{33}$ The boom in international lending to emerging economies is not just a U.S. banking sector affair. Japanese banks and U.K. banks and some other European banks also participate in the lending boom, although the large U.S.
} 
defaults as well as currency and banking crises in Africa, Asia, Eastern Europe, Latin America, and the Middle East. The second crisis in the financial center erupts in 2007-2008, the so-called U.S. Subprime financial crisis. The crisis spreads to advanced economies around the world and almost triggers the collapse of the European Monetary Union. The crisis lingers for a decade with a global collapse in economic activity. As I stated before, I classify the capital flow cycles around a crisis in the financial center as Systemic Capital Flow Cycles ${ }^{34}$ and all the cycles unrelated to panics in the financial center as Idiosyncratic Capital Flow Cycles.

I first examine the characteristics of all cycles, then and now. Table II shows the amplitude of booms and busts in international borrowing, estimated as shown in (2). For the first episode of financial globalization, 1820-1931, the average capital flow bonanza is quite pronounced, with total accumulated net issuance across all countries averaging 194 percent of exports. Still, the amplitude of the cycles is quite varied with some bonanzas being extremely large and reaching almost seven hundred percent of exports and others much milder with accumulated total net issuance being just a fraction of exports during the cycle. Interestingly, some of the most extreme capital flow bonanzas occur in the 1820s, with Colombia and Mexico's bonanzas reaching seven and four hundred percent of their exports, respectively. Not surprisingly, Colombia's and Mexico's default spells following this boom are the longest, with endless restructurings until their debt burdens reach sustainable levels. ${ }^{35}$

For the first episode of financial globalization, accumulated net issuance during the busts substantially declines to about 25 percent of exports. Importantly, 30 percent of those busts are more extreme. During these extreme busts, countries are unable to tap international capital markets, with zero or even negative accumulated net issuance during the downturn in the cycle. The sharpest decline in issuance occurs in Peru following the 1873 world crisis. At that time, Peru's accumulated net issuance becomes negative, with the deleveraging reaching 58 percent of exports.

The estimates in Table III for the episode of 1970-2015 paint a different picture of capital flow booms and busts. The average capital flow bonanza for this episode is 113 percent of exports (only 60 percent of the average capital flow bonanzas in the earlier episode). In contrast, the average accumulated

commercial banks are the ones most heavily exposed to emerging markets in this first boom in international lending since the 1920s. See Sachs and Huizinga [1987].

${ }^{34}$ A capital flow cycle is identified as systemic if the capital flow bonanza starts before the onset of the crisis in the financial center and the peak of the cycle occurs at the most five years apart from the year of the crisis in the financial center.

${ }^{35}$ See Kaminsky and Vega-García [2016] for a detailed analysis of the sovereign debt crises in Latin America during the first episode of financial globalization. 
net issuance during the busts in the modern episode is larger than the one in the earlier period of financial globalization, with accumulated issuance during the bust averaging 38 percent of exports. Interestingly, extreme busts are less prevalent since the 1970s (only accounting for 5 percent of all the cycles) suggesting better access of Latin American countries to international capital markets in bad times.

Figure IV shows the amplitude of each capital flow bonanza and bust during the two episodes of financial globalization and tests whether they are systematically different then and now. As shown in this figure, the null hypothesis of equal bonanzas in the first and second episodes of financial globalization can be rejected with a p-value of 0.01 . On average, bonanzas in the first episode of financial globalization are 72 percent larger than those during the second episode of financial globalization (194 percent of exports in the first episode versus 113 percent of exports in the second episode). In contrast, the average accumulated net issuance during the busts in the second episode of financial globalization is about 50 percent larger than the one in the first episode of financial globalization ( 25 percent of exports during the first episode versus 38 percent of exports during the second episode). The null hypothesis of equality of busts across the two episodes can be rejected at a p-value of 0.09 .

Figure $\mathrm{V}$ studies jointly all capital flow cycles (during both the first and the second episode of financial globalization) and tests whether capital flow cycles around panics in the financial center are different from those occurring during tranquil times. The top two panels in this figure identify the systemic bonanzas and busts with blue and the idiosyncratic bonanzas and busts with red. The bottom panel shows the average amplitude of the two varieties of capital flow bonanzas and busts and reports the p-values of the null hypothesis of equality of booms (busts) of the two varieties of cycles. The data indicates that bonanzas predating global crises are more dramatic than those during tranquil times. The average systemic bonanza equals 186 percent of exports while the average idiosyncratic bonanza equals 130 percent of exports. The null hypothesis of equality is rejected at a p-value of 0.05 . Interestingly, contrary to the current discussions on sudden stops and volatility of the capital flow cycles following the crisis in 2008 , busts following crises in the financial center are not different from those observed during tranquil times. The $p$-value is equal to 0.25 .

Figure VI examines whether the characteristics of systemic and idiosyncratic cycles change over time. The first episode of financial globalization is witness to four major crises in the financial center: $1825,1873,1890$, and 1929 . These crises are preceded by more extreme capital flow bonanzas. The average bonanza in Latin America for booms preceding panics in the financial centers reaches 226 percent of exports while the average bonanza unrelated to these global panics only reaches 142 percent of exports. As shown in Figure VI, the null hypothesis of equality of systemic and idiosyncratic bonanzas 
during the first episode of financial globalization can be rejected with a p-value of 0.06 . The estimates shown for the period of 1970-2015 paint a completely different picture of capital flow bonanzas for the second episode of financial globalization. The average capital flow bonanza in Latin America preceding the financial crises in the United States in the early 1980s and in 2007-2008 only reaches 111 percent of exports. This is very close to the bonanzas in tranquil times, which average 115 percent of exports. In fact, the null hypothesis of equality of systemic and idiosyncratic bonanzas during the second episode of financial globalization cannot be rejected at any conventional significance level ( $p$-value of 0.44 ).

Figure VI also examines the characteristics of issuance during bad times (the busts). During the first episode of financial globalization, countries have less access to international capital markets in the aftermath of a panic in the financial center when compared to idiosyncratic busts. Following panics in the financial center, Latin American countries cannot access international capital markets, with average issuance during the bust only reaching 19 percent of exports. In contrast, average issuance during idiosyncratic busts reaches 35 percent of exports. The null hypothesis of equality of systemic and idiosyncratic busts during the first episode of financial globalization can be rejected at a 0.10 confidence level. Interestingly, during the second episode of financial globalization, Latin American countries' issuance in the aftermath of crisis in the financial center averages 59 percent of exports, almost four times the issuance during idiosyncratic cycles, which only averages 15 percent of exports. Again, the hypothesis of equality of issuance during systemic and idiosyncratic busts can be rejected at all conventional significance levels ( $p$-value of 0.00 ).

There may be many drivers of this different participation of Latin American countries in international capital markets. However, many have argued that monetary policy cycles in the financial center since the restart of financial globalization in the 1970s have been at the core of dramatic booms and busts in capital flows to emerging markets. In contrast, the evidence presented in Figures IV and VI for the two episodes of financial globalization indicates that capital flow cycles have become less pronounced since the restart of financial globalization in the 1970s. This evidence suggests that we need to re-evaluate the role of monetary policy in the financial center.

The previous results focus exclusively on similarities and differences in access to capital markets over phases of booms and busts. They leave unanswered questions about continuous access to international capital markets and overall volatility in access to international capital markets in the first and second episodes of financial globalization. To test whether international capital markets behave differently in these two episodes, I estimate separately the frequency distributions of annual capital flows in the 1820-1931 and 1970-2015 episodes for each country and compare these two distributions using 
the Kolmogorov-Smirnov test of equality of distributions. ${ }^{36}$ Figure VII shows these results. This figure first reports the histograms of annual international issuance/exports ratio for the first and second episode of financial globalization for each country. Note that in the first episode of financial globalization the histograms show fat tails, indicating many years of no access to international capital markets as well as many years in which countries can tap heavily international capital markets. The histograms for the second episode of financial globalization suggest a more uniform distribution with similar probabilities of no access, mild access, and high access to international capital markets over the 45 years of the second episode of financial globalization. The results from the Kolmogorov-Smirnov test are reported to the right of the histograms in Figure VII. Note that in all cases we can reject the null hypothesis of equality of the distributions at all conventional significance values. Again, this evidence points to a more stable international capital market since the 1970s when compared to the Gold Standard era.

\section{What Fuels Capital Flow Cycles?}

The previous section has shown that capital flow cycles have changed over time. Systemic capital flow bonanzas in Latin America have become much less dramatic and undistinguishable from the idiosyncratic ones. Busts have also changed, with Latin American countries being able to tap international capital markets more often in the aftermath of panics in the financial center. During the first episode of financial globalization, issuance in the aftermath of panics in the financial center is about half the issuance during busts in tranquil times. In contrast, during the second episode of financial globalization, the ability to tap international capital markets in the aftermath of a crisis in the financial center is far larger than in the aftermath of idiosyncratic bonanzas. What is driving these differences? Is it country-specific economic conditions? Or global factors? This section examines the drivers of these differences. First, it presents the data. Second, it examines the evolution of pull- and push-factors using event studies around the time of the peak of capital flow cycles in Latin American countries. Third, it studies the time-varying characteristics of monetary policy in the financial center and its impact on bonanzas and busts in the periphery in the two episodes of financial globalization.

\footnotetext{
${ }^{36}$ The Kolmogorov-Smirnov test is a nonparametric test of the equality of probability distributions. It can be used to compare a sample with a reference probability distribution (one-sample $\mathrm{K}-\mathrm{S}$ test) or to compare two samples (two-sample K-S test). The two-sample K-S test is a very useful nonparametric method for comparing two samples. It is sensitive to differences in both location and shape of the empirical cumulative distribution functions of the two samples.
} 


\section{V.A. The Data}

To capture country-specific shocks, the "pull-factors," I use two indicators: exports and the terms of trade of the Latin American countries. Since Latin American countries start tapping international capital markets in the early $19^{\text {th }}$ century and the official data on GDP starts later in the $20^{\text {th }}$ century, I capture economic activity using exports. Even so, data on exports are not readily available for the earlier part of the sample. In many cases, the database on exports is constructed using the data on imports from the most important trade-partner countries. For the terms of trade, I collect data on the prices of the most important exports of each of the countries in the sample and construct an export price index with weights capturing the time-varying share of each commodity export in total exports. I use the wholesale price index of the United Kingdom to capture prices of imports for the first episode of financial globalization and the consumer price index of the United States for the second episode of financial globalization. Figure VIII shows the evolution of country exports ${ }^{37}$ and the terms of trade. The first section shows the historical data while the second section shows the data since 1970.

To capture the "push factors," I use indicators of global liquidity and world economic activity. As it is traditional in this literature, I capture cycles of global liquidity with interest rates in the financial center. I use the bank rate in the United Kingdom for the first episode of financial globalization and the U.S. federal funds rate for the second episode of financial globalization. To capture global shocks to growth, I construct a series of world imports, which I capture with total imports of the financial centers of each episode. For the first episode, I use the imports of France, the United Kingdom, and the United States. For the second episode, I use the imports of Germany, the United Kingdom, and the United States. The evolution of these indicators is shown in Figure IX, first for the episode 1820-1931 and second for the episode 1970-2015..$^{38}$ The vertical lines in Figure IX identify the major panics in the financial centers over the two-hundred-year sample.

\footnotetext{
${ }^{37}$ Exports in Figure VIII are shown in British pounds for the first episode of financial globalization and in U.S. dollars for the second episode of financial globalization. For both episodes, exports are shown at constant prices. To estimate the values of exports at constant prices, I use the wholesale price index of the United Kingdom for the first episode of financial globalization and the consumer price index of the United States for the second episode of financial globalization. Similarly, in Figure IX, I estimate real world imports by deflating world imports in British pounds (US dollars) by the U.K. price index (U.S. price index).

${ }^{38}$ The database on macro fundamentals for the first episode of financial globalization was initially constructed for Kaminsky and Vega-García [2016]. The database on macro fundamentals for the second episode of financial globalization was constructed using data from The World Development Indicators Website (World Bank), the IMF database, and the Board of Governors of the Federal Reserve System database. See, the Appendix for a more detail explanation of data sources.
} 
For the first episode, the top panel shows the U.K. bank rate. This panel clearly shows that panics in the financial center are in part triggered by increases in interest rates. These hikes in interest rates are immediately reversed following the onset of the crisis. The bottom panel shows the evolution of world imports. It is clear from this panel that panics in the financial center are followed by persistent declines in world imports. It takes on average 7 years for world imports to recover to the pre-crisis levels.

For the second episode, the top panel in Figure IX shows the U.S. federal funds interest rate. While the federal funds interest rate captures well the cycles in monetary policy in the U.S. until the Subprime Crisis, once the federal funds rate hits the zero-lower-bound, the Federal Reserve starts conducting additional monetary easing via quantitative easing and forward guidance. Thus, Figure IX also shows Wu and Xia's [2016] shadow federal funds rate, which provides a single measure that takes into account the unconventional monetary policy measures implemented during the post-2008 period. Again, crises in the financial center are preceded by hikes in the federal funds rate. Interest rates increase about 11 percentage points in the years preceding the early 1980s U.S. banking crisis and about 4 percentage points before the onset of the Subprime Crisis. Like in the first episode of financial globalization, these hikes in interest rates are reversed at the onset of crises in the financial center, with interest rates declining by 10 percentage points in the aftermath of the early 1980s crisis and by about 8 percentage points (using the federal funds shadow rate) in the aftermath of the U.S. Subprime crisis. Importantly, I should note that the central bank policy responses around crises in the financial center during the second episode of financial globalization are far more dramatic and protracted when compared to those undertaken in the first episode of financial globalization when the actions of the central bank are constrained by the adherence to the Gold Standard. The bottom panel shows the evolution of world imports. Just like in the first episode of financial globalization, the evidence since 1970 indicates that the world economy slows down more abruptly in the aftermath of panics in the financial center.

\section{V.B. Event Studies}

To shed light on whether capital flow cycles may have different roots in the first and second episodes of financial globalization or during episodes with or without panics in the financial center, I examine these episodes separately. For both the first and the second episodes of financial globalization, Figure $X$ shows two set of panels: the panels to the left show the behavior of all the indicators during idiosyncratic capital flow cycles and the panels to the right show their behavior during systemic capital flow cycles. Figure $X$ shows both capital flow cycles as well as the evolution of country-specific factors (the "pull factors") as captured by the growth rates of (real) exports and the growth rate of the terms of 
trade. $^{39}$ I look at the behavior of each indicator for an interval of 10 years around the year of the peak in capital flows in each country $(t)$. In each panel, the solid line represents the average behavior of each indicator across all cycles while the dotted lines denote plus/minus one-standard-error bands around the average. For all the variables, the vertical axis in each figure records the percentage-point difference between the value of each indicator each year relative to its sample mean.

For the historical episode, the top two panels in Figure $\mathrm{X}$ show, as discussed before, that capital flow cycles are far more pronounced in the episodes around a crisis in the financial center. ${ }^{40}$ During systemic episodes, the average capital flow cycle peaks at 93 percent of exports while it only reaches about 38 percent of exports during idiosyncratic episodes. These more volatile capital flows are accompanied by more volatile growth rates of exports and the terms-of-trade. The middle two panels show the behavior of the growth rate of exports. Although both idiosyncratic and systemic capital flow bonanzas are accompanied by export growth, the export boom is substantially larger during idiosyncratic bonanzas. Importantly, the economies in Latin America collapse after crises in the financial center, with the growth rate of exports declining to about 5 percentage points below its sample mean. In contrast, there is no collapse of exports' growth in the aftermath of idiosyncratic capital flow bonanzas, with the growth rate during the capital flows busts being mostly the same as that of the growth rate over the entire episode. The bottom two panels show the terms-of-trade growth rate. Although both idiosyncratic and systemic bonanzas are accompanied by an improvement in the terms-of-trade of the borrowing countries, the terms-of-trade boom is more pronounced during systemic cycles, with the growth rate peaking at 2 percentage points above its sample mean. As with exports, the growth rate of the terms-of-trade collapses during the bust in capital flows during systemic episodes, with growth rates declining by 4 percentage points. In contrast, the fluctuations in the terms-of-trade growth rate around idiosyncratic capital flow cycles are far less pronounced, only declining by about 2 percentage points.

Figure $\mathrm{X}$ also shows the behavior of issuance, exports, and the terms of trade during the second episode of financial globalization. During this episode, the issuance cycles around crises in the financial center are very similar to those of an idiosyncratic nature with peaks reaching about 30 percent of exports. Interestingly, while capital flows in systemic episodes are not as volatile as those in the first episode of financial globalization, economic fundamentals booms and busts continue to be quite pronounced with

\footnotetext{
${ }^{39}$ As discussed before, for the first episode of financial globalization, I estimate real exports by deflating exports in British pounds with the U.K. price index. For the second episode of financial globalization, I deflate exports in U.S. dollars with the U.S. price index. Since exports and terms of trade are quite volatile, I estimate the growth rates of trend real exports and the growth rates of trend terms of trade.

${ }^{40}$ Capital flow cycles are measured relative to their sample mean.
} 
protracted downturns in the aftermath of panics in the financial center. For example, as shown in the right middle panel, the growth rate of exports declines from about 5 percentage points at the onset of the capital flow bonanzas to -7 percentage points during the bust. Similarly, the terms-of-trade growth rate declines about 8 percentage points from the peak of the boom to the trough of the bust. In contrast, during idiosyncratic capital flow cycles, export and terms of trade growth rates, after a short decline, recover during the bust in capital flows. Importantly, the evidence in Figure $\mathrm{X}$ suggests that the less pronounced capital flow cycles around panics in the financial center in the second episode of financial globalization cannot be explained by a dramatically more stable real business cycle in the borrowing countries.

Figure XI shows the evolution of the global factors (the "push factors") around the time of the peak in capital flow cycles in Latin America. This figure first shows two indicators of global liquidity. The first measure examines the evolution of the interest rate in the financial center around the peak of the capital flow cycles in Latin America. ${ }^{41}$ The second measure captures the aggressiveness and persistence of changes in monetary policy by estimating the 3-year average percent change in interest rates over the capital flow cycle. The last panels show the state of the world economy as captured by the growth rate of real imports of the financial centers. ${ }^{42}$ The indicators in the top and bottom panels in this figure are shown relative to their average over the sample.

For the historical episode, the evidence from the top four panels indicates that interest rate fluctuations in the U.K. around the peak of capital flow cycles are not very different from the average during the sample. Naturally, during the Gold Standard period, the Bank of England had less room to conduct cyclical monetary policy or to become the lender of last resort. The last panels capture economic activity in the financial centers. Again, as in Latin America, the fluctuations in economic activity in the financial centers are far more pronounced when the center itself is in crisis, with growth rates declining by 4 percentage points between booms and busts in these episodes. In contrast, idiosyncratic capital flow cycles in Latin America are accompanied by continuous growth in the world economy.

The second episode of financial globalization presents a different picture of monetary policy in the financial center during systemic and idiosyncratic capital flow cycles. As shown in the top two panels, interest rate fluctuations in the United States in episodes with no crisis in the financial center are quite

\footnotetext{
${ }^{41}$ Since any meaningful measures of expectations of inflation for the first episode of financial globalization are difficult to come by, I use nominal interest rates to capture changes in monetary policy during both episodes of financial globalization. The results are mostly unchanged when I use the real interest rate for the second episode of financial globalization.

${ }^{42}$ Again, as with exports, I estimate the growth rate of the trend of real imports.
} 
small and not statistically different from their average during the sample. In contrast, interest rate policy is more volatile at the onset of the U.S. banking crisis in the 1980s and the Subprime crisis in the 2000s. The Federal Reserve raises interest rates from about 1 percent in 2003 to 5 percent in 2007. The tightening in monetary policy in the late 1970s and early 1980s is even stronger, with the Federal Funds rate increasing from 5 percent in 1976 to 16 percent in 1981. Importantly, following the onset of the crisis in the financial center, interest rates are sharply reduced, with interest rates during the U.S. banking crisis in the 1980s declining from 16 percent in 1981 to 7 percent in 1986 and interest rates during the U.S. Subprime crisis declining from 5 percent in 2007 to a range of 0-0.25 percent (using the effective federal funds rate) and to -2.75 percent (using the Wu-Xia shadow federal funds rate). ${ }^{43}$ The sharp increases in interest rates in the years preceding financial crises in the United States cut short the booms in international issuance while the extremely easy monetary policy in the years following the crisis in the financial center drastically ameliorates the collapse in international capital flows. Interestingly, global economic activity volatility in the second episode of financial globalization continues to be as pronounced around panics in the financial center as it is during the first episode of financial globalization, with the growth rate of world imports declining about 5 percentage points from peak to trough during the second episode of financial globalization.

\section{V.C. Monetary Policy in the Financial Centers: Then and Now}

This section first tests the time-varying characteristics of monetary policy in the financial center in the two episodes of financial globalization and then studies its effect on the amplitude of capital flow booms and busts in the periphery. Again, I capture monetary policy in the financial center with the U.K. bank interest rate during the first episode of financial globalization and the U.S. federal funds interest rate during the second episode of financial globalization.

Table III shows the interest rate fluctuations around times of panics in the financial center in the two episodes of financial globalization and compares them to the average fluctuations of each of the episodes. The top panel shows two measures of volatility of interest rates: the standard deviation and the coefficient of variation. The clear message of this panel is that interest-rate volatility during the first episode of financial globalization does not change during crises. This is not the case since the 1970s. In

\footnotetext{
${ }^{43}$ All the estimations in the paper report the evidence using the effective U.S. federal funds interest rate. All the estimations were also performed using the combined federal funds interest rate: the effective federal funds interest rate for the 1970-2009 period and the shadow federal funds interest rate for 2010-2015. The results with the combined interest rate are similar to those just using the effective federal funds interest rate.
} 
this episode, volatility during crises in the financial center increases about 25 percent, suggesting more drastic changes in monetary policy when the financial center is in distress.

The top panel in Table III only examines annual fluctuations in interest rates. However, around times of financial panics, annual changes in interest rates can become not only far more pronounced but also highly protracted. To evaluate the extent of the range and persistence of interest rate changes around panics in the financial center, the bottom panel compares average percent changes of interest rates over 5-year intervals, both for crisis times and for the whole sample. As shown in the first two columns, panics are preceded by interest rate hikes to rein in the credit booms preceding the crises and are followed by interest rate cuts to inject liquidity after the panic in both episodes of financial globalization. But are these changes unusual? To examine whether the changes in monetary policy around a panic in the financial center are more drastic and protracted than in normal times, I estimate an annual series of 5-year changes in interest rates over the whole sample. I then divide these 5-year changes into two series: one with only positive 5-year changes and the other with just negative 5-year changes. The average of the positive and negative strings over the whole sample are reported in columns 3 and 4. Columns 5 and 6 show the p-values of testing the null hypothesis of equality of these positive (negative) 5-year average changes in crisis times and those positive (negative) 5-year average changes over the whole sample with the alternative hypothesis that hikes (cuts) in interest rates predating (following) the panic are on average larger than the ones over the whole sample. ${ }^{44}$ Interestingly, as shown by the $p$ values, during the first episode of financial globalization, hikes (cuts) of interest rates around the onset of a crisis in the financial center are not statistically different from the positive (negative) changes over the whole sample. In contrast, during the second episode of financial globalization, hikes preceding crises are on average 2.7 times larger than the average hike during the whole sample, with the null hypothesis rejected at all conventional significance levels. Again, during the second episode of financial globalization, cuts in interest rates in the aftermath of crises are on average 1.8 times larger than the average decline during the whole sample, with the null hypothesis rejected at all conventional significance levels.

The question now is whether the time-varying monetary policy can explain the stabilization of capital flow cycles around panics in the financial center since the collapse of the Bretton Woods System. Table IV uses regression analysis to capture the effect of monetary policy in the financial center on the amplitude of bonanzas and busts. The estimates also control for other push and pull factors. The dependent variables of the regressions are the amplitude of the bonanzas and the busts as a share of

\footnotetext{
${ }^{44}$ Since by construction these series are serially correlated and as shown in Table 3 they are heteroscedastic, the tstatistic and $\mathrm{p}$-value have to be made robust to serial correlation and heteroscedasticity using HAC standard errors.
} 
exports shown in Table II. As in the event studies in Figure X, country-specific factors are the growth rate of exports and the terms of trade. As in Figure XI, I capture monetary policy with changes in interest rates. I also control for the state of the global economy with the growth rate of world imports. The top panel in Table IV shows the estimations explaining bonanzas while the bottom panel shows the estimations explaining busts. Since I want to explain issuance over the cycle, the explanatory variables are measured as an average around the peak of the cycle (I use 3-year averages). For the regression explaining the amplitude of bonanzas, the 3-year averages include the year of the peak of the cycle and the two years prior to the peak. For the busts, the 3-year averages include the year of the beginning of the bust and the following two years. In both panels, the indicator of monetary policy in the financial center is interacted with dummy variables to capture the possible time-varying effects of monetary policy over the two episodes of financial globalization and across the two varieties of capital flow cycles (those cycles coinciding with panics in the financial center and those occurring during tranquil times). The dummy "First Episode" ("Second Episode") is equal to one for all the bonanzas and busts during the first (second) episode of financial globalization and zero otherwise. The dummy "Systemic Cycle" ("Idiosyncratic Cycle") is equal to 1 for all the bonanzas and busts coinciding with a crisis in the financial center (occurring during tranquil times in the financial center) and zero otherwise.

The estimates in Table IV indicate that monetary policy in the financial center only matters during the second episode of financial globalization for cycles around panics in the financial center. It is in those times that drastic and protracted tightenings (easings) in monetary policy reduce (increase) issuance during the bonanzas (busts). Importantly, the estimates indicate that the effects of monetary policy in those times are not only statistically significant but also economically significant: The severe monetary policy changes in times of crisis during the second episode of financial globalization (captured by a onestandard deviation of the 3-year growth in the Federal Reserve interest rate) can explain on average about 43 percent of the decline in issuance during bonanzas and about 38 percent of the increase in issuance during busts relative to those observed during the first episode of financial globalization.

\section{Conclusions}

Boom-bust cycles in international capital flows are hardy perennials. Financial globalization first erupts in the aftermath of the Napoleonic wars with London at its center. The next 120 years are witnesses to a massive expansion of financial flows to every corner of the globe not just from London but also from Paris, Frankfurt, Berlin, and New York, the new financial capitals of the world. Financial globalization then collapses in the aftermath of the Great Depression when countries around the world 
erect barriers to international capital flows. It takes about 40 years for capital flows to restart. The collapse of the Bretton Woods System heralds the restart of financial globalization. With floating exchange rates, countries can regain monetary autonomy without resorting to capital account controls. Barriers to capital flows begin to be dismantled first in the financial centers and then in the periphery. Financial globalization erupts again and so do boom-bust cycles in international capital flows.

The restart of financial globalization in the 1970s has fueled an immense research on capital flows. One of the most studied topics are the triggers of booms and busts, with a focus on the pull and push factors and whether cycles are excessive and trigger financial crises. This paper contributes to this literature with an important twist. It examines capital flow cycles since the restart of financial globalization in the 1970s and compares these cycles with those of the first episode of financial globalization. This new database allows me to study two very prominent and debated topics in international finance: the role of monetary policy and financial panics in the financial center on capital flow cycles to the emerging periphery. This paper also forms part of a new area of research on cycles of government indebtedness and banking credit booms spanning two centuries. ${ }^{45}$

While the analysis of capital flows using a larger sample of countries is clearly necessary ${ }^{46}$ the evidence from Latin America for the two episodes of financial globalization strongly indicates that capital flow bonanzas to the emerging periphery are far less pronounced since the 1970 s than those observed during the first episode of financial globalization. Moreover, it is not just about booms. Busts are also more dramatic during the first episode of financial globalization, with countries around the world losing complete access to international capital markets for many years. At the core of these differences are the systemic boom-bust capital flow cycles to the emerging periphery as defined as those cycles that coincide with crises in the financial center. In contrast, idiosyncratic boom-bust cycles to the emerging periphery are more similar in the two eras of financial globalization. The question is what drives these changes in the characteristics of systemic capital flow cycles. The evidence presented above suggests that the change in the monetary regime in the financial centers is at the core of these changes. Without the constraints of the adherence to the Gold Standard, monetary policy in the financial center becomes not only cyclical but also time-varying, with far more marked shifts implemented amid economic and financial distress in the financial center. For example, the change in the U.S. monetary policy in the late 1970 s and early

\footnotetext{
${ }^{45}$ See, for example, Jordà, Schularick, and Taylor [2011], Reinhart and Rogoff [2011], and Schularick and Taylor [2013].

${ }^{46}$ I am finalizing the data on issuance and macro-economic indicators for about twenty other major international borrower countries for the first episode of financial globalization to compare the cycles of capital flows then and now.
} 
1980s is not only preceded by high inflation but also by a boom in international lending with U.S. commercial banks at its core. In this environment, the sharp hikes in interest rates in the United States wreak havoc on international capital markets as basically all international lending at that time is contracted at a floating interest rate. Many debtor countries are forced to reschedule their debts with the commercial bank creditors, substantially damaging banks' balance sheets. With banks' exposure to the developing countries significantly exceeding the banks' total capital, the odds of a major world financial crisis increase. To avoid a full-blown crisis, monetary and regulatory policies are implemented to keep the debtor countries servicing their debts to the commercial banks in the financial centers. Interest rates are sharply reduced, commercial banks involuntary lending policies to debtor countries are introduced, and lax prudential standards are applied to banks heavily exposed to developing countries to allow them to carry those loans at book value even when they are heavily discounted in the secondary markets. Similar drastic policy measures are also implemented before and after the U.S. Subprime crisis: the federal funds rate is increased from 1 percent to 5 percent in the mid-2000s and is rapidly reduced to 0-0.25 percent following the onset of the crisis. This crisis also triggers an unprecedented expansion of the U.S. money base. These policies cut short international capital flow bonanzas and substantially increase international liquidity during the busts in international capital flows following the crisis in the financial center.

Importantly, even with this plethora of policies implemented to stabilize financial markets before and after a crisis in the financial center, recessions in the financial center and the emerging periphery (as captured in Figures $\mathrm{X}$ and $\mathrm{XI}$ ) are as pronounced now as they were during the first episode of financial globalization. Many suggest that at the core of dramatic economic slowdowns in the aftermath of a panic in the financial center during the Gold Standard episode is the inability of central banks to be a lender of last resort and use monetary policy as a stabilizing tool. But is the movement to cyclical monetary policy and the persistent injection of liquidity in the aftermath of a crisis in the financial center since the 1970s too much of a good thing? Does this increase in leverage in the financial center contribute to its economic slowdown in the aftermath of financial distress? The debate is still ongoing, with both supporters and detractors of these policies. But what about the emerging periphery? During the first episode of financial globalization, the end of the systemic capital flow bonanzas to the emerging periphery is followed by waves of defaults. Many argue that these defaults, amid a collapse in international liquidity, are at the core of the sharp slowdown in economic activity of the debtor countries. Since the restart of globalization in the 1970s, the experiences in the emerging periphery are diverse. Still, a common thread is the increase of leverage in the aftermath of distress in the financial center. While the bonanzas of the 1970s and early 
1980s are followed by early defaults in the periphery, continuous renegotiations and banks' involuntary lending avoid debt forgiveness for about a decade, with leverage in the periphery increasing dramatically in the 1980s. Many argue these lingering renegotiations and injections of liquidity for the debtor countries to be current on interest payments are at the core of the lost decade in Latin America. The experience in the aftermath of the Subprime crisis is different. Developing countries do not default and continue tapping international capital markets in the aftermath of the panic in 2008, with leverage increasing in the emerging world this time around too. Is this at the core of the slowdown in the emerging periphery ${ }^{47}$

Latin American countries are the quintessential prototype of emerging markets making the findings in this paper quite general. Still, a further analysis of a larger sample of countries including developed economies could help to untangle the route through which financial crises with the financial center at its epicenter are transmitted to the periphery during both episodes of financial globalization.

\footnotetext{
${ }^{47}$ The seemingly lack of stabilizing characteristics of macro-policies suggested by the evidence in Figures $\mathrm{X}$ and $\mathrm{XI}$ is closely related to the findings in Romer [1986a and 1986b]. In those papers, Romer re-estimates the series of the US industrial production and unemployment rates and finds that real cycles before and after WWII are statistically undistinguishable, putting into question the effectiveness of the post-WWII government stabilization policy on the real business cycle. I thank Maury Obstfeld for bringing to my attention the similarity of the findings.
} 


\section{Appendix 1 \\ Data Sources: 1820-1931 and 1970-2015}

\section{International Issuance and Default Restructurings}

Barandiarán Edgardo, and Leonardo Hernández, "Origins and Resolution of a Banking Crisis: Chile 198286." Central Bank of Chile Working Paper No. 57, 1999.

Bazant, Jan, Historia de la Deuda Exterior de México, 1823-1946, (Guanajuato: Mexico El Colegio de Mexico, 1968).

Beers, David, and Jamshid Mavalwalla, "Database of Sovereign Defaults, 2017," Bank of Canada Technical Report No. 101, 2017.

Bloomberg L.P., Bloomberg Terminal, New York, NY.

Boughton, James, Silent Revolution: The International Monetary Fund, 1979-1989, (Washington, D.C: International Monetary Fund, 2001).

Burdett's Stock Exchange Official Intelligence, various issues.

Bussière, Eric, Paribas, Europe and the World, 1872-1992, (Antwerp, Belgium: Fonds Mercator, 1992).

Bustillo, Inés, and Helvia Velloso, "Debt Financing Rollercoaster: Latin American and Caribbean Access to International Bond Markets Since the Debt Crisis, 1982-2012." Economic Commission for Latin America and the Caribbean, Santiago, Chile, 2013.

Camacho, Vicente, Resumen Histórico sobre la Deuda Exterior de Colombia del 3 por 100 (Bogota, Colombia: Imprenta Eléctrica, 1914).

Casasus, Joaquin Demetrio, Historia de la Deuda Contraída en Londres (Mexico: Imprenta del Gobierno en Palacio, 1885).

Clarke, Hyde, Sovereign and Quasi Sovereign States: Their Debts to Foreign Countries (London: Effingham Wilson, 1878).

Confederation of Foreign Bondholders, Annual Reports, London, 1876-1988

Costeloe, Michael, Deuda Externa de México: Bonos y Tenedores de Bonos, 1824-1888 (Mexico: Fondo de Cultura Económica, 2007).

Credit Lyonnais Archive, Paris, France.

Dawson, Frank, The First Latin American Debt Crisis: The City of London and the 1822-25 Loan Bubble (New Haven and London: Yale University Press, 1990).

Dealogic Analytics Database.

De Castro Carreira, Liberato, História Financeira e Orçamentária do Império no Brasil (Rio de Janeiro, Brasil: Fundação Casa de Rui Barbosa, Ministério da Educação e Cultura, 1980).

Desjardins, Bernard, Michel Lescure, Roger Nougaret, Alain Plessis, and André Straus, Le Crédit Lyonnais, 1863-1986, (Genève: Librairie Droz S.A.,2003).

Fenn, Charles, Compendium of the English and Foreign Funds with Statements of All Debts and Revenues of All Nations also of the Principal Joint Stock Companies (London: E. Wilson, various issues).

Foreign Bondholders Protective Council, Inc., Annual Reports, New York, NY., various issues.

Ferguson, Niall, The House of Rothschild, 2 volumes (London/New York: Penguin Press, 1998-1999).

Fundação Instituto Brazileiro de Geografia e Estadistica, Estatísticas Históricas do Brazil: Séries Econômicas, Demográficas e Sociais de 1550 a 1988 (Rio de Janeiro, Brazil: IBGE, 1990).

German Statistics Yearbook, various issues.

German Economist, various issues

Germany's Stock Exchange Calendar and Securities Manual, various issues.

Gille, Bertrand, Histoire de la Maison Rothschild (Genève, Switzerland: Librairie Droz, 1967).

Goetzman, William, and Geert Rouwenhorst, The Financial Innovations that Created Modern Capital Markets (Oxford: Oxford University Press, 2005). 
Investors' Monthly Manual: A Newspaper for Investors, London, 1865-1914, Institute of International Finance, Inc., Survey of Debt Restructuring by Private Creditors, 2001.

Jenks, Leland, The Migration of British Capital to 1875 (USA: Harper \& Row Publishers, Inc., 1971).

Kaminsky, Graciela and Pablo Vega-García, "Systemic and Idiosyncratic Sovereign Debt Crises" Journal of the European Economic Association, 14 (2016), 80-114. Online Appendix.

Kaminsky, Graciela, "Two Hundred Years of International Borrowing Cycles: A New Historical Database," NBER Working Paper No. 22819, 2016.

Kimber, Albert, Kimber's Records on Government Debts and Other Foreign Securities (New York: A.W. Kimber and Company, 1922).

Larraín, Felipe, and Andrés Velasco, "Can Swaps Solve the Debt Crisis: Lessons from the Chilean Experience," Princeton Studies in International Finance No. 69, 1990.

L'Economiste Européen, various issues.

London Stock Exchange, The Stock Exchange Official Yearbook, London, various years.

Moody, John, Moody's Analyses of Investments and Security Rating Books; Government and Municipal Investments, New York, NY, 1919-1955.

New York Stock Exchange, NYSE Listing Statements, NY, New York, various issues.

Palacios Moreyra, Carlos, La Deuda Anglo Peruana: 1822-1890 (Lima, Perú: Librería Studium, 1983).

Payno, Manuel, México and Her Financial Questions with England, Spain, and France: Report by Order of the Supreme Constitutional Government of the Mexican Republic, (Mexico: Ignacio Cumplido, 1862).

International Monetary Fund, Private Market Financing for Developing Countries, Washington, D.C., various issues,

Michie, Ranald, The London Stock Exchange: A History (Oxford, Great Britain: Oxford University Press, 1999).

Paris Stock Exchange, Annual Report of Securities Listed on the Bankers' Market. various issues.

Prospectuses of Bonds and Shares issued in various Financial Centers, 1820-1931.

Rippy, J. Fred, British Investment in Latin America, 1822-1949 (New York: Arno Press, A New York Times Company, 1977).

Rothschild Archive, London, United Kingdom.

Stallings, Barbara, Banker to the Third World: US Portfolio Investment in Latin America,1900-1986 (San Francisco: University of California Press, 1987).

Statist, London, 1878-1914.

Sturzenegger, Federico, and Jeromin Zettelmeyer, "Haircuts: Estimating Investor Losses in Sovereign Debt Restructurings, 1998-2005," IMF Working Paper 05/137, 2005.

Suter, Christian, Debt Cycles in the World Economy: Foreign Loans, Financial Crises, and Debt Settlements, 1820-1990 (Boulder, Colorado: Westview Press, Inc., 1992).

The Baring Archive, London, United Kingdom.

The Fitch Publishing Company, Inc. The Fitch Record of Government Debts, various issues.

The London Economist, various issues.

The Official Paris Stock Exchange Annual Report, various issues.

The World Bank, Borrowing in International Capital Markets, Washington, D.C., various issues.

The World Bank, various issues, Global Development Finance. Washington, D.C., various issues.

Times, London, 1820-1931.

Thomson Reuters, Datastream.

Tomz, Michael, Reputation and International Cooperation: Sovereign Debt across Three Centuries, (Princeton, New Jersey: Princeton University Press, 2007).

Turlington, Edgar, Mexico and Her Foreign Creditors, (New York: Columbia University Press, 1930).

U.S. Department of Commerce, various issues, Trade Promotion Series, Washington, D.C. 
Waibel, Michael, Sovereign Defaults before International Courts and Tribunals (Cambridge, England: Cambridge Studies in International and Comparative Law, Cambridge University Press, 2011).

Winkler, Max, Foreign Bonds: An Autopsy (Philadelphia: Roland Sway Co., 1933).

World Debt Tables: External Finance for Developing Countries, The World Bank, various issues.

Wynne, William, State Insolvency and Foreign Bondholders, Selected Case Histories of Governmental Foreign bond Defaults and Debt Readjustments, Volume II, (New Haven, Yale University Press, 1951).

Ziegler, Philip, The Sixth Great Power: The History of One of the Greatest of All Banking Families, The House of Baring, 1762-1929 (New York: Alfred A. Knopf, 1988).

\section{Exports, Imports, Terms of Trade, Interest Rates, and Prices: 1820-1931 and 1970-2015}

\section{II.1 Exports}

\section{Argentina}

Commerce and Navigation of the United States, Bureau of Statistics, Treasury Department, various issues. Tableau Genéral du Commerce de la France avec ses Colonies et les Puissances Étrangeres, Administration de Douanes, various issues.

The House of Commons, Parliamentary Papers, 1801-1900, London, United Kingdom.

The Annual Statement of Trade and Navigation of the United Kingdom with Foreign Countries and British Possessions, Customs Establishment Statistical Office. Various issues.

Dos Siglos de Economía Argentina 1810-2004. Historia Argentina en Cifras, Orlando Ferreres, Table 8.1.1 International Monetary Fund, World Economic Outlook Database.

\section{Brazil}

Commerce and Navigation of the United States, Bureau of Statistics, Treasury Department, various issues. Tableau Genéral du Commerce de la France avec ses Colonies et les Puissances Étrangeres, Administration de Douanes, various issues.

The House of Commons, Parliamentary Papers, 1801-1900, London, United Kingdom.

The Annual Statement of Trade and Navigation of the United Kingdom with Foreign Countries and British Possessions, Customs Establishment Statistical Office. Various issues.

Estatísticas Históricas do Brazil: Séries Econômicas, Demográficas e Sociais de 1550 a 1988, Fundação Instituto Brazileiro de Geografia e Estatistica. Sector Externo: Gustavo Henrique Barroso Franco (Departamento de Economia, Pontificia Universidade Catolica PUC-RJ). Table 11.1

International Monetary Fund, World Economic Outlook Database.

\section{Chile}

Economía Chilena 1810-1995 Estadísticas Históricas; Matias Braun, Ignacio Briones, and José Díaz, in www.economia.puc.cl. Table V.I.1

International Monetary Fund, World Economic Outlook Database.

\section{Colombia}

Commerce and Navigation of the United States, Bureau of Statistics, Treasury Department, various issues.

Tableau Genéral du Commerce de la France avec ses Colonies et les Puissances Étrangeres, Administration de Douanes, various issues.

The House of Commons, Parliamentary Papers, 1801-1900, London, United Kingdom.

The Annual Statement of Trade and Navigation of the United Kingdom with Foreign Countries and British Possessions, Customs Establishment Statistical Office, various issues. 
Memoria sobre la Monedación de Oro I Plata by José Manuel Restrepo.

Compendio de Estadísticas Históricas de Colombia, Miguel Urrutia and Mario Arrubla, Universidad Nacional de Colombia, Bogotá, 1970. Page 108.

International Monetary Fund, World Economic Outlook Database.

\section{Mexico}

Commerce and Navigation of the United States, Bureau of Statistics, Treasury Department, various issues. Tableau Genéral du Commerce de la France avec ses Colonies et les Puissances Étrangeres, Administration de Douanes, various issues.

The House of Commons, Parliamentary Papers, 1801-1900, London, United Kingdom.

The Annual Statement of Trade and Navigation of the United Kingdom with Foreign Countries and British Possessions, Customs Establishment Statistical Office. Various issues.

Estadísticas Históricas de México Tomo II, Instituto Nacional de Estadistica, Geografía e Informática, INEGI. Table 18.1

Inés Herrera Canales El Comercio Exterior de México 1821-1873, 1977.

University of Oxford, Oxford Latin American Economic History Database

International Monetary Fund, World Economic Outlook Database

Peru:

Commerce and Navigation of the United States, Bureau of Statistics, Treasury Department, various issues. Tableau Genéral du Commerce de la France avec ses Colonies et les Puissances Étrangeres, Administration de Douanes, various issues.

The House of Commons, Parliamentary Papers, 1801-1900, London, United Kingdom.

The Annual Statement of Trade and Navigation of the United Kingdom with Foreign Countries and British Possessions, Customs Establishment Statistical Office. Various issues.

Compendio de Historia Económica del Perú, Carlos Contrera (Editor), Banco Central de la Reserva del Perú, 2010.

Price and Quantum Estimates of Peruvian Exports 1830-1962, Shane J. Hunt, Princeton University. Historia de la República del Perú 1822-1933, Jorge Basadre, Editorial Universitaria, 1965.

Anuario Estadístico del Perú, 1944-1945, Ministerio de Hacienda y Comercio. Dirección Nacional de Estadística.

International Monetary Fund, World Economic Outlook Database.

\section{Uruguay}

Anales Históricos del Uruguay, Eduardo Acevedo, Casa A. Barreiro y Ramos, S.A., Montevideo, 1933 Estadisticas Históricas del Uruguay 1900-1950, Benjamín Nahum, Universidad de la República, 2007. International Monetary Fund, World Economic Outlook Database.

\section{II.2 Imports}

\section{France}

Tableau Genéral du Commerce de la France avec ses Colonies et les Puissances Étrangeres, Administration de Douanes, various issues.

International Monetary Fund, World Economic Outlook Database.

\section{Germany}

International Monetary Fund, World Economic Outlook Database. 


\section{United Kingdom}

The House of Commons, Parliamentary Papers, 1801-1900, London, United Kingdom.

The Annual Statement of Trade and Navigation of the United Kingdom with Foreign Countries and British Possessions, Customs Establishment Statistical Office. Various issues.

International Monetary Fund, World Economic Outlook Database.

\section{United States}

Commerce and Navigation of the United States, Bureau of Statistics, Treasury Department, various issues. International Monetary Fund, World Economic Outlook Database.

\section{II.3 Commodity Prices, Export Shares, and Price Indices}

Bezanson, R. D. Gray, and M. Hussey, Wholesale Prices in Philadelphia 1784-1861: Series of Relative Monthly Prices (Philadelphia: University of Pennsylvania Press., 1937).

Gayer, A.D., W.W. Rostow, and A.J. Schwartz, Microfilmed Supplement to Volumes I and II of The Growth and Fluctuation of the British Economy 1790-1850 (Oxford: Clarendon Press, 1953).

International Financial Statistics, International Monetary Fund. Online Database

Jastram, Roy, Silver: The Restless Metal (New Jersey: Wiley, 1981).

Sauerbeck, Augustus "Prices of Commodities and Precious Metals," Journal of the Statistical Society of London, various issues.

U.S. Department of Commerce, Historical Statistics of the United States from Colonial Times to 1970, Bureau of the Census.

Manthy, Robert, and Joan Tron, Natural Resources Commodities- A Century of Statistics: Prices, Output, Consumption, Foreign Trade, and Employment in the United States, 1870-1973 (Baltimore: Johns Hopkins University Press, 1978).

Mitchell, B.R., British Historical Statistics, (Cambridge, England: Cambridge University, Press, 1988).

Mitchell, B. R., International Historical Statistics Europe, 1750-2007 (United Kingdom: Palgrave MacMillan, 1992).

Mitchell, B. R., International Historical Statistics the Americas, 1750-2007 (United Kingdom: Palgrave MacMillan, 1992).

\section{II.4 Interest Rates}

Federal Reserve Bank of St. Louis, FRED Economic Data, https://fred.stlouisfed.org/

Homer, Sidney, and Richard Sylla, A History of Interest Rates, Fourth Edition (New Jersey. USA: John Wiley and Sons, Inc., 2005).

International Financial Statistics, International Monetary Fund, Online Database.

Wu, Jing, and Fan Xia, 2016, "Measuring the Macroeconomic Impact of Monetary Policy at the Zero Lower Bound," Journal of Money, Credit, and Banking, 48 (2016), 253-291. 


\section{References}

Acharya, Viral, and Philipp Schnabl, "Do Global Banks Spread Global Imbalances? Asset-Backed Commercial Paper During the Financial Crisis of 2007-09," IMF Economic Review, 58 (2010), 3773.

Arteta, Carlos, and Galina Hale, "Currency Crises and Foreign Credit in Emerging Markets: Credit Crunch or Demand Effect?" European Economic Review, 53 (2009), 758-774.

Barro, Robert, "Rare Disasters and Asset Markets in the Twentieth Century," The Quarterly Journal of Economics, 121 (2006), 823-866.

Bordo, Michael, and Antu Murshid, "The International Transmission of Financial Crises before World War II: Was there Contagion?" Prepared for UNU/WIDER conference on Financial Contagion Helsinki, mimeo, 1999.

Borio, Claudio, and Piti Disyatat, “Global Imbalances and the Financial Crisis: Link or no Link?," BIS Working Papers 346, 2011.

Broner, Fernando, Tatiana Didier, Aitor Erce, and Sergio Schmukler, "Gross Capital Flows: Dynamics and Crises," Journal of Monetary Economics, 60 (2013), 113-133.

Bruno, Valentina, and Hyun Song Shin, "Capital Flows and the Risk-Taking Channel of Monetary Policy", Journal of Monetary Economics, 71 (2015), 119-132.

Bussière, Matthieu, Julia Schmidt, and Natacha Valla, "International Financial Flows in the New Normal: Key Patterns (and Why We Should Care)," Policy Brief CEPII No. 10, 2016.

Bry, Gerhard and Charlotte Boschan, Cyclical Analysis of Time Series: Selected Procedures and Computer Programs (New York: Columbia University Press, 1971).

Calvo, Guillermo, Leonardo Leiderman, and Carmen Reinhart, "Capital Inflows and Real Exchange Rate Appreciation in Latin America: The Role of External Factors," International Monetary Fund Staff Papers, 40 (1993), 108-151.

Cerutti, Eugenio, Galina Hale, and Camelia Minoiu, "Financial Crises and the Composition of Cross-Border Lending," Journal of International Money and Finance, 52 (2015), 60-81.

Cottrell, Philip, "Established Connection and New Opportunities. London as an International Financial Centre, 1914-1958" in Youssef Cassis and Éric Bussière, eds., London and Paris as International Financial Centres in the Twentieth Century (Oxford: Oxford University Press, 2005).

de la Torre, Augusto, Juan Carlos Gozzi, and Sergio Schmukler, "Capital Market Development: Whither Latin America?" in Sebastian Edwards and Márcio Garcia, eds., Financial Markets Volatility and Performance in Emerging Markets (Chicago: University of Chicago Press, 2008).

Eichengreen, Barry, "Historical Research on International Lending and Debt," The Journal of Economic Perspectives, 5 (1991), 149-169.

Eichengreen, Barry, "Trends and Cycles in Foreign Lending," in Horst Siebert, ed., Capital Flows and the World Economy, (Kiel: World Institute of Economics, 1992).

English, William, "Understanding the Costs of Sovereign Default: American State Debts in the 1840's," American Economic Review, 86 (1996), 259-275.

Fernández-Arias, Eduardo, "The New Wave of Private Capital Inflows: Push or Pull?" Journal of Development Economics, 48 (1996), 389-418

Forbes, Kristin and Francis Warnock, "Capital Flow Waves: Surges, Stops, Flight, and Retrenchment," Journal of International Economics, 88 (2012), 235-251.

Ghosh, Atish, Mahvash Qureshi, Jun Kim, and Juan Zalduendo, "Surges," Journal of International Economics, 92 (2014), 266-285.

Gadanecz, Blaise, "The Syndicated Loan Market: Structure, Development, and Implications," BIS Quarterly Review, December (2004), 75-89. 
Jorgensen, Erika, and Jeffrey Sachs, "Default and Renegotiation of Latin American Foreign bonds in the Interwar Period, in Barry Eichengreen and Peter Lindert, eds, A Long Run Perspective on the Debt Crisis (Cambridge: MIT Press, 1989).

Harding, Don, and Adrian Pagan, "Dissecting the Cycle: A Methodological Investigation," Journal of Monetary Economics, 49 (2002), 365-381.

Harding, Don, and Adrian Pagan, "Synchronization of Cycles," Journal of Econometrics, 132 (2006), 59-79.

Jordà, Òscar, Katharina Knoll, Dmitry Kuvshinov, Moritz Schularick, and Alan Taylor, "The Rate of Return on Everything, 1870-2015," NBER Working Paper No. 24112, 2017.

Jordà, Òscar, Moritz Schularick, and Alan Taylor, 2011, "Financial Crises, Credit Booms, and External Imbalances: 140 Years of Lessons," IMF Economic Review, 59 (2011), 340-378.

Kaminsky, Graciela, and Sergio Schmukler, "Short-Run Pain, Long-Run Gain: Financial Liberalization and Stock Market Cycles," Review of Finance, 12 (2008), 253-292.

Kaminsky, Graciela and Pablo Vega-García, "Systemic and Idiosyncratic Sovereign Debt Crises" Journal of the European Economic Association, 14 (2016), 80-114.

Marichal, Carlos, A Century of Debt Crises in Latin America (New Jersey: Princeton University Press, 1989).

Milesi-Ferretti, Gian Maria, and Cédric Tille, "The Great Retrenchment: International Capital Flows during the Global Financial Crisis," Economic Policy, 66 (2010), 285-330.

Miranda-Agrippino, Silvia, and Hélène Rey, "World Asset Markets and the Global Cycle," mimeo, 2015.

Obstfeld, Maurice, "Does the Current Account Still Matter?" American Economic Review: Papers \& Proceedings, 102 (2012), 1-23.

Reinhart, Carmen, and Kenneth Rogoff, 2009, This Time is Different: Eight Centuries of Financial Folly (Princeton: Princeton University Press, 2009).

Reinhart, Carmen and Vincent Reinhart, "Capital Flow Bonanzas: An Encompassing View of Past and Present," in Jeffrey Frankel and Christopher Pissarides, eds., NBER Book Series NBER International Seminar on Macroeconomics (Chicago: University of Chicago Press, 2009).

Reinhart, Carmen, Vincent Reinhart, and Christoph Trebesch, "Capital Flow Cycles: A Long, Global View," mimeo, 2017.

Rey, Hélène, "Dilemma not Trilemma: The Global Financial Cycle and Monetary Policy Independence, NBER Working Paper No. 21162, 2015.

Romer, Christina, 1986a, "Is the Stabilization of the Postwar Economy a Figment of the Data," American Economic Review, 76 (1986a), 314-334.

Romer, Christina, "Spurious Volatility in Historical Unemployment Data," Journal of Political Economy, 94 (1986b), 1-37.

Sachs, Jeffrey, "Managing the LDC Debt Crisis," Brookings Papers on Economic Activity, 2 (1986), 397-431.

Sachs, Jeffrey, and Harry Huizinga, "U.S. Commercial Banks and the Developing-Country Debt Crisis, Brookings Papers on Economic Activity, 2 (1987), 555-606.

Schularick, Moritz and Alan Taylor, 2013, "Credit Booms Gone Bust: Monetary Policy, Leverage Cycles, and Financial Crises, 1870-2008," American Economic Review, Vol. 102 (2), pages 1029-1061.

Stallings, Barbara, Banker to the Third World: U.S. Portfolio Investment in Latin America, 1900-1986, Berkerly: University of California Press, 1987).

Shin, Hyun Song, "Global Banking Glut and Loan Risk Premium," IMF Economic Review, 60 (2012), 155192.

Stone, Irving, The Global Export of Capital from Great Britain, 1865-1914: A Statistical Survey, (London: Palgrave-MacMillan Press Ltd., 1999).

Sturzenegger, Federico, and Jeromin Zettelmeyer, Debt Defaults and Lessons from a Decade of Crises, (Cambridge, Massachusetts: MIT Press, 2006).

Wu, Jing and Fan Xia, 2016, "Measuring the Macroeconomic Impact of Monetary Policy at the Zero Lower Bound," Journal of Money, Credit, and Banking, Vol. 48 (2-3), pages 253-291. 
Table I

International Capital Flow Cycles: Duration

1820-1931

\begin{tabular}{|c|c|c|c|c|c|c|}
\hline \multirow{2}{*}{ Country } & \multicolumn{3}{|c|}{ Cycles } & \multicolumn{3}{|c|}{ Duration } \\
\hline & Beginning & Peak & End & Booms & Busts & Whole Cycle \\
\hline \multirow{5}{*}{ Argentina } & 1823 & 1824 & 1859 & 2 & 35 & 37 \\
\hline & 1860 & 1872 & 1877 & 13 & 5 & 18 \\
\hline & 1878 & 1888 & 1893 & 11 & 5 & 16 \\
\hline & 1894 & 1910 & 1919 & 17 & 9 & 26 \\
\hline & 1920 & 1927 & 1972 & 8 & 45 & 53 \\
\hline \multirow{6}{*}{ Brazil } & 1823 & 1825 & 1856 & 3 & 31 & 34 \\
\hline & 1857 & 1864 & 1869 & 8 & 5 & 13 \\
\hline & 1870 & 1887 & 1891 & 18 & 4 & 22 \\
\hline & 1892 & 1896 & 1900 & 5 & 4 & 9 \\
\hline & 1901 & 1911 & 1917 & 11 & 6 & 17 \\
\hline & 1918 & 1927 & 1972 & 10 & 45 & 55 \\
\hline \multirow{7}{*}{ Chile } & 1821 & 1822 & 1856 & 2 & 34 & 36 \\
\hline & 1857 & 1867 & 1870 & 11 & 3 & 14 \\
\hline & 1871 & 1874 & 1879 & 4 & 5 & 9 \\
\hline & 1880 & 1889 & 1891 & 10 & 2 & 12 \\
\hline & 1892 & 1896 & 1901 & 5 & 5 & 10 \\
\hline & 1902 & 1911 & 1919 & 10 & 8 & 18 \\
\hline & 1920 & 1929 & 1974 & 10 & 45 & 55 \\
\hline \multirow{3}{*}{ Colombia } & 1820 & 1824 & 1903 & 5 & 79 & 84 \\
\hline & 1904 & 1909 & 1914 & 6 & 5 & 11 \\
\hline & 1915 & 1928 & 1975 & 14 & 47 & 61 \\
\hline \multirow{4}{*}{ Mexico } & 1823 & 1825 & 1862 & 3 & 37 & 40 \\
\hline & 1863 & 1865 & 1877 & 3 & 12 & 15 \\
\hline & 1878 & 1890 & 1892 & 13 & 2 & 15 \\
\hline & 1893 & 1909 & 1972 & 17 & 63 & 80 \\
\hline \multirow{5}{*}{ Peru } & 1822 & 1825 & 1860 & 4 & 35 & 39 \\
\hline & 1861 & 1873 & 1884 & 13 & 11 & 24 \\
\hline & 1885 & 1891 & 1903 & 7 & 12 & 19 \\
\hline & 1904 & 1911 & 1918 & 8 & 7 & 15 \\
\hline & 1919 & 1928 & 1972 & 10 & 44 & 54 \\
\hline \multirow{4}{*}{ Uruguay } & 1863 & 1864 & 1869 & 2 & 5 & 7 \\
\hline & 1870 & 1873 & 1880 & 4 & 7 & 11 \\
\hline & 1881 & 1889 & 1894 & 9 & 5 & 14 \\
\hline & 1895 & 1906 & 1974 & 12 & 68 & 80 \\
\hline Average & \multicolumn{3}{|c|}{ All Cycles } & 8 & 22 & 30 \\
\hline
\end{tabular}


Table I

International Capital Flow Cycles: Duration

1970-2015

\begin{tabular}{|c|c|c|c|c|c|c|}
\hline \multirow{2}{*}{ Country } & \multicolumn{3}{|c|}{ Cycles } & \multicolumn{3}{|c|}{ Duration } \\
\hline & Beginning & Peak & End & Booms & Busts & Whole Cycle \\
\hline \multirow{2}{*}{ Argentina } & 1972 & 1981 & 1989 & 10 & 8 & 18 \\
\hline & 1990 & 1997 & 2015 & 8 & 18 & 26 \\
\hline \multirow{3}{*}{ Brazil } & 1972 & 1981 & 1990 & 10 & 9 & 19 \\
\hline & 1991 & 1997 & 2003 & 7 & 6 & 13 \\
\hline & 2004 & 2010 & 2015 & 7 & 5 & 12 \\
\hline \multirow{3}{*}{ Chile } & 1975 & 1981 & 1988 & 7 & 7 & 14 \\
\hline & 1989 & 1998 & 2007 & 10 & 9 & 19 \\
\hline & 2008 & 2013 & 2015 & 6 & 2 & 8 \\
\hline \multirow{3}{*}{ Colombia } & 1972 & 1981 & 1992 & 10 & 11 & 21 \\
\hline & 1993 & 1996 & 2003 & 4 & 7 & 11 \\
\hline & 2004 & 2012 & 2015 & 9 & 3 & 12 \\
\hline \multirow{3}{*}{ Mexico } & 1972 & 1981 & 1989 & 10 & 8 & 18 \\
\hline & 1990 & 1993 & 2007 & 4 & 14 & 18 \\
\hline & 2008 & 2013 & 2015 & 6 & 2 & 8 \\
\hline \multirow{4}{*}{ Peru } & 1972 & 1974 & 1977 & 3 & 3 & 6 \\
\hline & 1978 & 1982 & 1991 & 5 & 9 & 14 \\
\hline & 1992 & 1999 & 2001 & 8 & 2 & 10 \\
\hline & 2002 & 2014 & 2015 & 13 & 1 & 14 \\
\hline \multirow{4}{*}{ Uruguay } & 1974 & 1981 & 1989 & 8 & 8 & 16 \\
\hline & 1990 & 2000 & 2003 & 11 & 3 & 14 \\
\hline & 2004 & 2006 & 2009 & 3 & 3 & 6 \\
\hline & 2010 & 2015 & & 6 & & \\
\hline Average & \multicolumn{3}{|c|}{ All Cycles } & 8 & 7 & 14 \\
\hline
\end{tabular}

Notes: The database on issuance ends in 2015, thus the duration of the bust of the last cycle for Argentina, Brazil, Chile, Colombia, Mexico, and Peru may be truncated. For Uruguay, the duration of the bonanza of the last cycle may be truncated. The average duration of the busts (cycles) when only complete cycles are included is 8 (15) years. 
Table II

International Borrowing Cycles: Amplitude

1820-1931

\begin{tabular}{|c|c|c|c|c|c|}
\hline \multirow{2}{*}{ Country } & \multicolumn{3}{|c|}{ Cycles } & \multicolumn{2}{|c|}{ Amplitude } \\
\hline & Beginning & Peak & End & Bonanzas & Busts \\
\hline \multirow{5}{*}{ Argentina } & 1823 & 1824 & 1859 & 1.69 & -0.01 \\
\hline & 1860 & 1872 & 1877 & 1.97 & 0.35 \\
\hline & 1878 & 1888 & 1893 & 4.79 & 1.60 \\
\hline & 1894 & 1910 & 1919 & 2.29 & 0.57 \\
\hline & 1920 & 1927 & 1972 & 0.24 & 0.09 \\
\hline \multirow{6}{*}{ Brazil } & 1823 & 1825 & 1856 & 0.90 & 0.08 \\
\hline & 1857 & 1864 & 1869 & 0.54 & 0.47 \\
\hline & 1870 & 1887 & 1891 & 1.75 & 0.56 \\
\hline & 1892 & 1896 & 1900 & 0.35 & 0.49 \\
\hline & 1901 & 1911 & 1917 & 2.56 & 0.66 \\
\hline & 1918 & 1927 & 1972 & 0.93 & 0.38 \\
\hline \multirow{7}{*}{ Chile } & 1821 & 1822 & 1856 & 1.56 & -0.04 \\
\hline & 1857 & 1867 & 1870 & 0.84 & 0.09 \\
\hline & 1871 & 1874 & 1879 & 0.22 & 0.00 \\
\hline & 1880 & 1889 & 1891 & 1.41 & 0.00 \\
\hline & 1892 & 1896 & 1901 & 1.00 & 0.13 \\
\hline & 1902 & 1911 & 1919 & 0.98 & 0.27 \\
\hline & 1920 & 1929 & 1974 & 1.91 & 0.28 \\
\hline \multirow{3}{*}{ Colombia } & 1820 & 1824 & 1903 & 6.88 & 0.88 \\
\hline & 1904 & 1909 & 1914 & 0.47 & 0.03 \\
\hline & 1915 & 1928 & 1975 & 2.29 & -0.09 \\
\hline \multirow{4}{*}{ Mexico } & 1823 & 1825 & 1862 & 4.30 & 0.00 \\
\hline & 1863 & 1865 & 1877 & 3.08 & 0.37 \\
\hline & 1878 & 1890 & 1892 & 3.97 & 0.44 \\
\hline & 1893 & 1909 & 1972 & 4.66 & 0.76 \\
\hline \multirow{5}{*}{ Peru } & 1822 & 1825 & 1860 & 3.39 & -0.09 \\
\hline & 1861 & 1873 & 1884 & 3.46 & -0.58 \\
\hline & 1885 & 1891 & 1903 & 0.58 & -0.29 \\
\hline & 1904 & 1911 & 1918 & 0.78 & -0.06 \\
\hline & 1919 & 1928 & 1972 & 0.94 & -0.08 \\
\hline \multirow{4}{*}{ Uruguay } & 1863 & 1864 & 1869 & 0.51 & 0.11 \\
\hline & 1870 & 1873 & 1880 & 2.30 & 0.16 \\
\hline & 1881 & 1889 & 1894 & 1.91 & 0.28 \\
\hline & 1895 & 1906 & 1974 & 0.37 & 0.61 \\
\hline Average & & All Cycles & & 1.94 & 0.25 \\
\hline
\end{tabular}

Notes: Bonanzas capture the accumulated net issuance over the boom as a share of exports in the year of the peak of the cycle. Busts capture the accumulated net issuance over the bust as share of exports in the year of the trough of the cycle. 
Table II

International Borrowing Cycles: Amplitude

1970-2015

\begin{tabular}{|c|c|c|c|c|c|}
\hline \multirow{2}{*}{ Country } & \multicolumn{3}{|c|}{ Cycles } & \multicolumn{2}{|c|}{ Amplitude } \\
\hline & Beginning & Peak & End & Bonanzas & Busts \\
\hline \multirow{2}{*}{ Argentina } & 1972 & 1981 & 1989 & 1.31 & 0.92 \\
\hline & 1990 & 1997 & 2015 & 3.19 & 0.21 \\
\hline \multirow{3}{*}{ Brazil } & 1972 & 1981 & 1990 & 1.34 & 0.70 \\
\hline & 1991 & 1997 & 2003 & 1.36 & 0.17 \\
\hline & 2004 & 2010 & 2015 & 1.21 & 0.88 \\
\hline \multirow{3}{*}{ Chile } & 1975 & 1981 & 1988 & 1.43 & 0.83 \\
\hline & 1989 & 1998 & 2007 & 1.26 & 0.12 \\
\hline & 2008 & 2013 & 2015 & 0.80 & 0.26 \\
\hline \multirow{3}{*}{ Colombia } & 1972 & 1981 & 1992 & 0.88 & 0.94 \\
\hline & 1993 & 1996 & 2003 & 1.05 & 0.02 \\
\hline & 2004 & 2012 & 2015 & 0.78 & 0.60 \\
\hline \multirow{3}{*}{ Mexico } & 1972 & 1981 & 1989 & 1.98 & 0.86 \\
\hline & 1990 & 1993 & 2007 & 1.09 & 0.19 \\
\hline & 2008 & 2013 & 2015 & 0.40 & 0.16 \\
\hline \multirow{4}{*}{ Peru } & 1972 & 1974 & 1977 & 0.67 & 0.21 \\
\hline & 1978 & 1982 & 1991 & 0.41 & 0.07 \\
\hline & 1992 & 1999 & 2001 & 0.59 & -0.01 \\
\hline & 2002 & 2014 & 2015 & 1.36 & 0.12 \\
\hline \multirow{4}{*}{ Uruguay } & 1974 & 1981 & 1989 & 0.66 & 0.35 \\
\hline & 1990 & 2000 & 2003 & 1.31 & 0.21 \\
\hline & 2004 & 2006 & 2009 & 0.87 & 0.25 \\
\hline & 2010 & 2015 & & 0.93 & \\
\hline Average & & All Cycles & & 1.13 & 0.38 \\
\hline
\end{tabular}

Notes: Bonanzas capture the accumulated net issuance over the boom as a share of exports in the year of the peak of the cycle. Busts capture the accumulated net issuance over the bust as share of exports in the year of the trough of the cycle. The database on issuance ends in 2015, thus the bust of the last cycle for Argentina, Brazil, Chile, Colombia, Mexico, and Peru may be truncated. The average amplitude of the busts when only complete cycles are included is also 0.38 . 
Table III

Monetary Policy in the Financial Center: Then and Now

Is Monetary Policy more Volatile during Crises in the Financial Center?

\begin{tabular}{|l|cc|cc|}
\hline \multirow{2}{*}{ Volatility } & \multicolumn{2}{|c|}{$1820-1931$} & \multicolumn{2}{c|}{$1970-2015$} \\
\cline { 2 - 5 } & All Sample & Crises & All Sample & Crises \\
\hline Standard Deviation & 1.06 & 0.94 & 3.79 & 4.73 \\
Coefficient of Variation & 0.27 & 0.26 & 0.69 & 0.83 \\
\hline
\end{tabular}

Notes: The Standard Deviation and the Coefficient of Variation are estimated using interest rates at annual frequencies. Crisis episodes are defined as the year of the crisis in the financial center and the 10-year episode around the crisis. The years of the beginning of the crises in the financial center are $1825,1873,1890$, and 1929 for the first episode of financial globalization and 1981 and 2007 for the second episode of financial globalization. The interest rate for the first episode of financial globalization is the U.K. bank rate and the interest rate for the second episode of financial globalization is the U.S. federal funds rate.

Are Tightenings and Easings more Prolonged and Extreme during Crises in the Financial Center?

\begin{tabular}{|c|c|c|c|c|c|c|}
\hline \multirow{3}{*}{ Episodes } & \multicolumn{4}{|c|}{ Average Interest Rate Changes } & \multirow{2}{*}{\multicolumn{2}{|c|}{$\begin{array}{c}\text { P-Values } \\
\text { Crises versus all Sample }\end{array}$}} \\
\hline & \multicolumn{2}{|c|}{ Crises } & \multicolumn{2}{|c|}{ All Sample } & & \\
\hline & Before & After & Tightening & Easing & Tightening & Easing \\
\hline $1820-1931$ & 6.97 & -4.10 & 6.95 & -4.53 & 0.99 & 0.55 \\
\hline $1970-2015$ & 31.71 & -22.07 & 11.73 & -12.68 & 0.00 & 0.00 \\
\hline
\end{tabular}

Notes: The first two columns in this table show the average percent changes in the nominal interest rate for a 5-year episode before (after) the year of the beginnng of a crisis in the financial center. The years of the beginning of the crises in the financial center are 1825, 1873, 1890, and 1929 for the first episode of financial globalization and 1981 and 2007 for the second episode of financial globalization. The next two columns show the average 5 -year changes in the interest rate over all the sample. I separate the episodes into Tightenings (Easings) according to whether the 5-year averages are positive or negative. The last two columns report the $p$-values of comparing Tightenings (Easings) during crises to Tightenings (Easings) over all the sample. The interest rate for the first episode of financial globalization is the U.K. bank rate and the interest rate for the second episode of financial globalization is the U.S. federal funds rate. Since by construction these series are serially correlated and they are also heteroscedastic, the t-statistics and $p$-values have to be made robust to serial correlation and heteroskedasticity using HAC standard errors. 
Table IV

Can Monetary Policy in the Financial Center Explain the Time-Varying Characteristics of Bonanzas and Busts?

\begin{tabular}{|c|c|c|c|c|c|}
\hline \multirow{2}{*}{ Explanatory Variables } & \multicolumn{5}{|c|}{ Bonanzas } \\
\hline & (1) & (2) & (3) & (4) & (5) \\
\hline Growth Financial Center Interest Rate & $\begin{array}{c}0.00 \\
(0.47)\end{array}$ & & & & \\
\hline Growth Financial Center Interest Rate*First Episode & & $\begin{array}{c}0.01 \\
(0.60)\end{array}$ & $\begin{array}{c}0.01 \\
(0.64)\end{array}$ & $\begin{array}{c}0.01 \\
(0.58)\end{array}$ & $\begin{array}{c}0.02 \\
(0.58)\end{array}$ \\
\hline Growth Financial Center Interest Rate*Second Episode*Systemic Cycle & & $\begin{array}{c}-0.01 \\
(0.05)\end{array}$ & $\begin{array}{c}-0.01 \\
(0.04)\end{array}$ & $\begin{array}{c}-0.01 \\
(0.06)\end{array}$ & $\begin{array}{c}-0.01 \\
(0.10)\end{array}$ \\
\hline Growth Financial Center Interest Rate*Second Episode*Idiosyncratic Cycle & & $\begin{array}{c}0.00 \\
(0.99)\end{array}$ & $\begin{array}{c}0.00 \\
(0.89)\end{array}$ & $\begin{array}{c}0.01 \\
(0.93)\end{array}$ & $\begin{array}{c}0.01 \\
(0.79)\end{array}$ \\
\hline Exports Growth & & & $\begin{array}{c}0.09 \\
(0.01)\end{array}$ & & \\
\hline Terms of Trade Growth & & & & $\begin{array}{c}-0.02 \\
(0.54)\end{array}$ & \\
\hline World Imports Growth & & & & & $\begin{array}{c}-0.03 \\
(0.68)\end{array}$ \\
\hline Number of Observations & 56 & 56 & 56 & 56 & 56 \\
\hline R-Squared & 0.00 & 0.02 & 0.11 & 0.02 & 0.02 \\
\hline
\end{tabular}

\begin{tabular}{|c|c|c|c|c|c|}
\hline \multirow{2}{*}{ Explanatory Variables } & \multicolumn{5}{|c|}{ Busts } \\
\hline & (1) & $(2)$ & (3) & $(4)$ & (5) \\
\hline Growth Financial Center Interest Rate & $\begin{array}{c}0.00 \\
(0.88)\end{array}$ & & & & \\
\hline Growth Financial Center Interest Rate*First Episode & & $\begin{array}{c}0.01 \\
(0.18)\end{array}$ & $\begin{array}{c}0.01 \\
(0.13)\end{array}$ & $\begin{array}{c}0.01 \\
(0.17)\end{array}$ & $\begin{array}{c}0.01 \\
(0.22)\end{array}$ \\
\hline Growth Financial Center Interest Rate*Second Episode*Systemic Cycle & & $\begin{array}{c}-0.02 \\
(0.03)\end{array}$ & $\begin{array}{c}-0.02 \\
(0.03)\end{array}$ & $\begin{array}{c}-0.02 \\
(0.04)\end{array}$ & $\begin{array}{c}-0.02 \\
(0.03)\end{array}$ \\
\hline Growth Financial Center Interest Rate*Second Episode*Idiosyncratic Cycle & & $\begin{array}{c}0.01 \\
(0.63)\end{array}$ & $\begin{array}{c}0.00 \\
(0.61)\end{array}$ & $\begin{array}{c}0.00 \\
(0.70)\end{array}$ & $\begin{array}{c}0.01 \\
(0.61)\end{array}$ \\
\hline Exports Growth & & & $\begin{array}{c}-0.01 \\
(0.32)\end{array}$ & & \\
\hline Terms of Trade Growth & & & & $\begin{array}{c}-0.01 \\
(0.24)\end{array}$ & \\
\hline World Imports Growth & & & & & $\begin{array}{c}0.01 \\
(0.80)\end{array}$ \\
\hline Number of Observations & 55 & 55 & 55 & 55 & 55 \\
\hline R-Squared & 0.00 & 0.14 & 0.15 & 0.16 & 0.14 \\
\hline
\end{tabular}

Notes: The dependent variable of the regression in the top panel (bonanza) is the accumulated issuance as a share of exports during capital flow booms. The dependent variable of the regression in the bottom panel (bust) is the accumulated issuance as a share of exports during capital flow crashes. The Growth Financial Center Interest Rate is the 3-year average percent change of the U.K. bank interest rate for the first episode of financial globalization and of the U.S. federal funds interest rate for the second episode of financial globalization. Export Growth, Terms of Trade Growth, and World Imports Growth are the 3-year average growth rates of the trend of (real) exports, the terms- of-trade, and (real) world imports, respectively. For the top panel, the 3-year average of the explanatory variables include the year of the peak of the cycle and the two prior years. For the bottom panel, the 3-year average of the explanatory variables include the year of the beginning the capital flow crash and the following 2 years. First Episode (Second Episode) is a dummy variable equal to one during the first episode (second episode) of financial globalization and zero otherwise. Systemic Cycle (Idiosyncratic Cycle) is a dummy equal to one for Systemic (Idiosyncratic) Cycles and zero otherwise. P-values are in parentheses below the coefficients. P-values are estimated with White heteroskedasticy-corrected standard errors when necessary. 
Figure I

Prospectuses

\section{BUENOS AYRES 6\% STATE LOAN, 1870,}

Cinder the authority of the State Lenos of the $\frac{17}{15}$ November, 18e8, and $\frac{27}{28}$ Jammary, 1870;

$\frac{18}{10}$ of Felmary, 1869 (as varied by a further Lac of $\frac{3}{4}$ September, 1869), and $\frac{28}{28}$ January, 1870 ,

$$
\text { FOR £I,O34,700 STERLING, }
$$

In Bonds to Bearer for $£ 100, £ 500$, and $£ 1,000$ each,

The Interest Payable Half-Yearly in London.

The Loan to be redeemed at par by Annual Drawings in about 33 years, by means of an accumulative Sinking Fund, which however the Government reserves to itself the right to increase, so as to redeem the Loan at an earlier period.

PRICE OF ISSUE, 88 PER CENT.

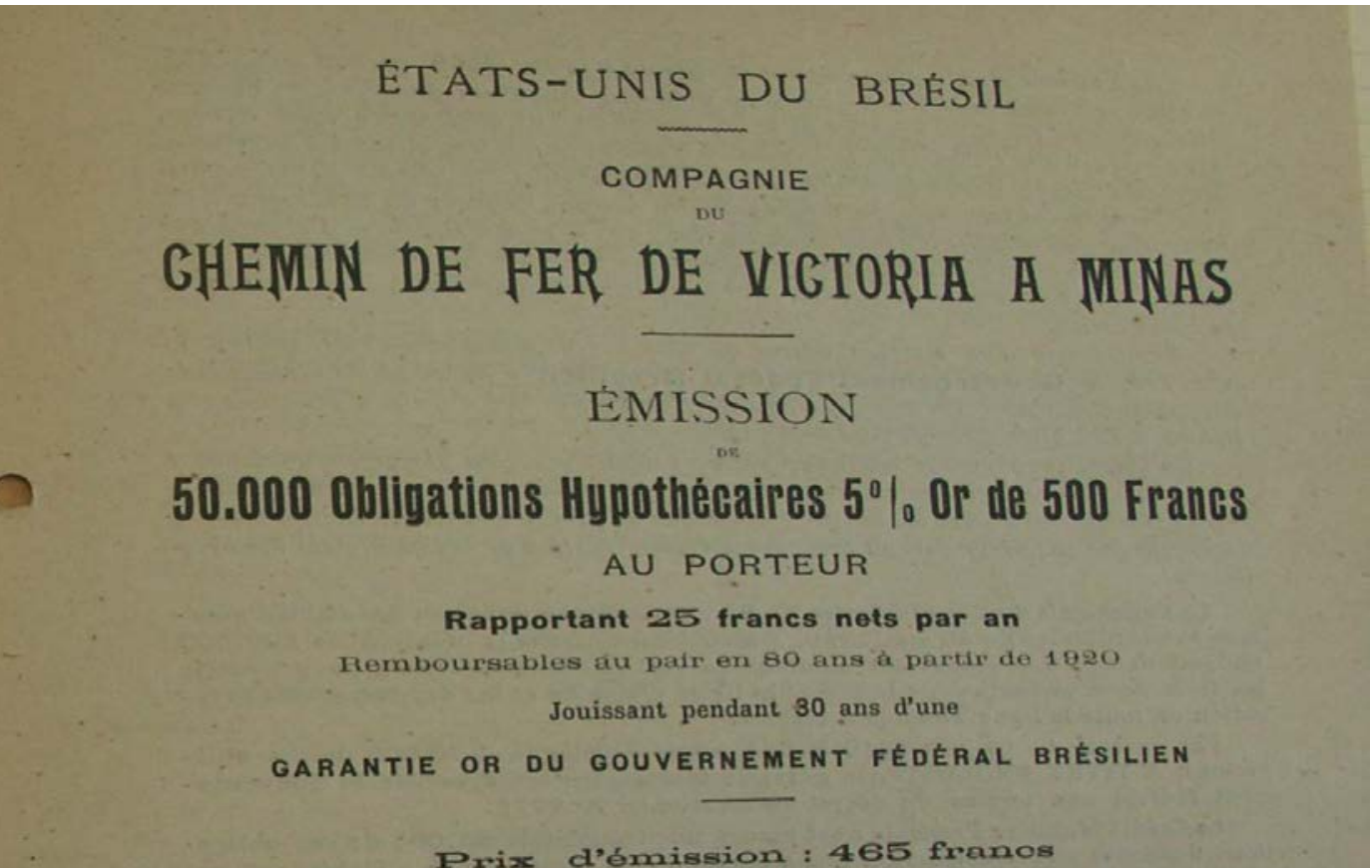




\section{Figure I}

\section{Conversion and Redemption Bond Prospectus}

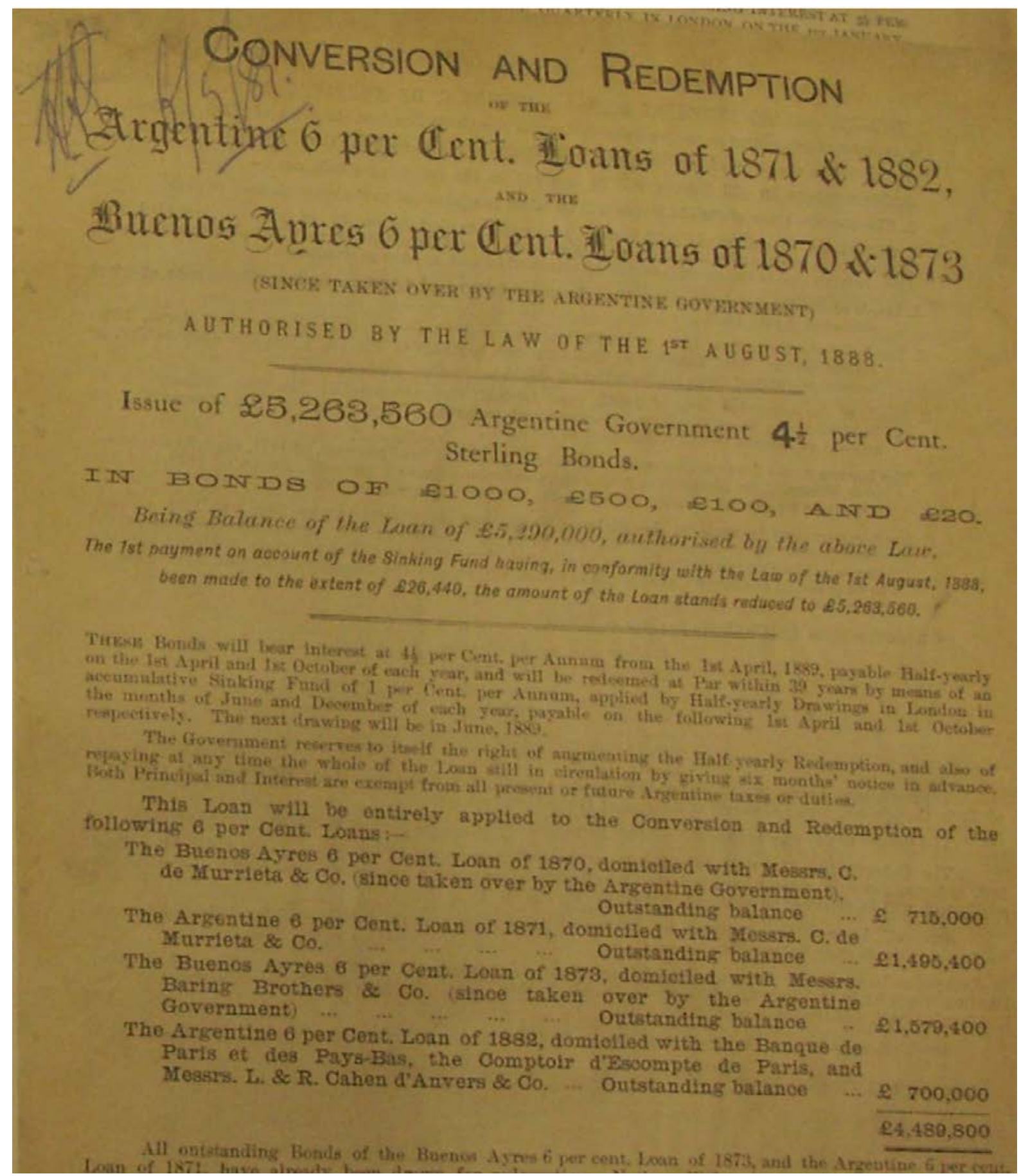


Figure II

Latin America Total International Issuance (Million British Pounds)

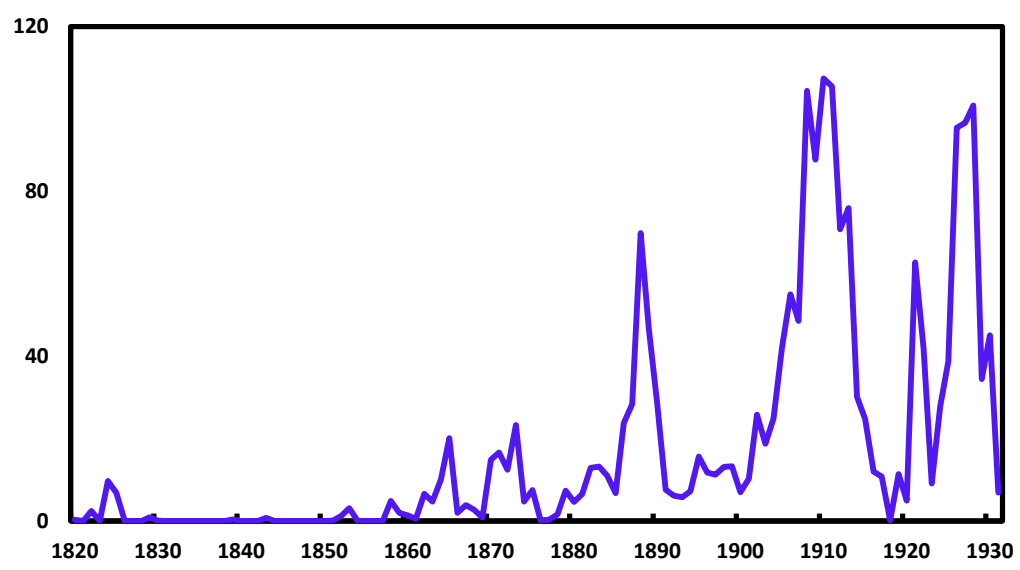

Latin America Public and Private International Issuance

(Million British pounds)

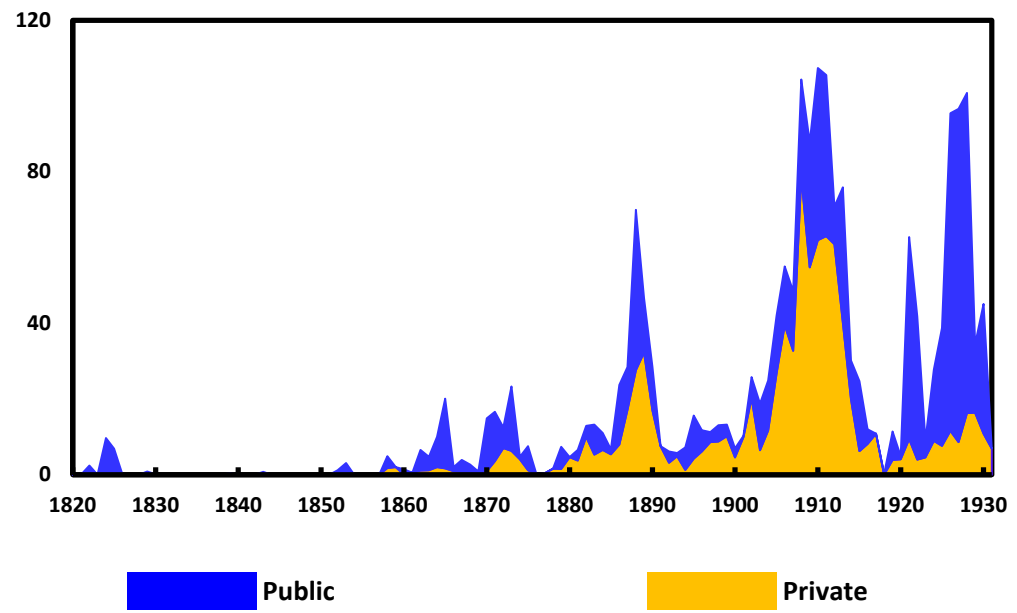

Latin America Total International Issuance (Share of Exports)

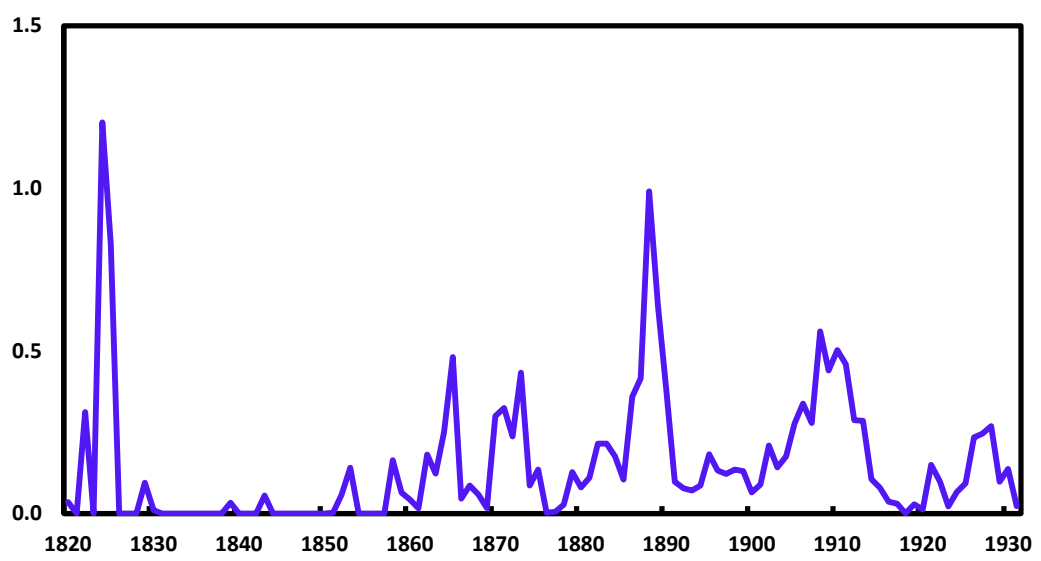

Notes: International Issuance is Gross Primary International Issuance 
Figure II

1970-2015

Latin America International Issuance

(Billion US Dollars)

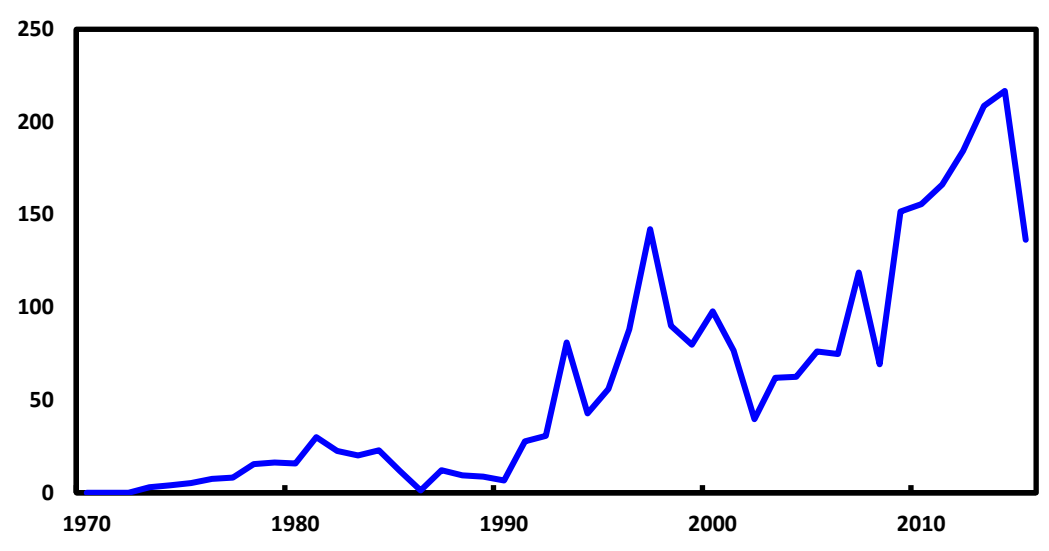

Latin America International Issuance: Public and Private (Billion US Dollars)

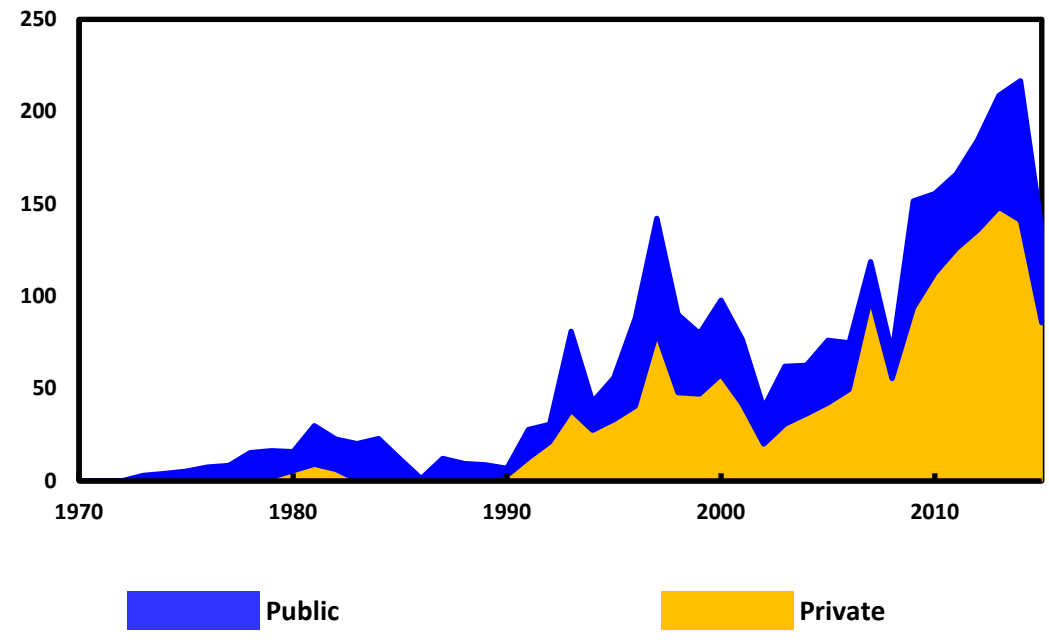

Latin America International Issuance

(Share of Exports)

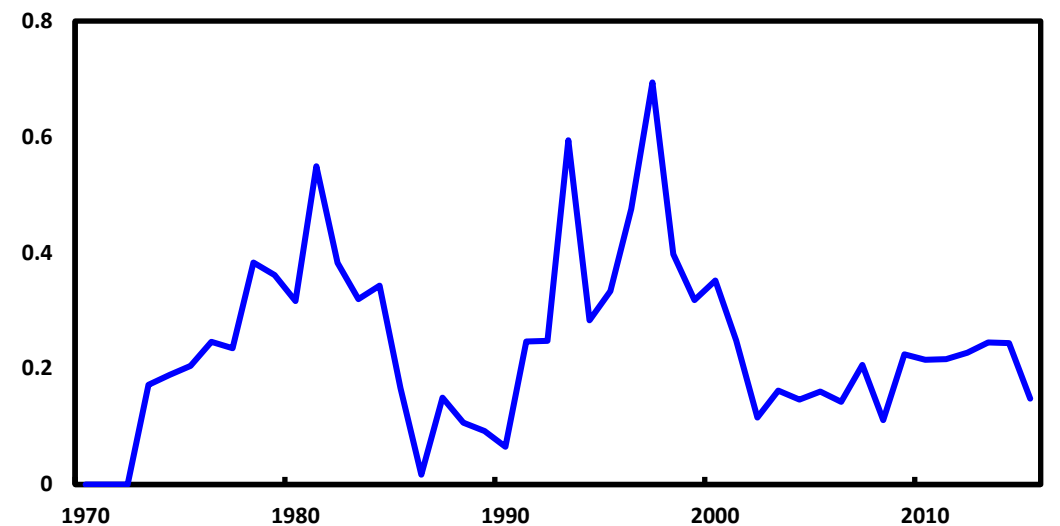

Notes: International Issuance is Gross Primary International Issuance 
Figure III

International Issuance/Exports

Argentina
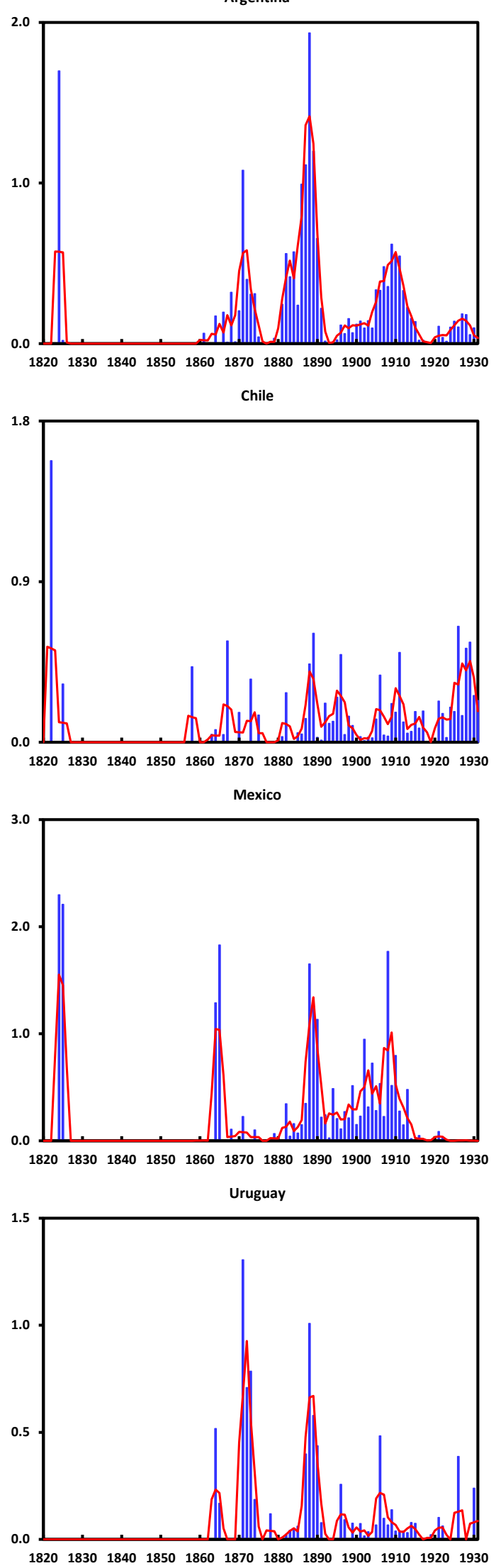

1820-1931
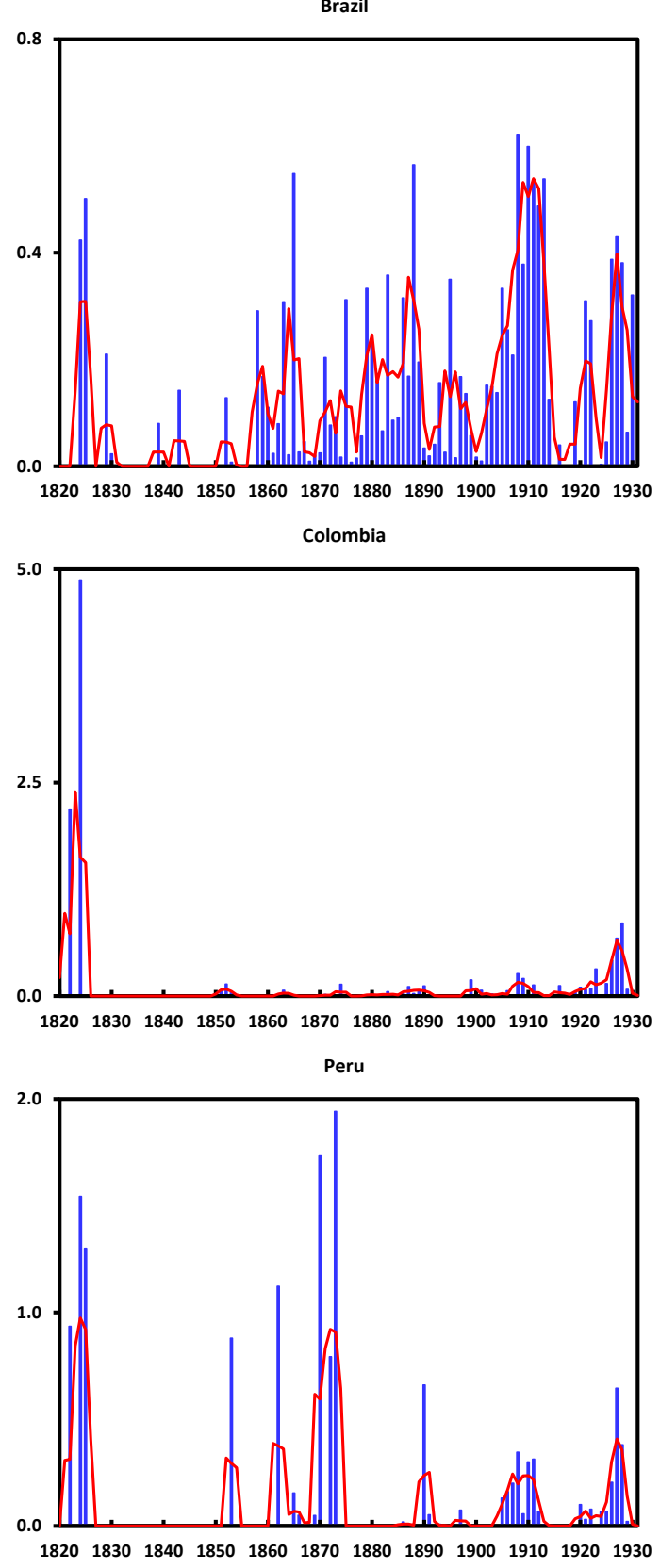

Notes:

Gross Primary International Issuance/Exports

Gross Primary International Issuance 3-Year Moving Average/Exports 
Figure III

International Issuance/Exports

Argentina
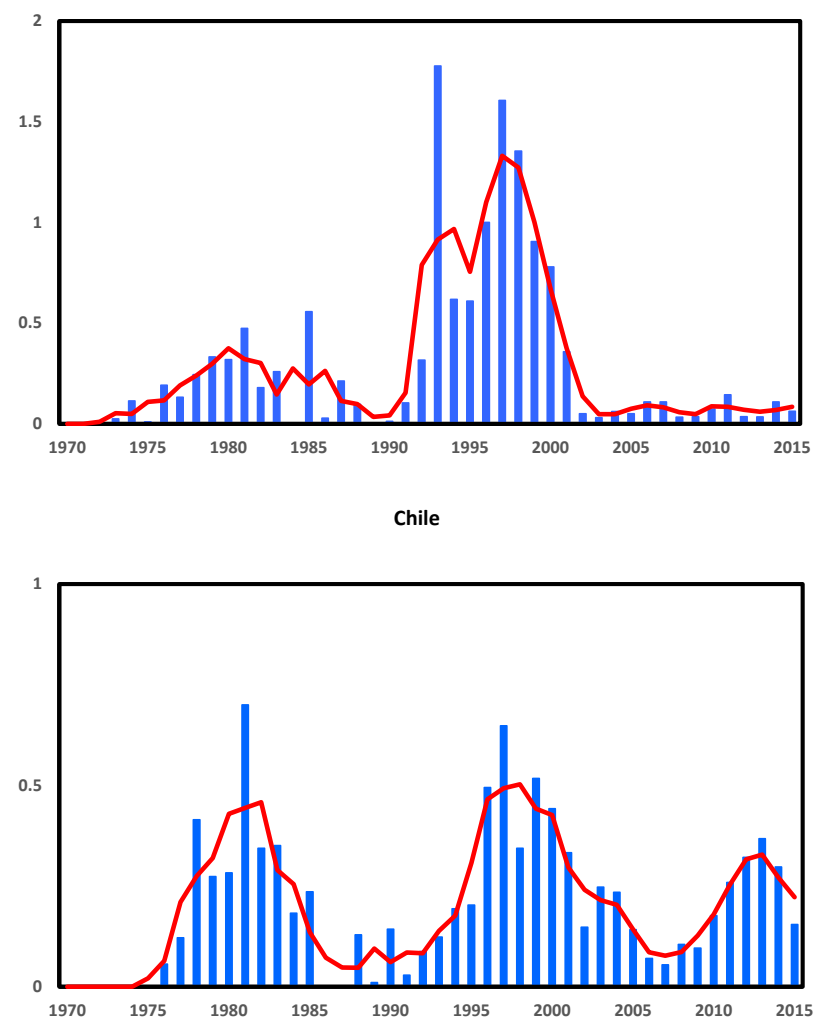

Mexico

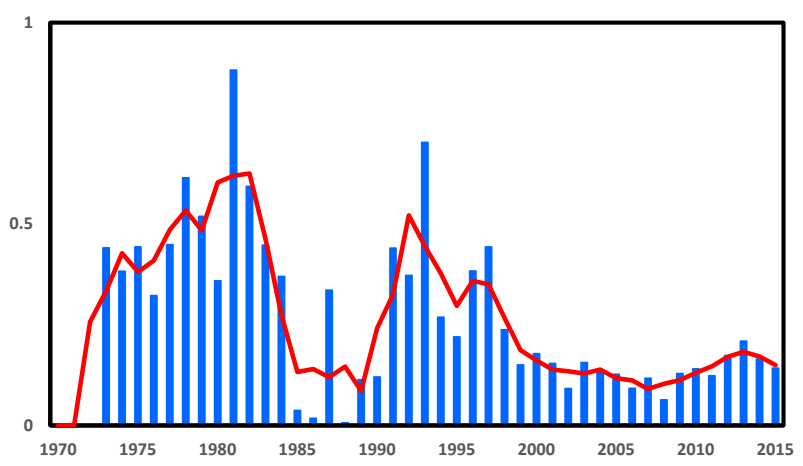

Uruguay

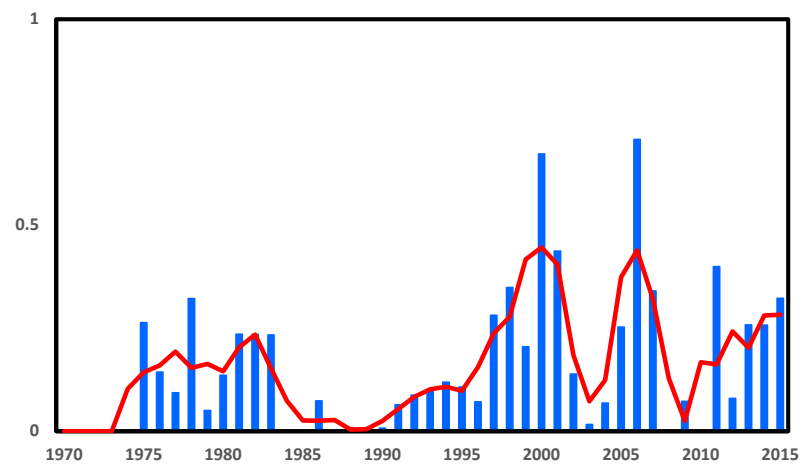

Brazil
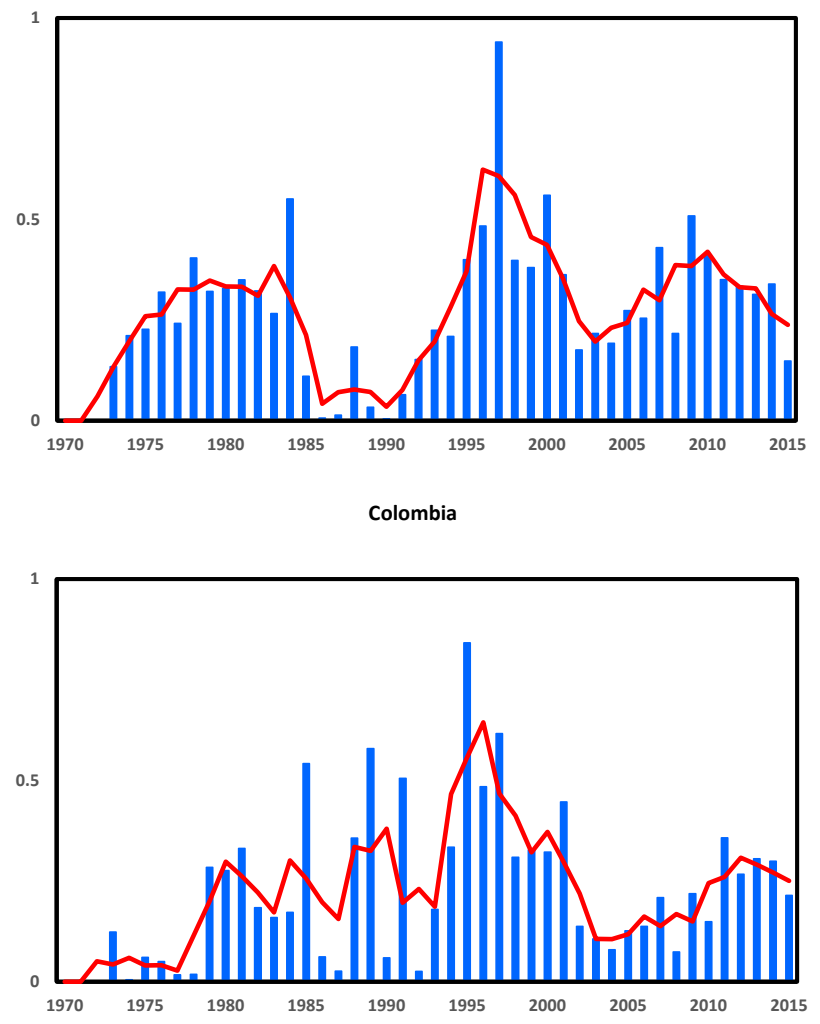

Peru

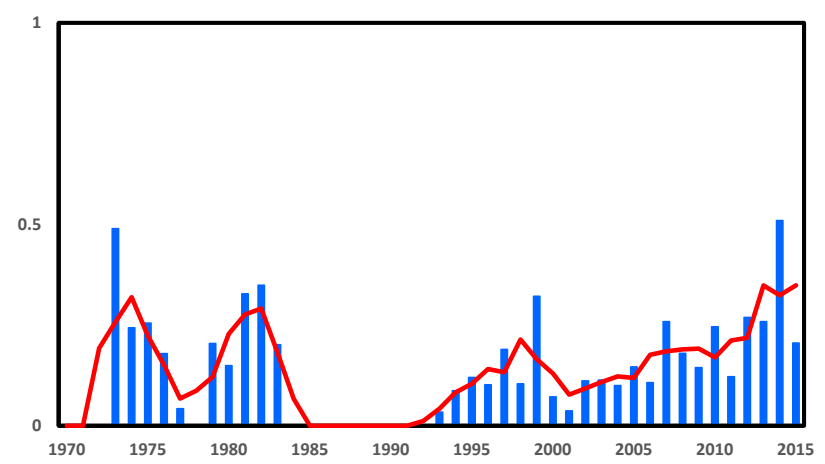

Notes:

Gross Primary International Issuance/Exports

Gross Primary International Issuance 3-Year Moving Average/Exports 
Figure IV

Are International Borrowing Cycles Changing?

Capital Flow Bonanzas: Then and Now

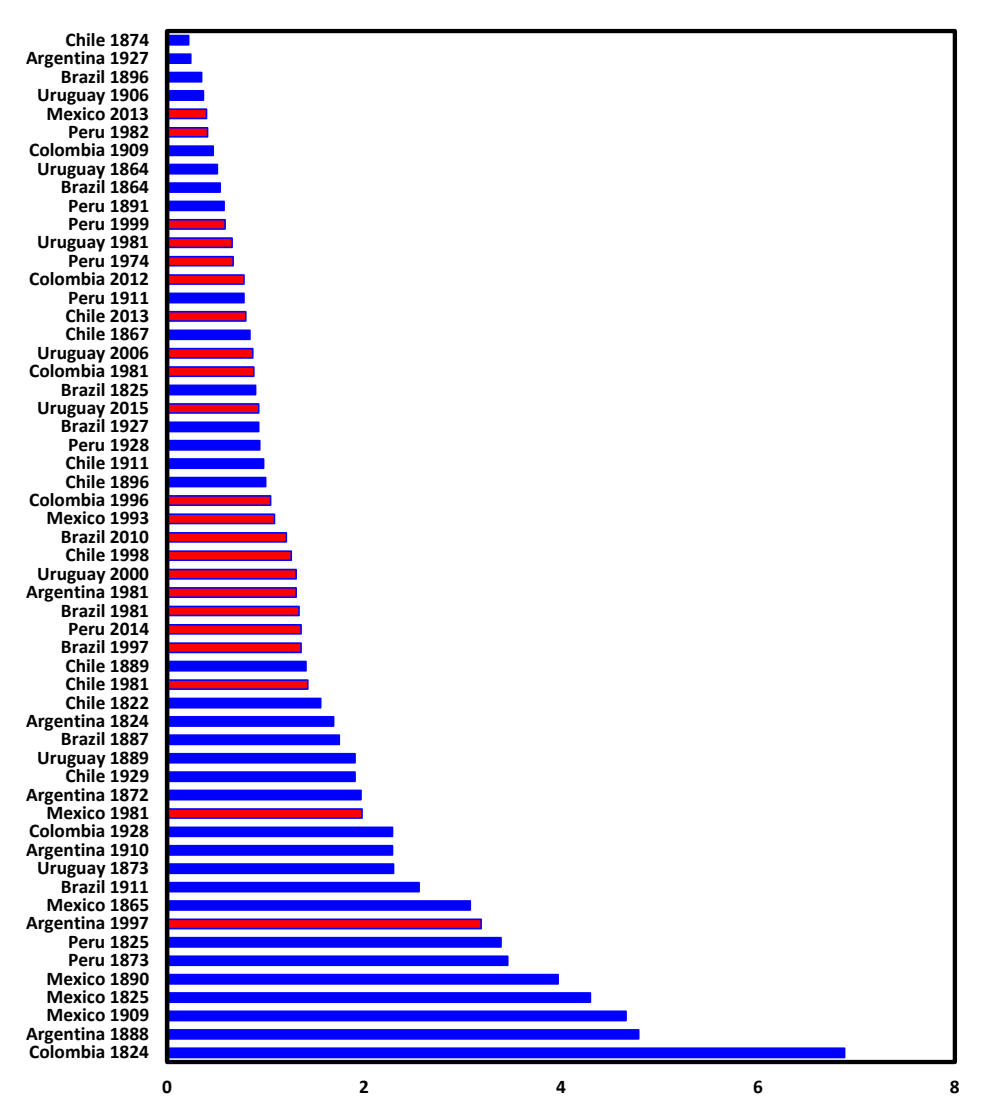

Capital Flow Busts: Then and Now

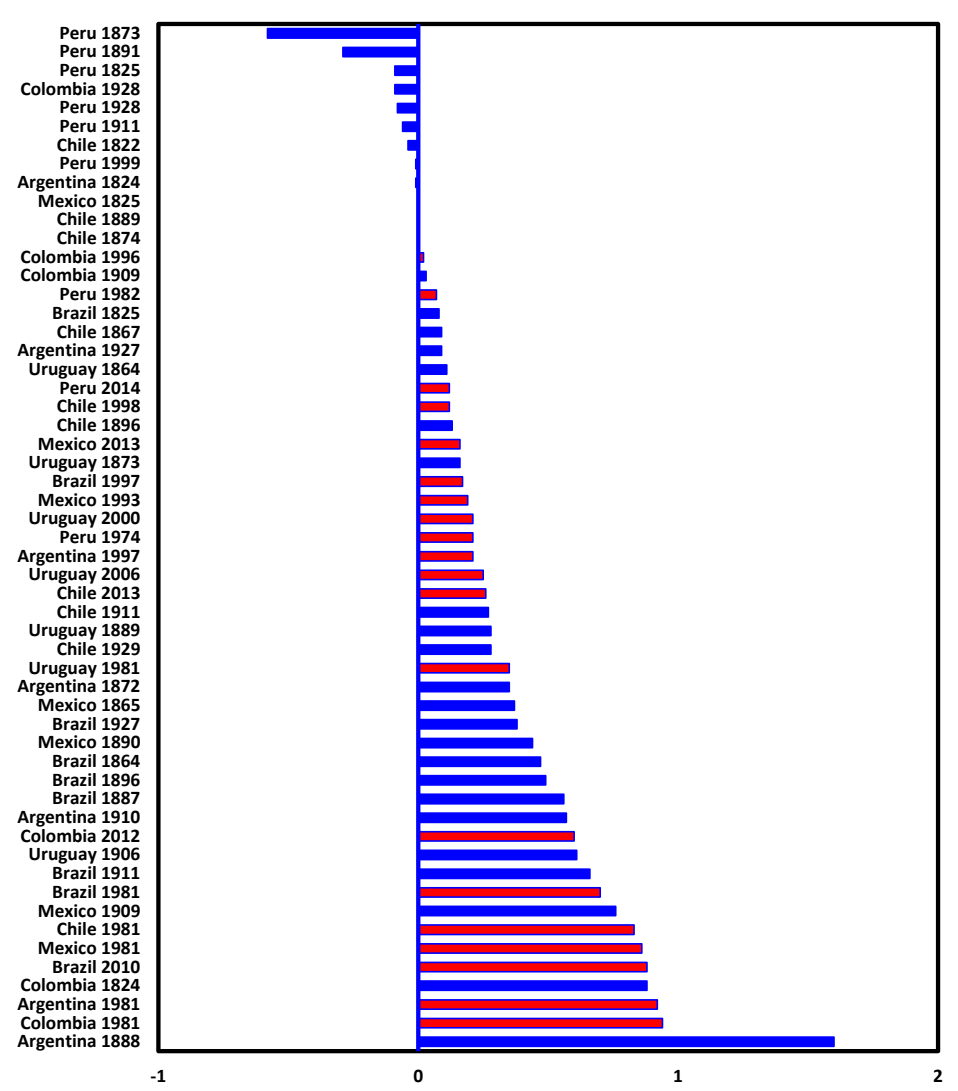
Capital flow bonanzas (busts) during the first episode of financial globalization
Capital flow bonanzas (busts) during the second episode of financial globalization

\begin{tabular}{|l|c|c|}
\hline \multirow{2}{*}{ Episodes } & \multicolumn{2}{c|}{ Amplitude } \\
\cline { 2 - 3 } & Bonanzas & Busts \\
\hline $\mathbf{1 8 2 0 - 1 9 3 1}$ & 1.94 & 0.25 \\
$\mathbf{1 9 7 0 - 2 0 1 5}$ & 1.13 & 0.38 \\
\hline P-Value & 0.01 & 0.09 \\
\hline
\end{tabular}

Notes: The amplitude of capital flow bonanzas (busts) captures the accumulated net issuance over the boom (bust) as a share of exports in the year of the peak (trough) of the cycle The amplitude of the capital flow bonanza (bust) as a share of exports is shown on the horizontal axis. Each capital flow bonanza (bust) is identified on the vertical axis with the name of the country and the year of the peak of the capital flow cycle. The bottom table shows the average amplitude of capital flow bonanzas (busts) in the two episodes of financial globalization. The test statistics in this table shows the one-tailed p-value at which the Null Hypothesis of equality of capital flow bonanzas (busts) in both episodes of financial globalization can be rejected. 
Figure $\mathbf{V}$

Are Systemic and Idiosyncratic International Borrowing Cycles Different?

Capital Flow Bonanzas: Systemic and Idiosyncratic

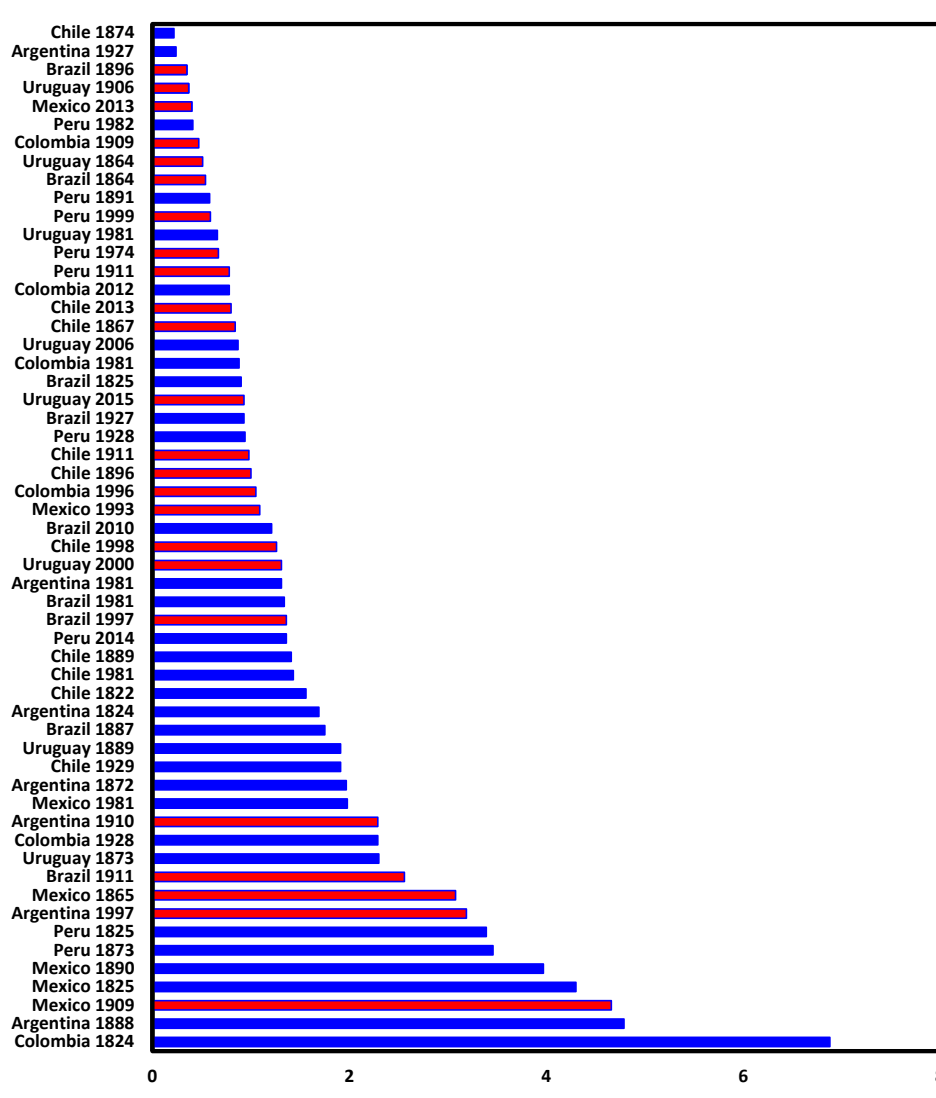

Capital Flow Busts: Systemic and Idiosyncratic

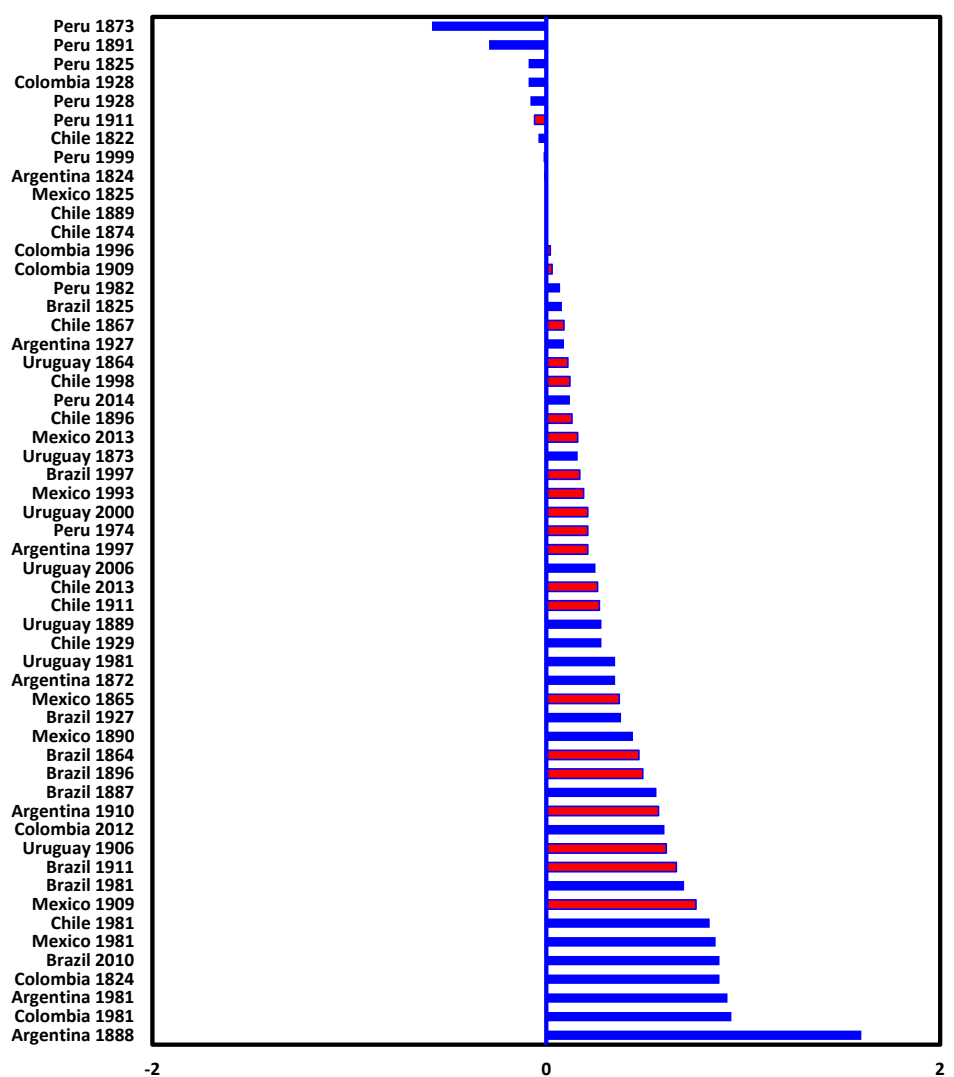

Systemic capital flow bonanzas (busts)

Idiosyncratic capital flow bonanzas (busts)

\begin{tabular}{|l|c|c|}
\hline \multirow{2}{*}{ Varieties } & \multicolumn{2}{c|}{ Amplitude } \\
\cline { 2 - 3 } & Bonanzas & Busts \\
\hline Systemic & 1.86 & 0.33 \\
Idiosyncratic & 1.30 & 0.26 \\
\hline P-Value & 0.05 & 0.25 \\
\hline
\end{tabular}

Notes: The amplitude of capital flow bonanzas (busts) captures the accumulated net issuance over the boom (bust) as a share of exports in the year of the peak (trough) of the cycle The amplitude of the capita flow bonanza (bust) as a share of exports is shown on the horizontal axis. Each capital flow bonanza (bust) is identified on the vertical axis with the name of the country and the year of the peak of the capital flow cycle. The bottom table shows the average amplitude of capital flow bonanzas (busts) during systemic and idiosyncratic capital flow cycles. The test statistics in this table shows the one-tailed p-value at which the Null Hypothesis of equality of capital flow bonanzas (busts) during systemic and idiosyncratic capital flow cycles can be rejected. 
Figure VI

Are Systemic and Idiosyncratic International Borrowing Cycles Changing?
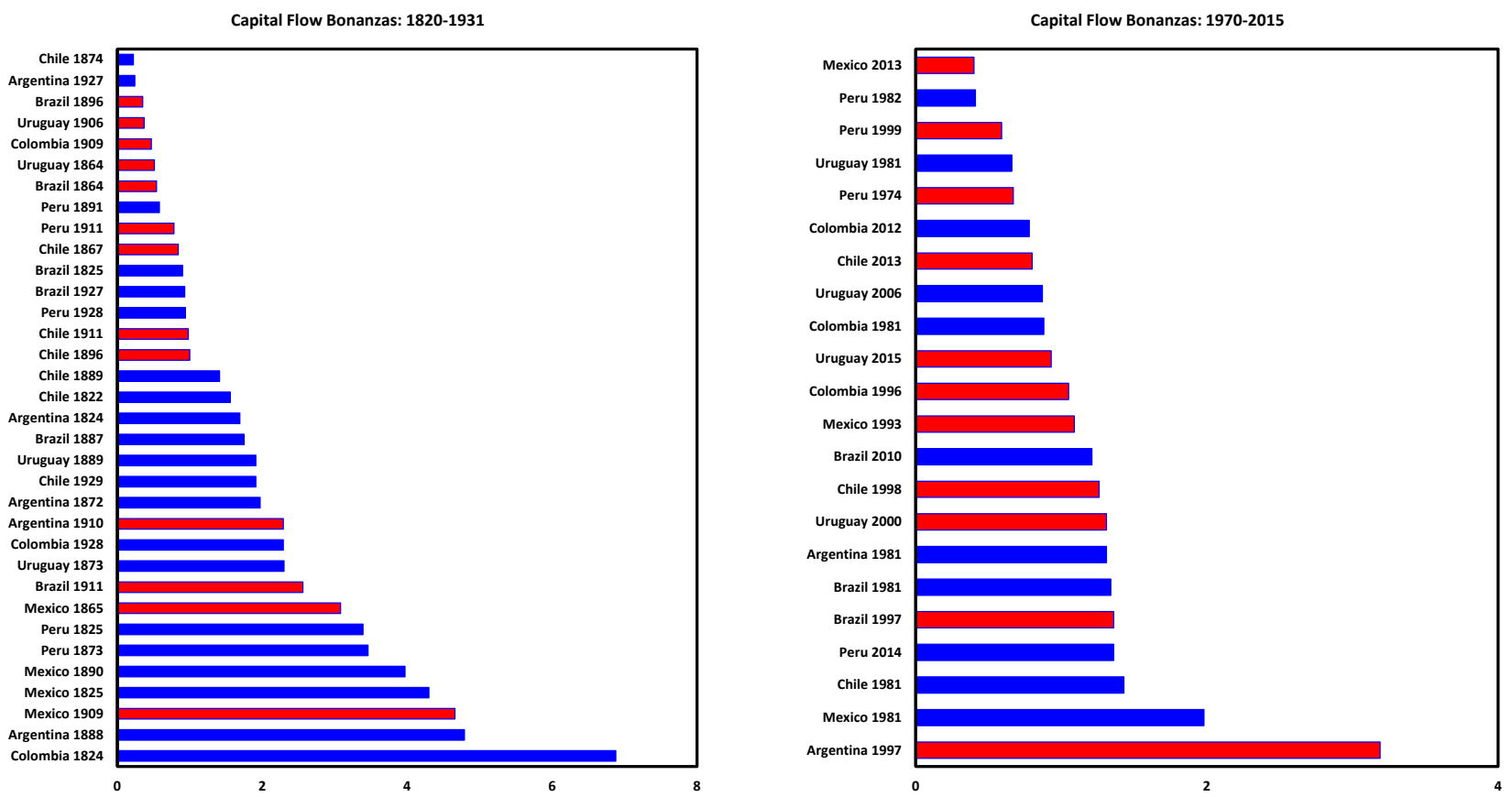

Capital Flow Busts: 1820-1931
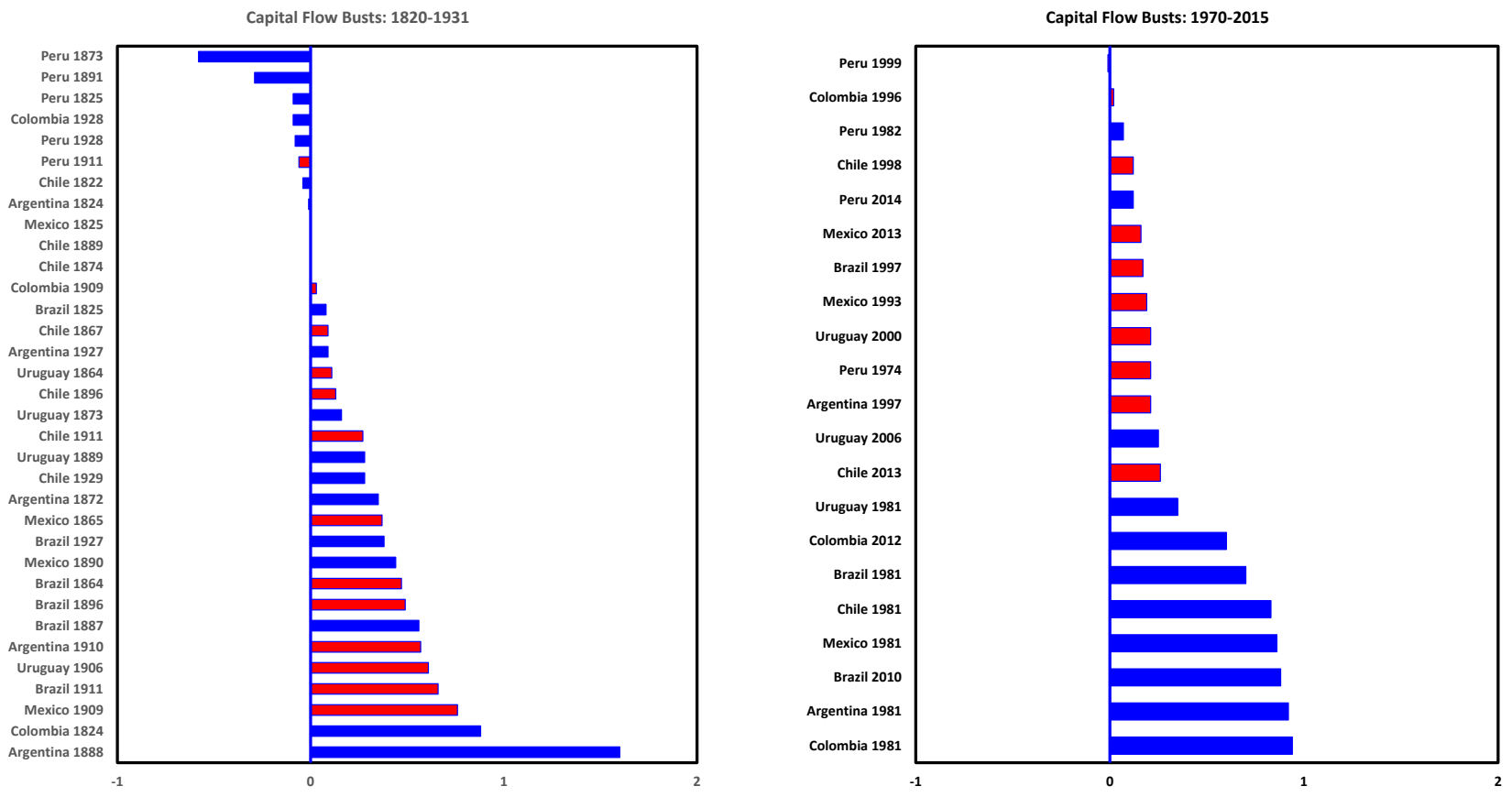

Systemic capital flow bonanzas (busts)
Idiosyncratic capital flow bonanzas (busts)
\begin{tabular}{|l|c|c|c|c|}
\hline \multirow{3}{*}{ Varieties } & \multicolumn{4}{c|}{ Amplitude } \\
\cline { 2 - 5 } & \multicolumn{2}{|c|}{$\mathbf{1 8 2 0 - 1 9 3 1}$} & \multicolumn{1}{|c|}{$\mathbf{9 7 0 - 2 0 1 5}$} \\
\cline { 2 - 5 } & Bonanzas & Busts & Bonanzas & Busts \\
\hline Systemic & 2.26 & 0.19 & 1.11 & 0.59 \\
Idiosyncratic & 1.42 & 0.35 & 1.15 & 0.15 \\
\hline P-value & $\mathbf{0 . 0 6}$ & $\mathbf{0 . 1 0}$ & $\mathbf{0 . 4 4}$ & $\mathbf{0 . 0 0}$ \\
\hline
\end{tabular}

Notes: The amplitude of capital flow bonanzas (busts) captures the accumulated net issuance over the boom (bust) as a share of exports in the year of the peak (trough) of the cycle The amplitude of the capital flow bonanza (bust) as a share of exports is shown on the horizontal axis. Each capital flow bonanza (bust) is identified on the vertical axis with the name of the country and the year of the peak of the capital flow cycle. The bottom table shows the average amplitude of capital flow bonanzas (busts) during systemic and idiosyncratic capital flow cycles in the first and second episode of financial

globalization. The test statistics in this table shows the one-tailed p-value at which the Null Hypothesis of equality of capital flow bonanzas (busts) during systemic and idiosyncratic capital flow cycles for each episode of financial globalization can be rejected. 
Figure VII

Frequency Distribution of International Issuance/Exports
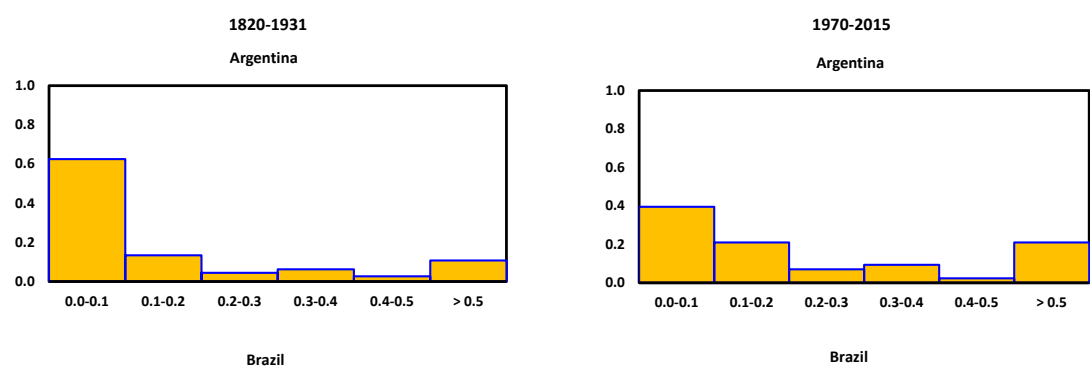

KS test p-value: 0.08
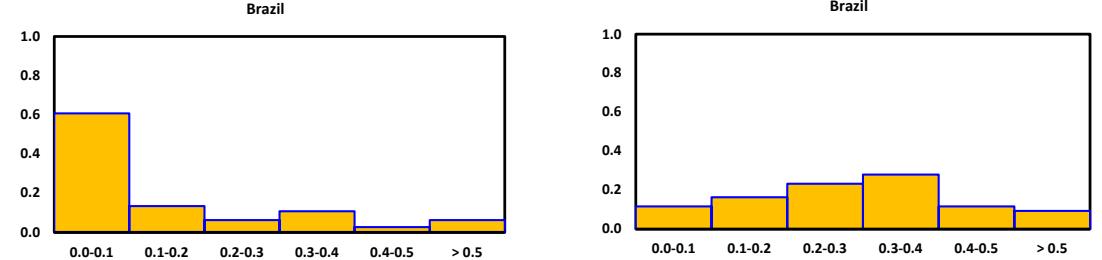

KS test p-value: 0.00

Chile

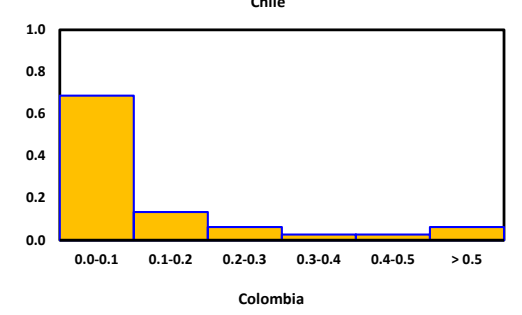

Chile

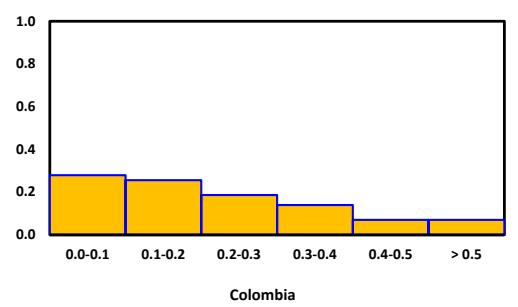

KS test p-value: 0.00

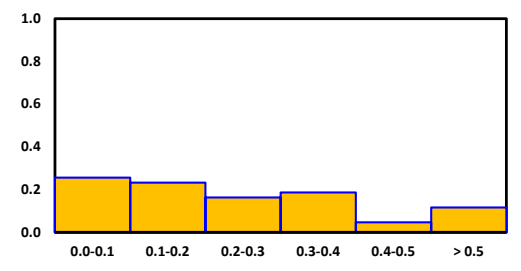

KS test p-value: 0.00
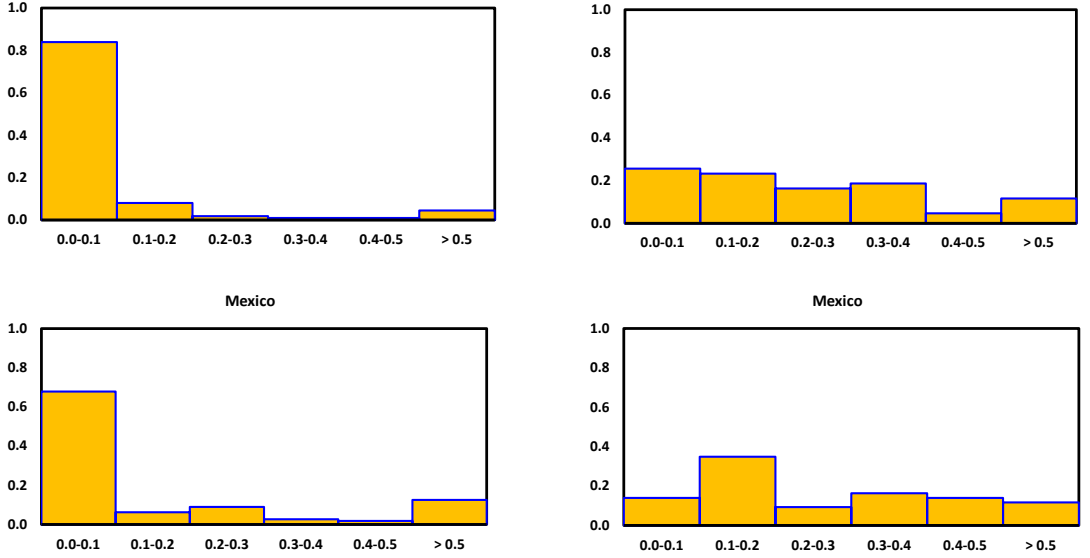

KS test p-value: 0.00

Peru
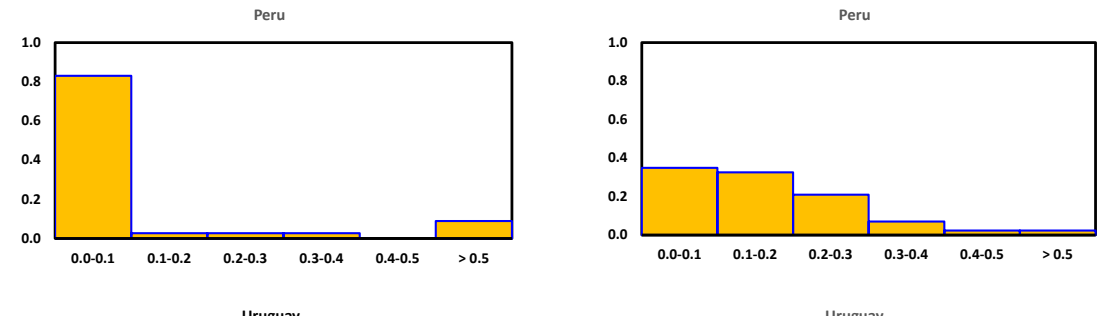

KS test p-value: 0.00
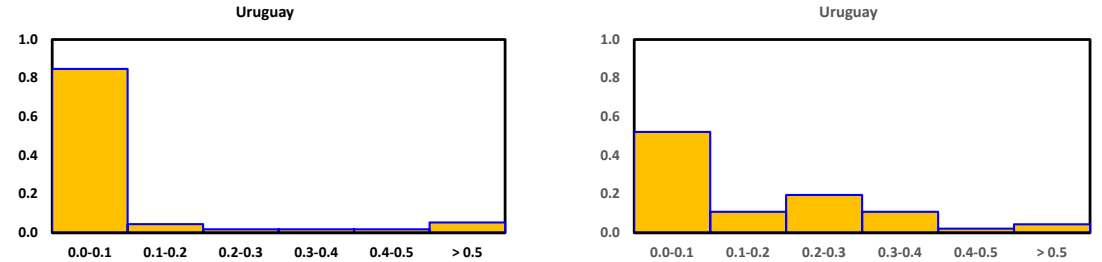

KS test $p$-value: $\mathbf{0 . 0 0}$

Notes: This figure shows the histogram of gross international issuance (as a share of exports) of each country in both episodes of financial globalization. The Kolmogorov-Smirnov test is a nonparametric test of the equality of probability distributions. The KS test p-values at the right of each country histograms show the p-values at which the Null Hypothesis of equality of the distributions during the first and second episode of financial globalization can be rejected. 
Figure VIII

The Pull Factors

Exports and Terms of Trade

1820-1931
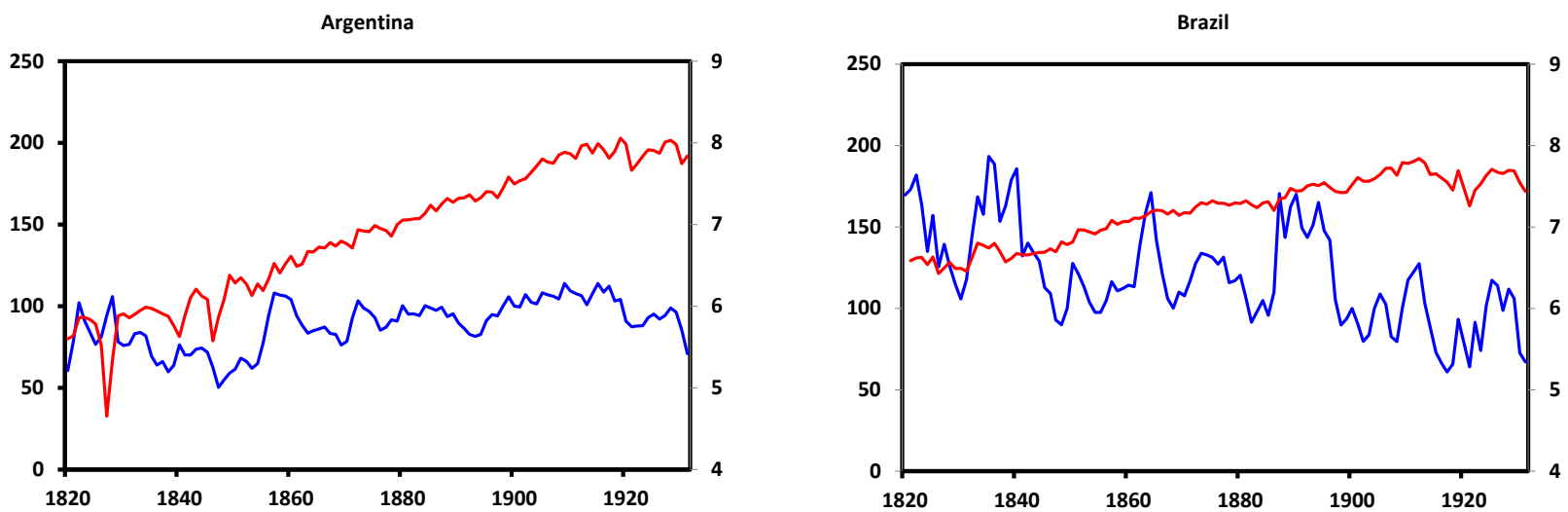

Chile

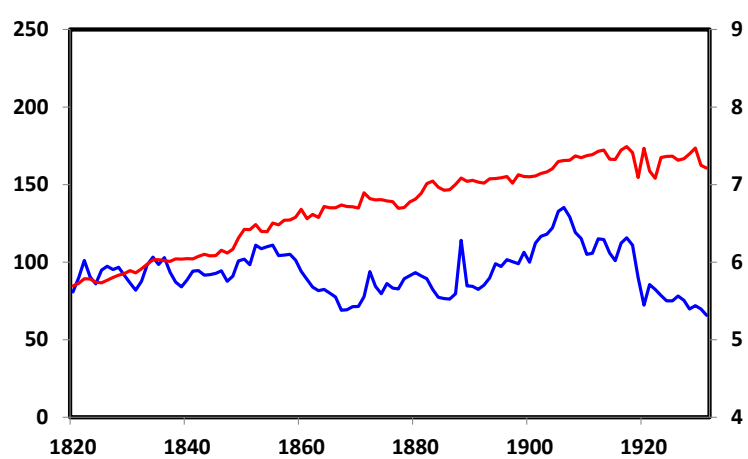

Colombia

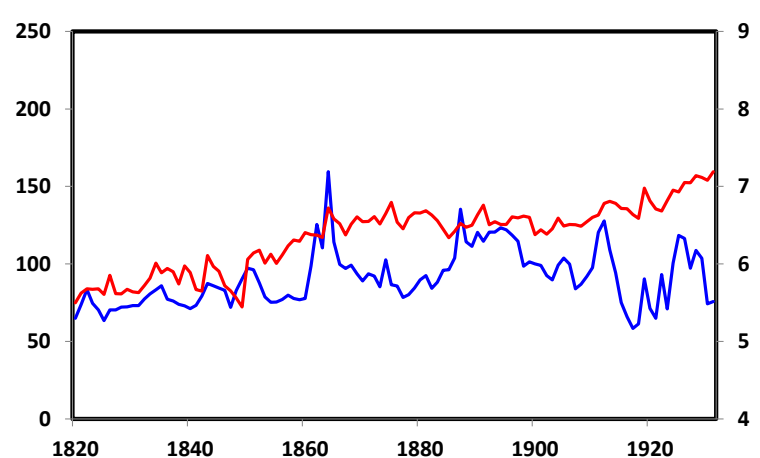

Mexico
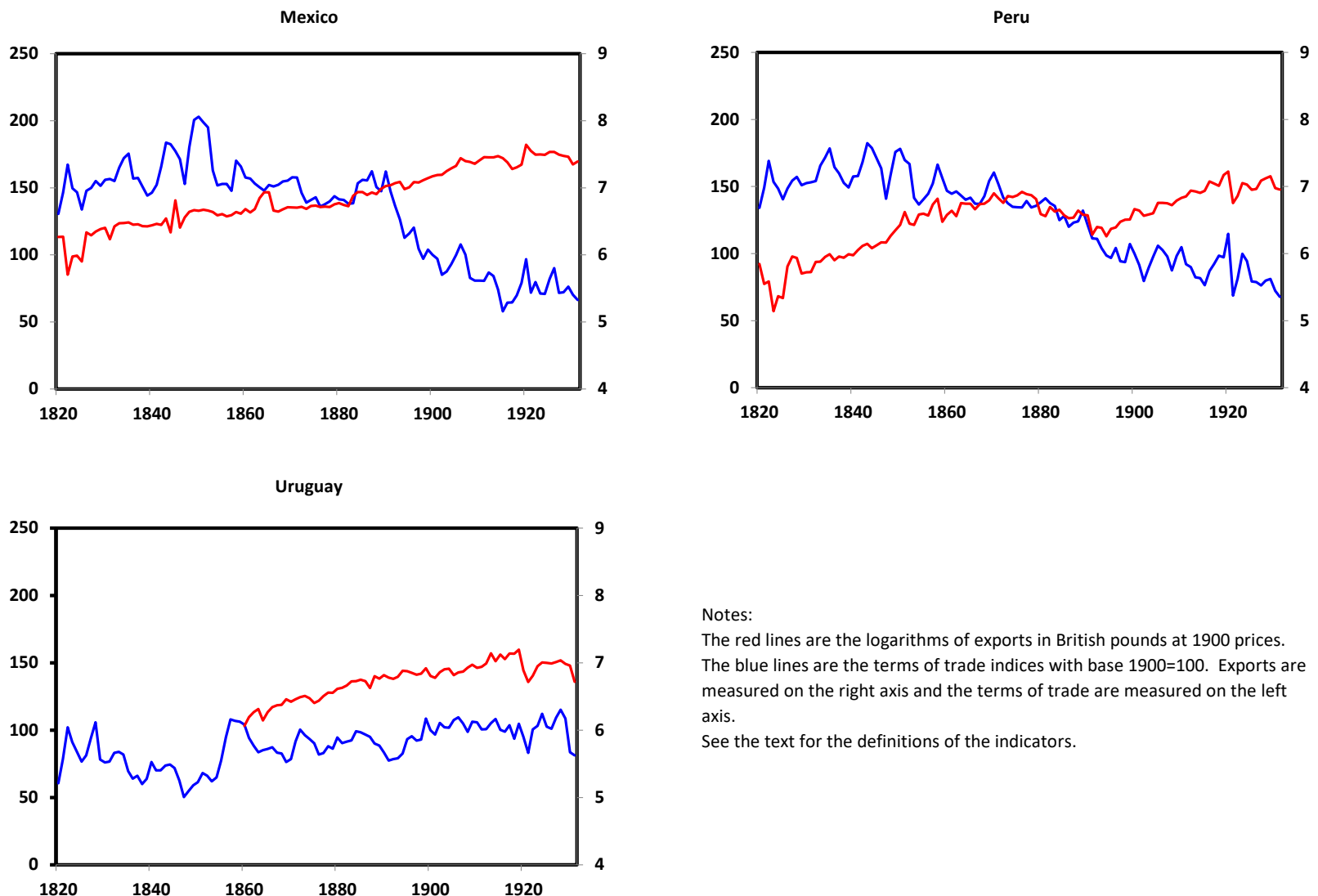

Notes:

The red lines are the logarithms of exports in British pounds at 1900 prices.

The blue lines are the terms of trade indices with base 1900=100. Exports are measured on the right axis and the terms of trade are measured on the left axis.

See the text for the definitions of the indicators. 
Figure VIII

The Pull Factors

Exports and Terms of Trade

1970-2015
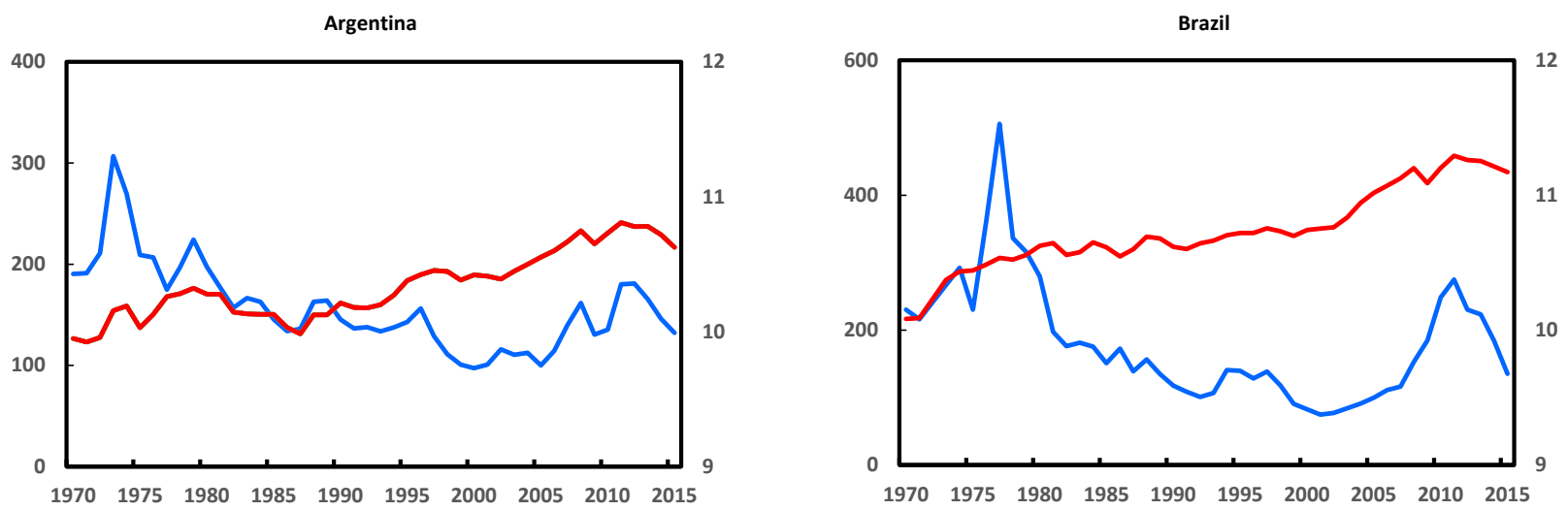

Chile
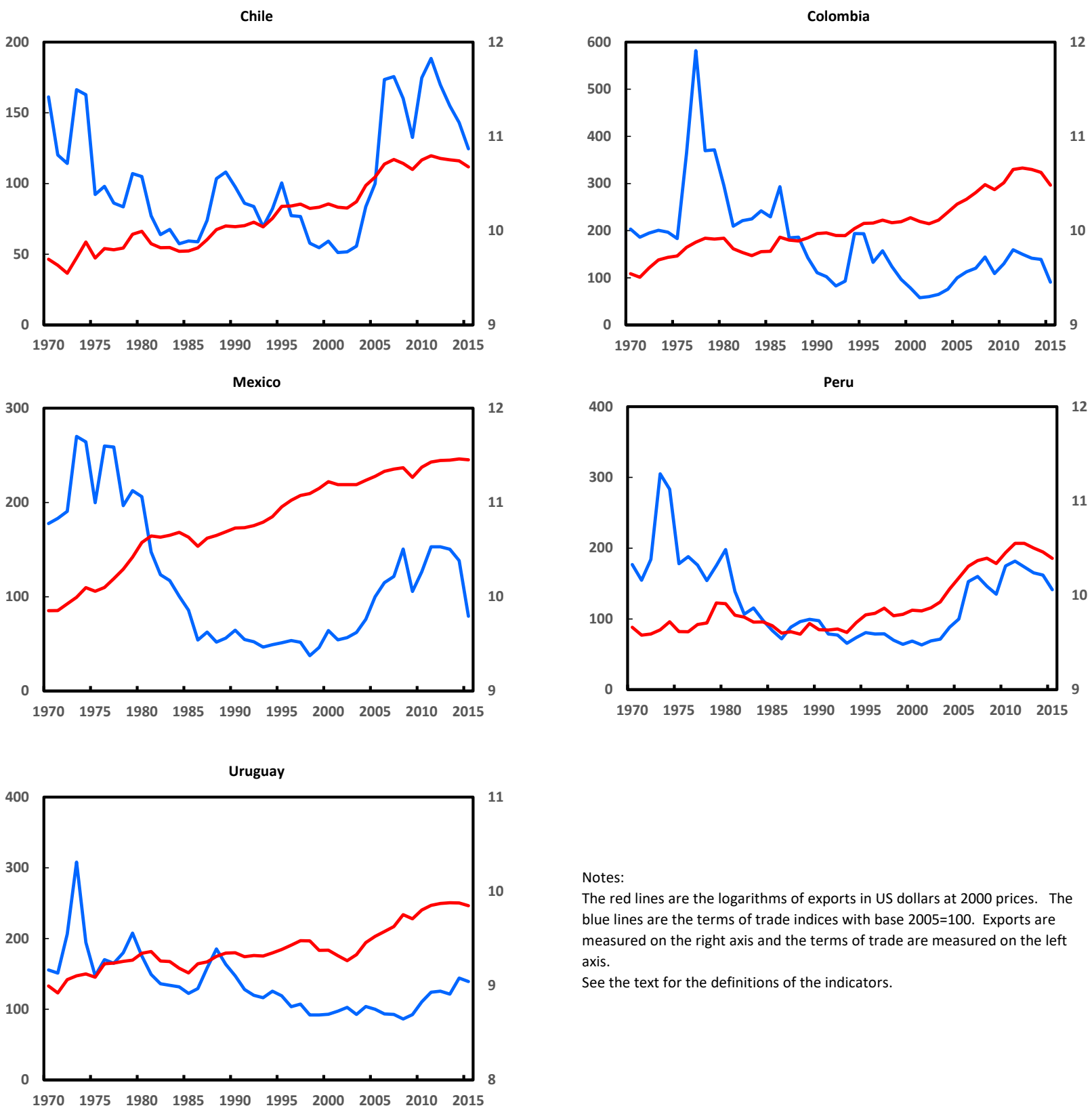

Notes:

The red lines are the logarithms of exports in US dollars at 2000 prices. The blue lines are the terms of trade indices with base $2005=100$. Exports are measured on the right axis and the terms of trade are measured on the left axis.

See the text for the definitions of the indicators. 
Figure IX

The Push Factors

1820-1931

\section{U.K. Short-Term Interest Rate}

(in Percent per Annum )

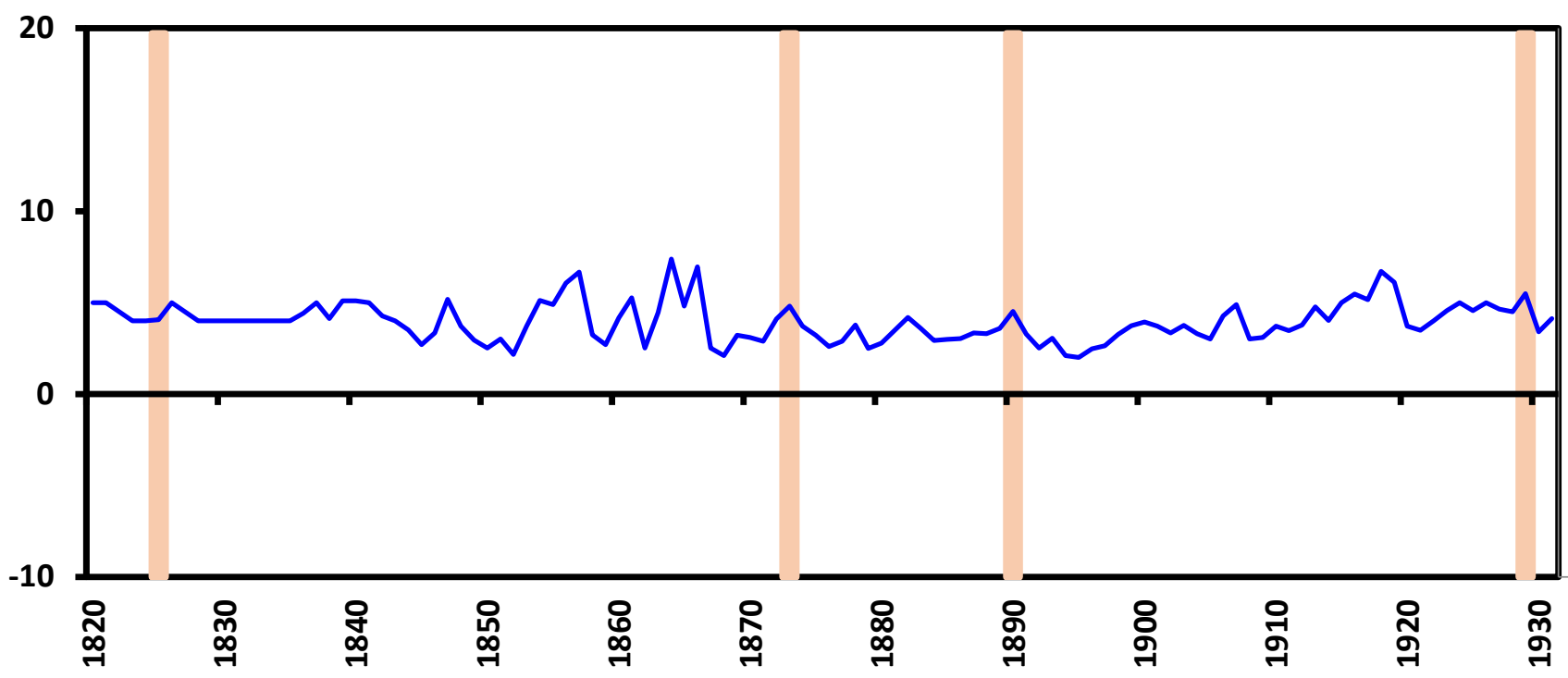

World Imports

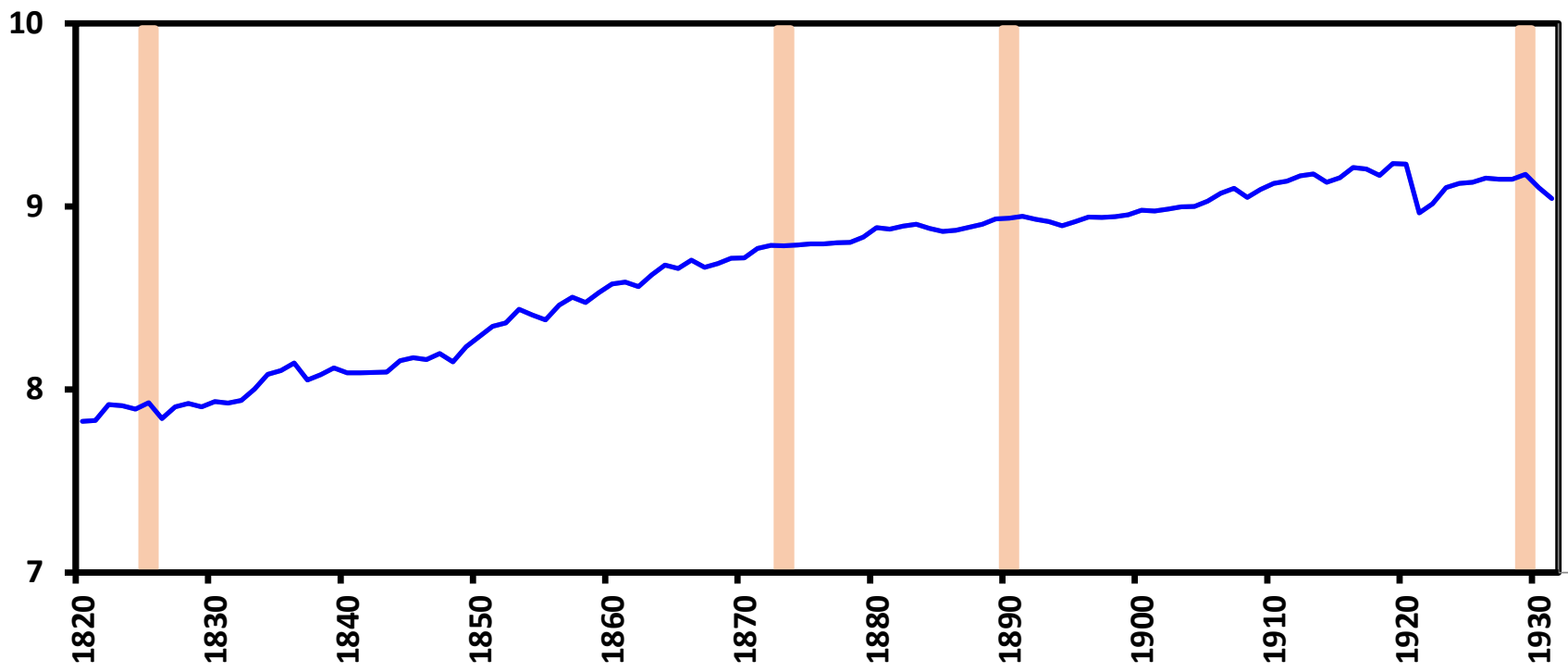

Notes: The U.K. short-term interest rate is the Bank rate. World imports in the bottom panel are the imports of France, the United Kingdom, and the United States in British pounds at 1900 prices (in logarithms). The vertical lines identify the years of crisis (beginning) in the financial center. See the text for the definitions of the indicators. 
Figure IX

The Push Factors

1970-2015

\section{U.S. Short Term Interest Rate}

(Percent Per Annum)

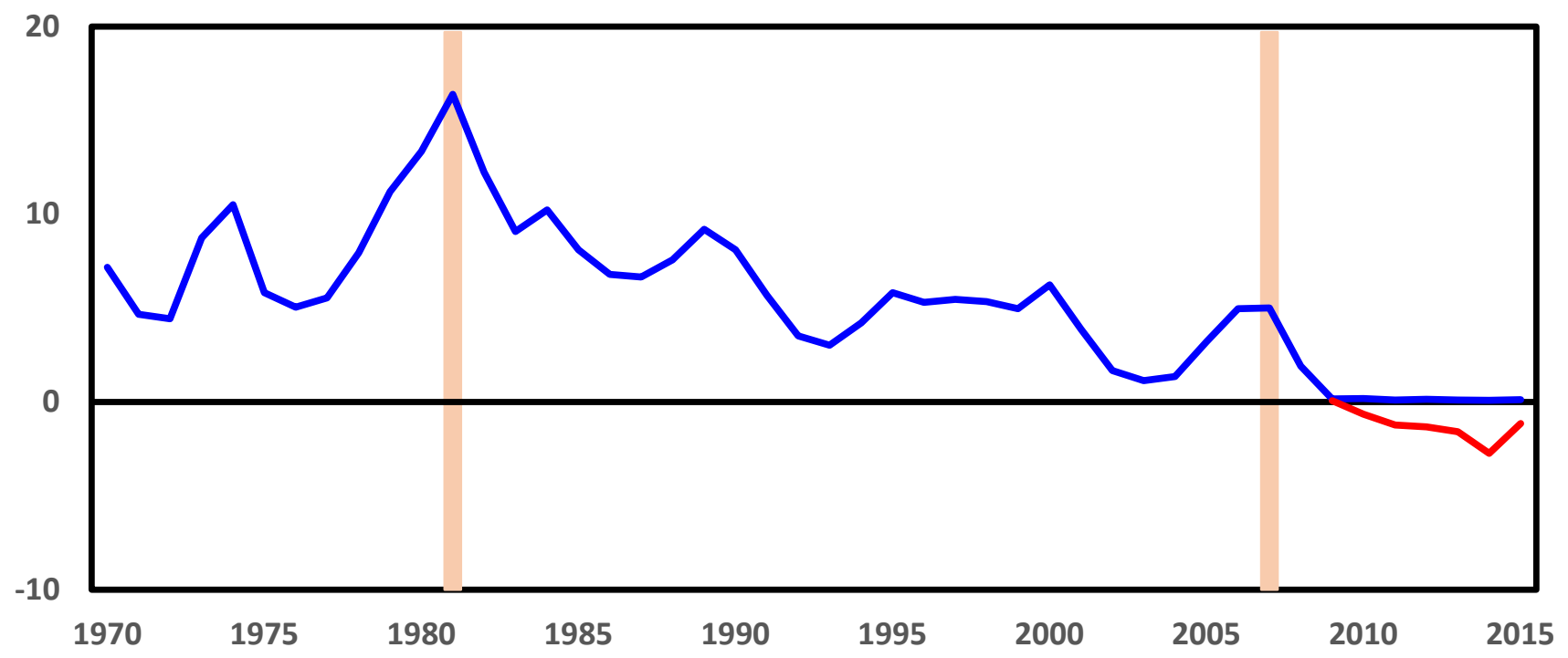

World Imports

13

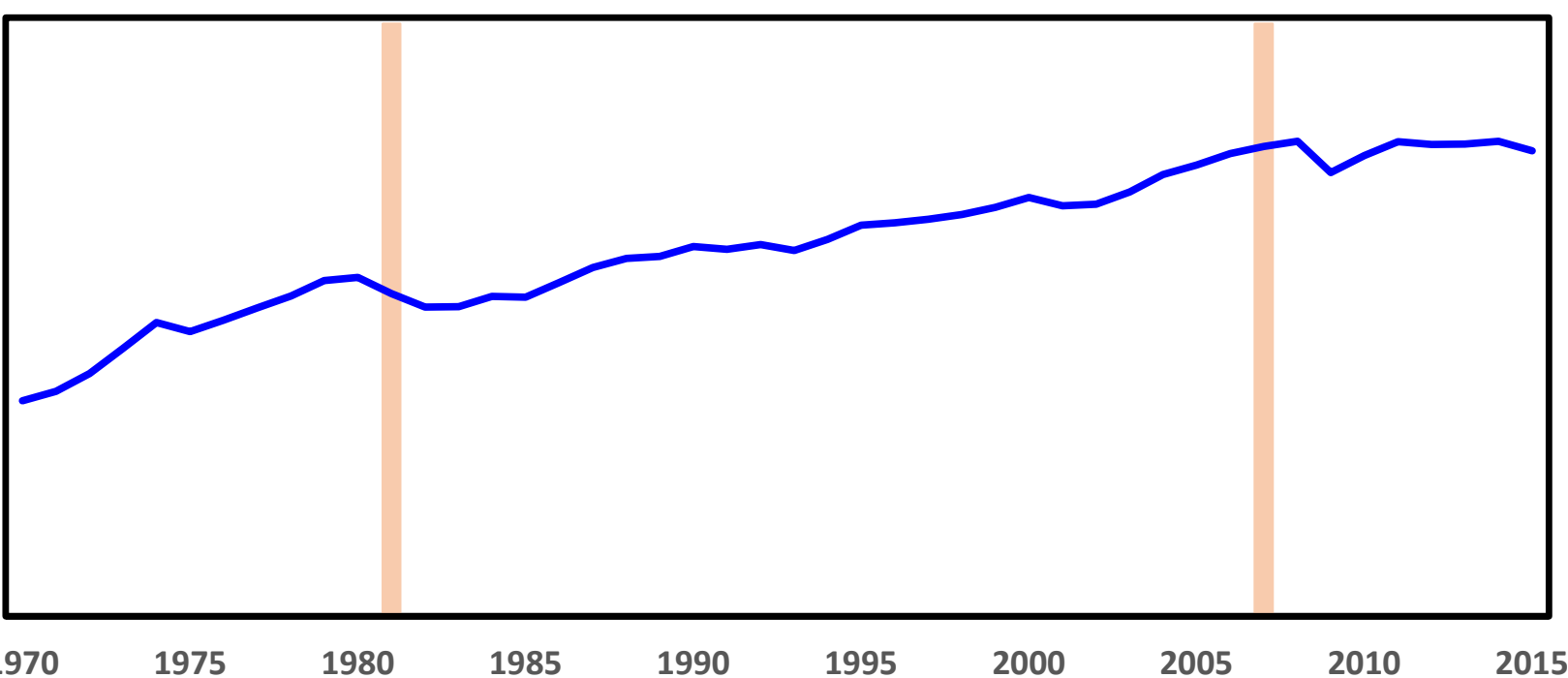

Notes: The U.S. short-term interest rate is the federal funds rate. The blue line is the effective federal funds rate while the red line shows the Wu and Xia (2016) shadow federal funds rate for the zero-lower-bound episode.

World imports in the bottom panel are the imports of Germany, the United Kingdom, and the United States in U.S. dollars at 2000 prices (in logarithms). The vertical lines identify the years of crisis (beginning) in the financial center. See the text for the definitions of the indicators. 
Figure $X$

Capital Flow Cycles and the Pull Factors during Idiosyncratic and Systemic Capital Flow Episodes

Idiosyncratic Episodes 1820-1931

Latin American International Issuance/Exports

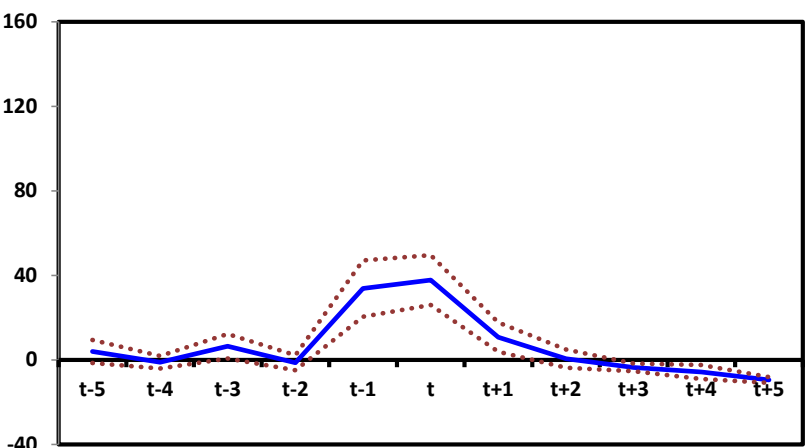

Exports Growth Rate

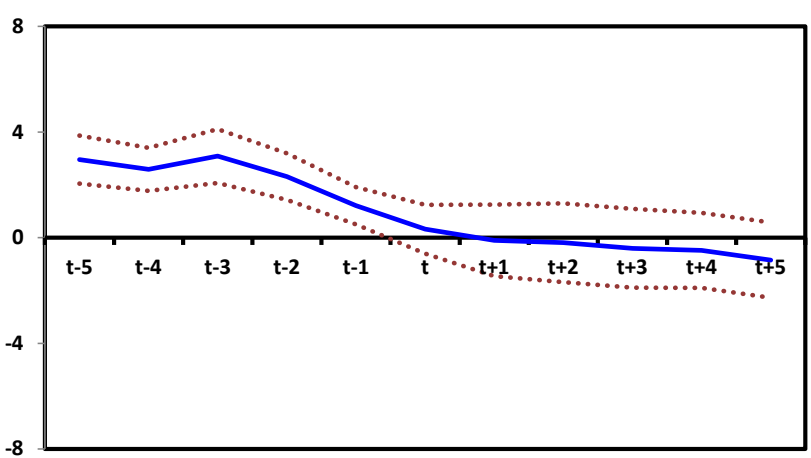

Tems of Trade Growth Rate

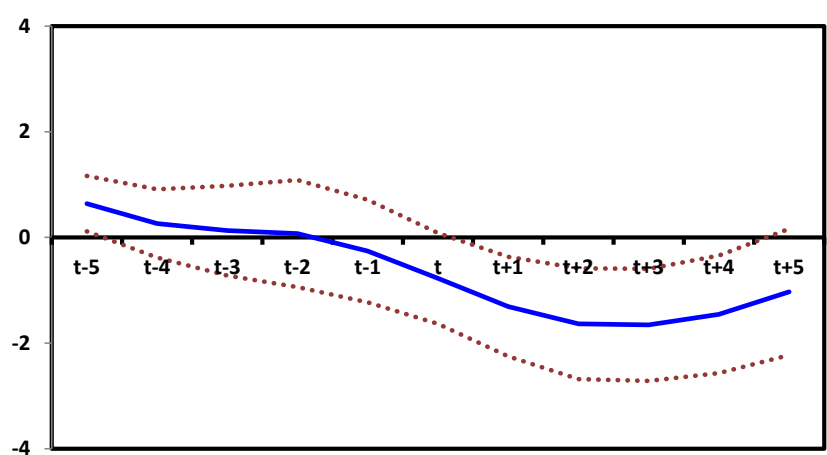

Systemic Episodes

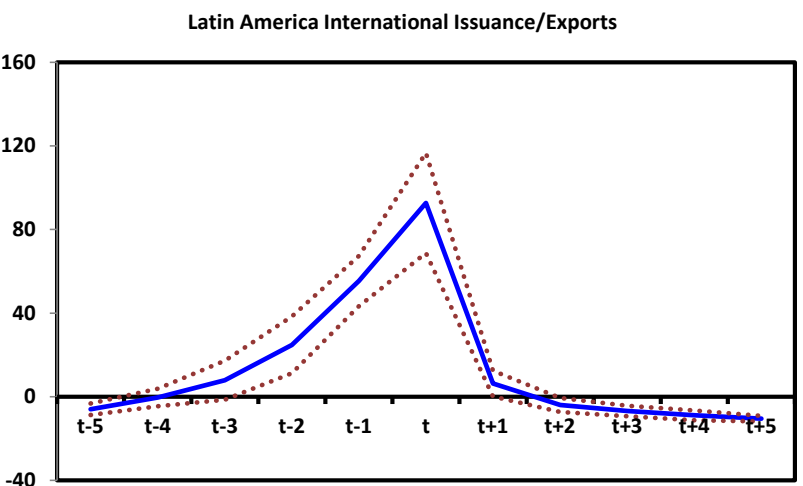

Exports Growth Rate

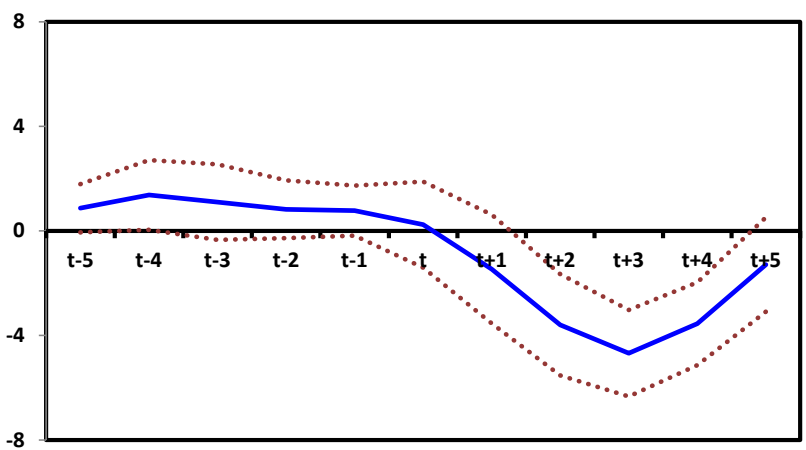

Terms of Trade Growth Rate

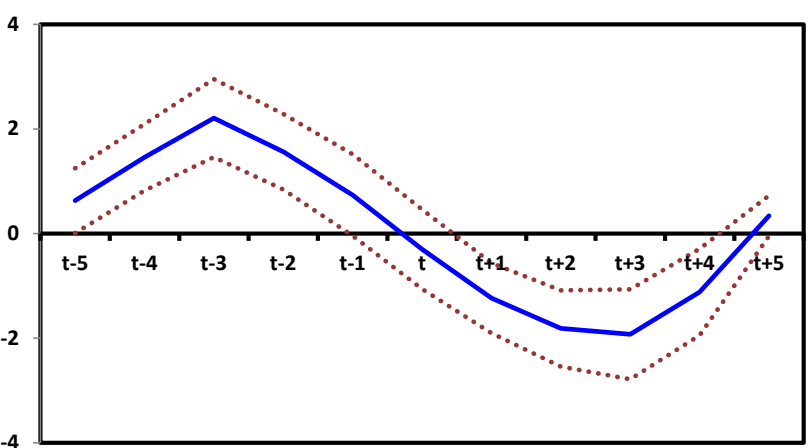

Notes: Latin American countries international issuance is shown as a percent of exports. The growth rate of exports is the growth rate of trend real exports. The growth rate of the terms of trade is the growth rate of trend terms of trade. The three indicators are shown relative to their sample average (in percentage points). Year $t$ is the year of the peak of the cycle. The solid line is the average behavior of each indicator across all cycles. The dotted lines are the plus/minus one-standard error bands around the average. See the text for the definitions of the indicators. 
Figure $X$

Capital Flow Cycles and the Pull Factors during Idiosyncratic and Systemic Capital Flow Episodes

Idiosyncratic Episodes

International Issuance/Exports
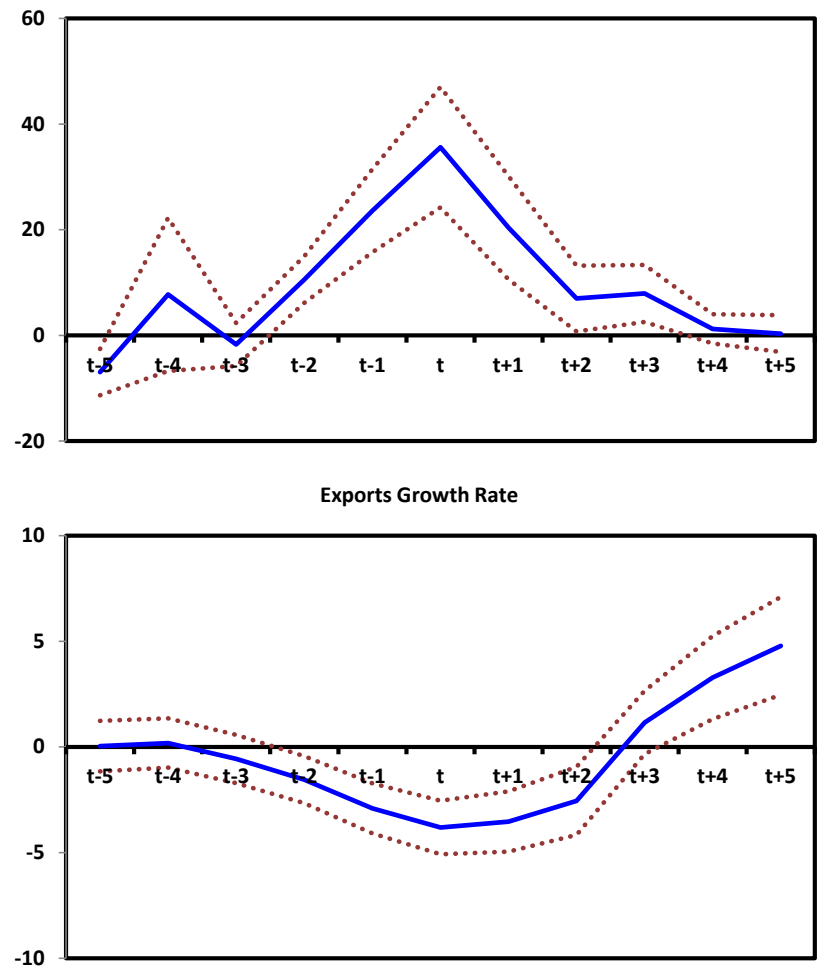

Terms of Trade Growth Rate

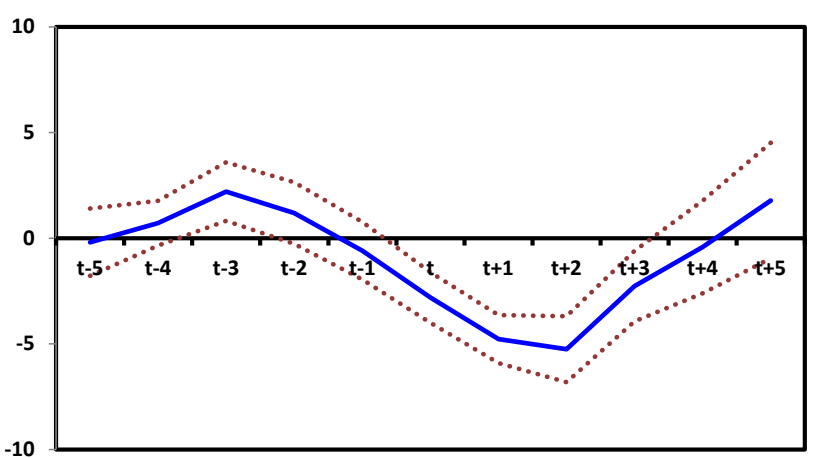

Systemic Episodes

International Issuance/Exports
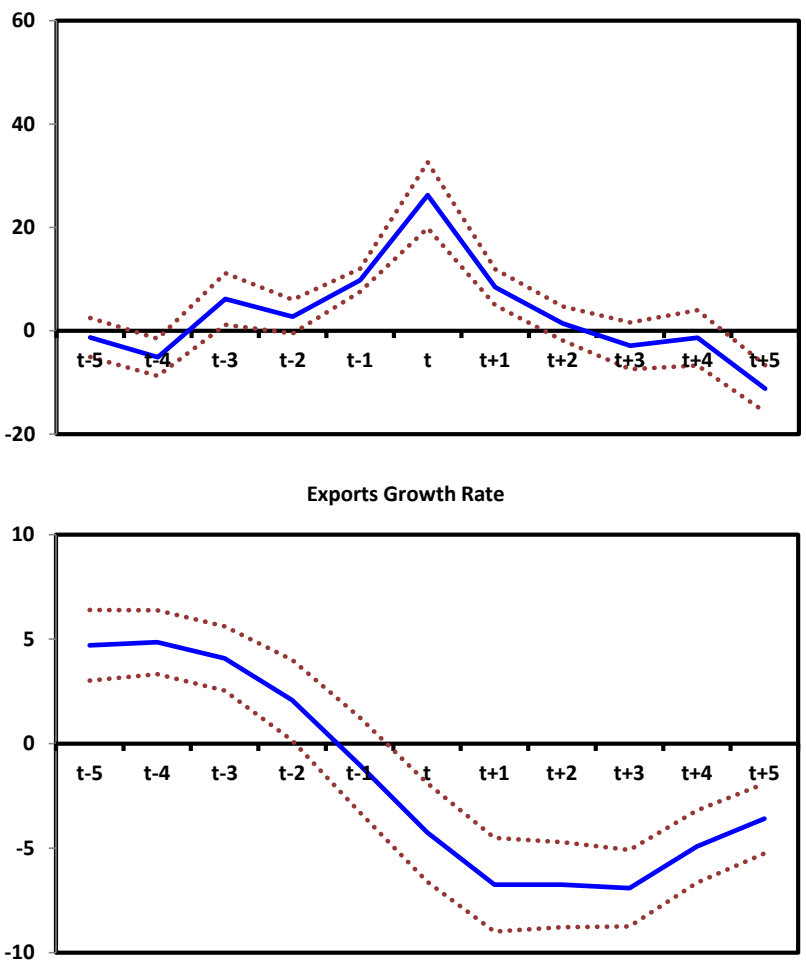

Terms of Trade Growth Rate

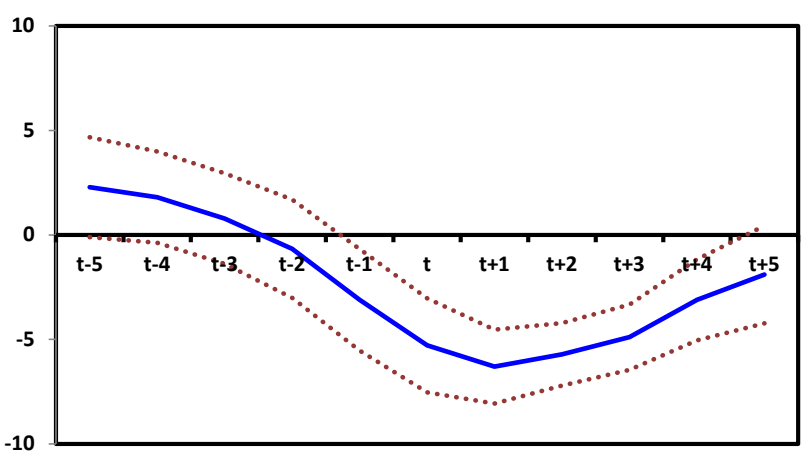

Notes: Latin American countries international issuance is shown as a percent of exports. The growth rate of exports is the growth rate of trend real exports. The growth rate of the terms of trade is the growth rate of trend terms of trade. The three indicators are shown relative to their sample average (in percentage points). Year $t$ is the year of the peak of the cycle. The solid line is the average behavior of each indicator across all cycles. The dotted lines are the plus/minus one-standard error bands around the average. See the text for the definitions of the indicators. 
Figure XI

The Push Factors during Idiosyncratic and Systemic Capital Flow Episodes 1820-1931

Idiosyncratic Episodes

U.K. Interest Rate

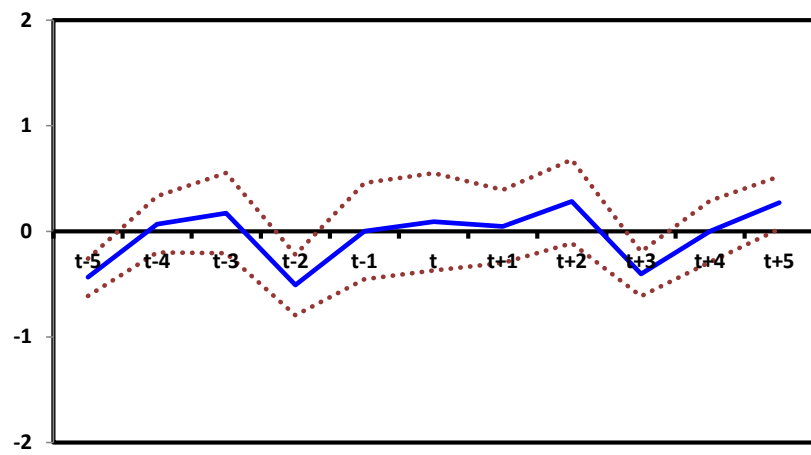

Percent Change in the U.K. Interest Rate

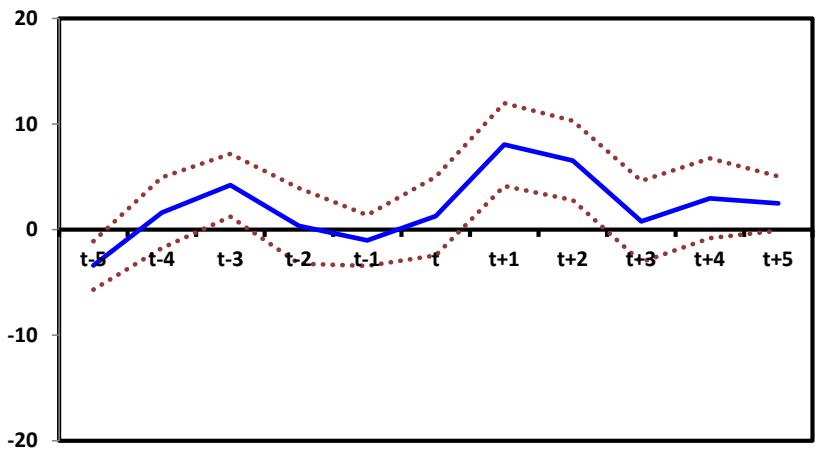

World Imports Growth Rate

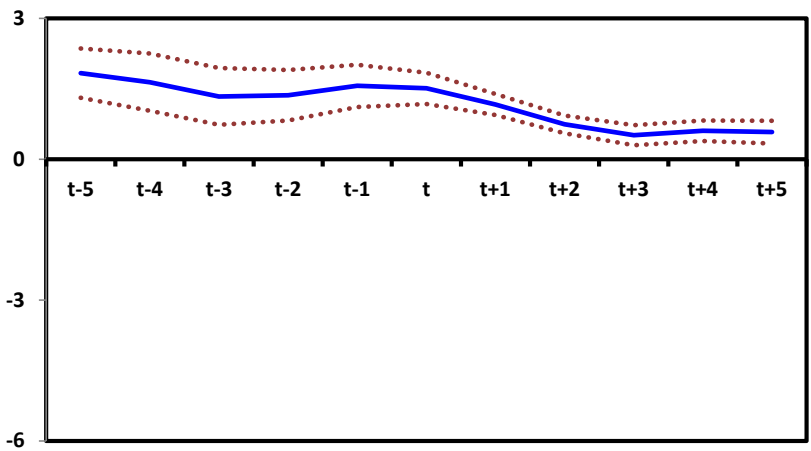

Systemic Episodes

U.K. Interest Rate

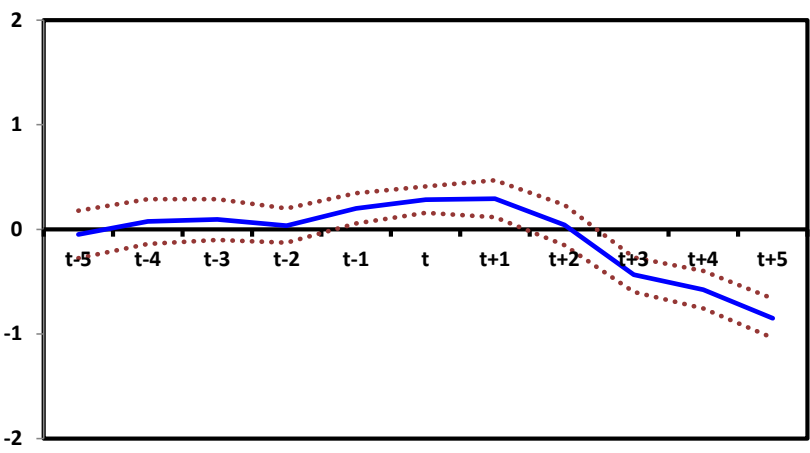

Percent Change in the U.K. Interest Rate
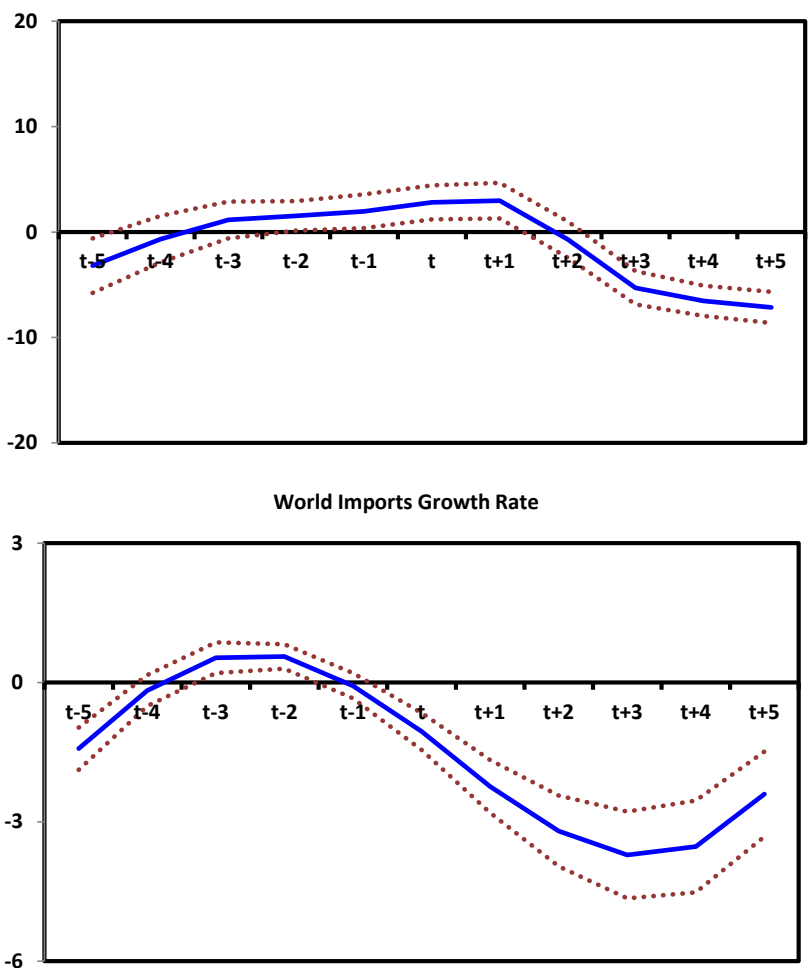

Notes: The U.K. interest rate is the Bank rate. The Percent Change in the U.K. Interest Rate is the three-year percent change in the UK interest rate in percent per annum. World imports in the bottom panel are the imports of France, the United Kingdom, and the United States in British pounds in 1900 prices. The growth rate of World Imports is the growth rate of the trend. The U.K Interest rate and world imports growth rate are shown relative to their sample average. These two panels are in in percentage points. Year $t$ is the year of the peak of the cycle. The solid line is the average behavior of each indicator across all cyles. The dotted lines are the plus/minus one-standard error bands around the average. 
Figure XI

The Push Factors during Idiosyncratic and Systemic Capital Flow Episodes 1970-2015

Idiosyncratic Episodes

U.S. Interest Rate

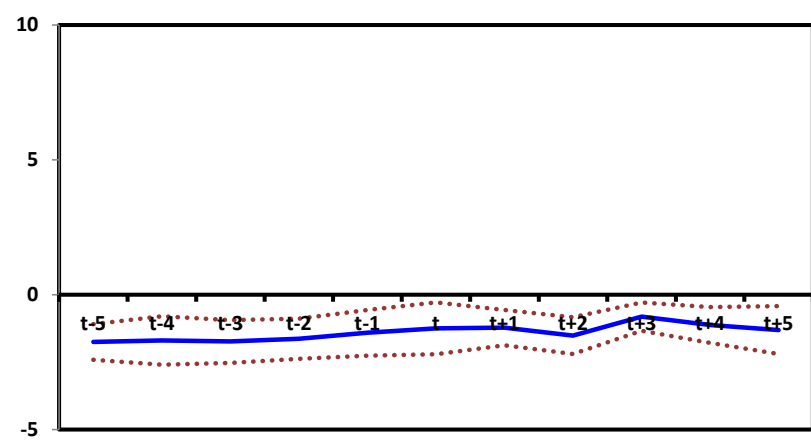

Percent Change in the U.S. Interest Rate
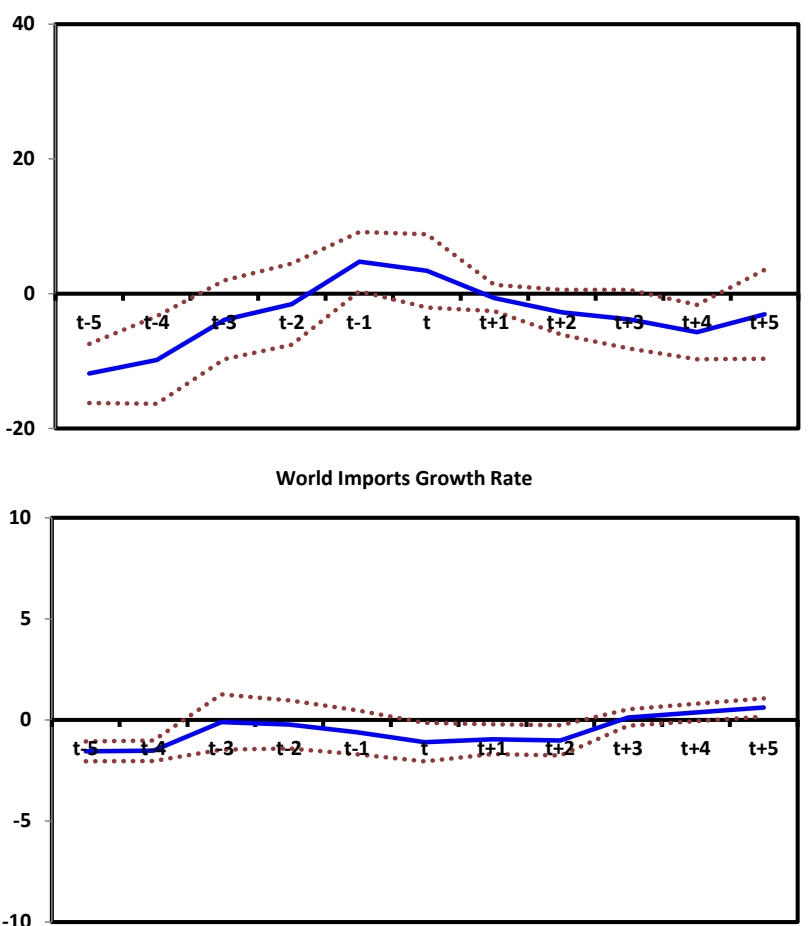

Systemic Episodes

U.S. Interest Rate

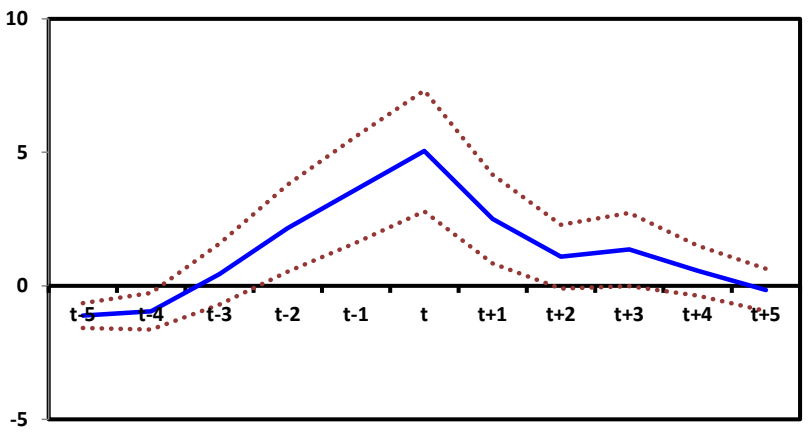

Percent Change in the U.S. Interest Rate

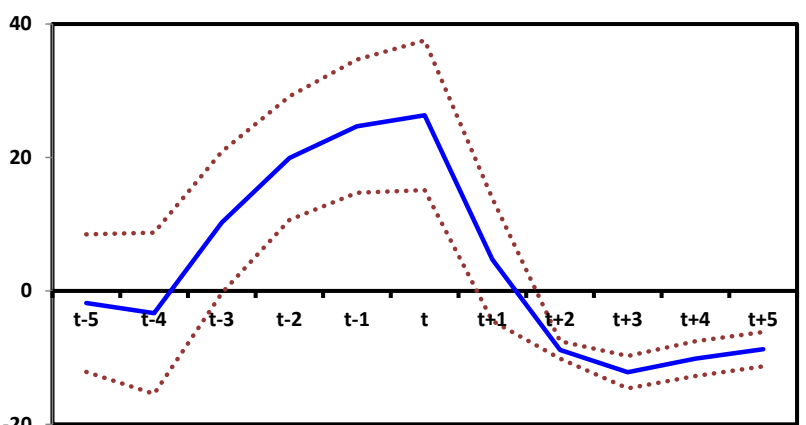

World Imports Growth Rate

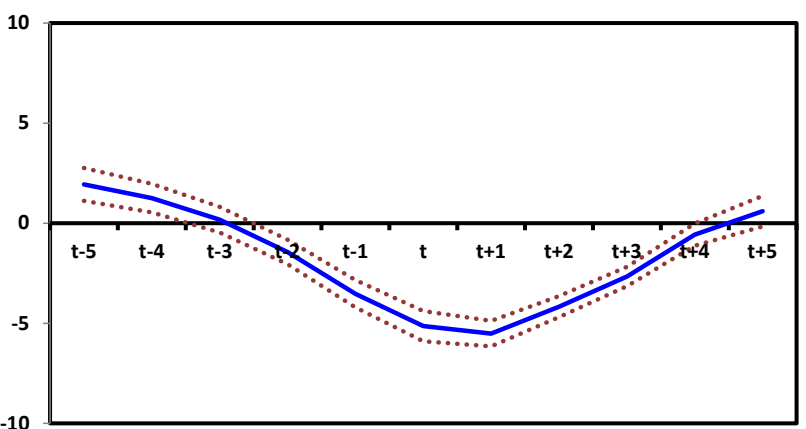

Notes: The U.S. interest rate is the Federal Funds rate. The Percent Change in the U.S. Interest Rate is three-year percent change in the U.S. interest rate in percent per annum. World imports in the bottom panel are the imports of Germany, the United Kingdom, and the United States in U.S. dollars in 2000 prices. The growth rate of World Imports is the growth rate of the trend. The U.S Interest Rate and World Imports growth rate are shown relative to their sample average. These two panels are in percentage points. Year $t$ is the year of the peak of the cycle. The solid line is the average behavior of each indicator across all cyles. The dotted lines are the plus/minus one-standard error bands around the average. 